UNIVERSIDADE DE SÃO PAULO

INSTITUTO DE PSICOLOGIA

TATIANA MALHEIROS ASSUMPÇÃO

Avaliação do perfil psiquiátrico de pacientes com mucopolissacaridoses

São Paulo

2013 
TATIANA MALHEIROS ASSUMPÇÃO

\title{
Avaliação do perfil psiquiátrico de pacientes com mucopolissacaridoses
}

\author{
(Versão original)
}

Dissertação apresentada ao Instituto de

Psicologia da Universidade de São Paulo, para obtenção do título de Mestre em Psicologia.

São Paulo

2013 


\section{AUTORIZO A REPRODUÇÃO E DIVULGAÇÃO TOTAL OU PARCIAL DESTE TRABALHO, POR QUALQUER MEIO CONVENCIONAL OU ELETRÔNICO, PARA FINS DE ESTUDO E PESQUISA, DESDE QUE CITADA A FONTE.}

Catalogação na publicação

Biblioteca Dante Moreira Leite

Instituto de Psicologia da Universidade de São Paulo

Assumpção, Tatiana Malheiros.

Avaliação do perfil psiquiátrico de pacientes com mucopolissacaridoses / Tatiana Malheiros Assumpção; orientador Andrés Eduardo Aguirre Antúnez. -- São Paulo, 2013.

$144 \mathrm{f}$.

Dissertação (Mestrado - Programa de Pós-Graduação em Psicologia. Área de Concentração: Psicologia Clinica) - Instituto de Psicologia da Universidade de São Paulo.

1. Doenças genéticas 2. Erros inatos do metabolismo 3. Transtornos mentais 4. Distúrbios do desenvolvimento 5. Genética do comportamento I. Título.

RB155.5 
Para meu pai, que me iniciou no caminho da Psiquiatria Infantil. 


\section{Agradecimentos:}

Ao meu marido, Álvaro, por não permitir que eu desanimasse. Obrigada por acreditar em mim, às vezes mais do que eu mesma.

À minha filha, Helena, pelos momentos roubados e pelo amor incondicional.

À minha mãe, Regina, que me deu um parâmetro de realidade quando eu o esquecia.

À minha irmã, Thais, pela paciência para me ouvir nos momentos de crise.

Ao professor doutor Andrés Eduardo Aguirre Antúnez, por ter me acolhido em um momento de incerteza.

À professora doutora Chong Ae Kim, pela gentileza com que me recebeu e pela ajuda em reunir este grupo de pacientes.

Ao doutor Felipe Borlot, por compartilhar seus dados sobre o comprometimento neurológico de alguns pacientes em comum.

Às amigas do Projeto Distúrbios do Desenvolvimento, Melanie, Milena, Marília e Alessandra, pelo apoio e companhia neste caminho.

À Maria Lucineide, por tomar conta de tudo enquanto eu não estava disponível.

Aos pacientes e seus familiares, que concordaram em partilhar um pouco de sua história para a realização deste trabalho. 
"Toda criança do mundo

Deve ser bem protegida

Contra os rigores do tempo

Contra os rigores da vida.

Criança tem que ter nome

Criança tem que ter lar

Ter saúde e não ter fome

Ter segurança e estudar.

Não é questão de querer

Nem questão de concordar

Os direitos das crianças

Todos têm de respeitar.

\section{$(\ldots)$}

A criança tem direito

Até de ser diferente.

E tem que ser bem aceita

Seja sadia ou doente."

Os direitos das crianças segundo Ruth Rocha 


\section{Resumo}

As mucopolissacaridoses (MPS) são um grupo de doenças metabólicas hereditárias causadas pela deficiência de enzimas lisossomais específicas, que causam alterações físicas e/ou comportamentais crônicas e progressivas. Um fenótipo comportamental é um padrão característico de observações motoras, cognitivas, linguísticas e sociais consistentemente associado a uma condição biológica. Tal fenótipo pode ser um transtorno mental ou outras características de comportamento não necessariamente associadas a transtornos. No caso específico das mucopolissacaridoses, embora haja diversos relatos na literatura sobre as altas taxas de ocorrência de problemas de comportamento na síndrome de Sanfilippo (MPS III), muito pouco é conhecido sobre as características comportamentais das outras entidades (MPS I, II, IV, VI e VII). Este trabalho pretendeu avaliar e descrever as alterações psiquiátricas encontradas em 22 pacientes com MPS atendidos em três serviços de genética clínica (4 MPS I, 5 MPS II, 1 MPS III, 4 MPS IV, 7 MPS VI, 1 MPS VII). As avaliações foram feitas através de instrumentos específicos, traduzidos e validados para nossa população, a saber: K-SADS PL, ATA, CARS, CGAS; e um instrumento traduzido, mas ainda sem validação brasileira: Escalas de Comportamento Adaptativo de Vineland. Os resultados mostraram que esses indivíduos apresentam altas taxas de transtornos mentais ao longo da vida, comportamento adaptativo deficitário e funcionamento global prejudicado. Além disso, observou-se um grande impacto familiar da doença, abandono escolar por falta de condições de acesso e de preparo da própria escola, grande dependência dos indivíduos avaliados e sobrecarga de um único cuidador, geralmente a mãe. Também ficou evidente o peso trazido pelo próprio tratamento, traduzido em uma recusa em aceitar novas propostas clínicas oferecidas. Concluiu-se que a população estudada é altamente vulnerável dos pontos de vista pessoal, familiar e social, sendo necessários mais estudos para seu melhor conhecimento e elaboração de programas e políticas de atendimento mais direcionados para suas necessidades.

Palavras-chave: doenças genéticas inatas, mucopolissacaridoses, transtornos mentais, transtornos do desenvolvimento infantil, genética comportamental. 


\begin{abstract}
Mucopolysaccharidoses (MPS) are a group of hereditary metabolic diseases caused by deficient lysossomal enzymes, that lead to progressive physic and/or behavioral abnormalities. A behavioral phenotype is a characteristic pattern of motor, cognitive, linguistic and social observations, consistently associated to a biological condition. That phenotype may be a mental disorder or other behavioral characteristics not necessarily associated to any specific disorder. Referring to MPS, altohugh there are several descriptions of high ocurrence of behavioral problems in patients with Sanfilippo Syndrome (MPS III), the knowledge about behavioral characteristics of the other types of MPS is scarce. This work intended to analyse and describe psychiatric alterations in 22 patients with MPS from three services of medical genetics. Evaluation was made using specific instruments, translated and validated for use with brazilian population: K-SADS-PL, ATA, CARS, CGAS; and one instrument translated but not validated for brazilian population: Vineland Adaptive Behavior Scales. Results showed high lifetime prevalence of mental disorders, deficient adaptive behavior, and poor global functioning. Besides, it was observed intense familiar impact, high drop out rates from school, highly dependent individuals, and excessive burden for the caretaker. It was also evidenced the burden of the treatment itself. The conclusion was that this population is extremely vulnerable, and that it is necessary the realization of more studies for the better understanding of its specific necessitites.
\end{abstract}

Key-words: inborn genetic diseases, mucopolysaccharidoses, mental disorders, developmental disabilities, behavioral genetics. 


\section{Glossário}

Áreas subendoteliais: área da parede dos vasos sanguíneos logo abaixo da camada mais interna de revestimento, chamada endotélio.

Cardiomiopatia: disfunção da musculatura cardíaca.

Cifose: deformidade da coluna cervical, comumente conhecida como corcunda.

Cor pulmonale: insuficiência cardíaca secundária a hipertensão na circulação pulmonar.

Dismorfismo: deformidade.

Displasia óssea: desenvolvimento anômalo dos ossos.

Enzimas: substâncias proteicas envolvidas em diversas fases do metabolismo celular.

Espondilolistese: deslizamento patológico de uma vértebra sobre outra.

Genu valgum: deformidade nos joelhos, levando as pernas a adquirirem o aspecto de um X.

Glicosaminoglicanos: substância participante da formação colágena dos tecidos conjuntivos.

Hepatoesplenomegalia: aumento volumétrico do fígado e do baço.

Lisossomo: organela intracelular responsável pelo armazenamento de substâncias.

Macrocefalia: aumento do perímetro cefálico.

Padrão de herança: modo de transmissão genética. Neste trabalho consideraremos apenas as características de herança monogênica, ou seja, que envolvem apenas um gene. Assim, recordando que nossa espécie possui todos os genes em duplicata, os modos de transmissão dos mesmos dependem do tipo de cromossomo em que eles se encontram e de sua capacidade ou não de se manifestarem se apenas uma cópia daquele alelo estiver presente.

Autossômico recessivo: tais genes encontram-se nos cromossomos não sexuais e é necessária a presença de dois alelos iguais para a manifestação do fenótipo.

Recessivo ligado ao X: tais genes encontram-se no cromossomo $\mathrm{X}$, sendo que o fenótipo se manifesta nos indivíduos do sexo masculino com apenas um alelo e, nos do sexo feminino, com os dois. No caso de doenças graves, as mulheres funcionam como portadoras e a doença é manifestada apenas pelos homens.

Pectus carinatum: deformidade do tórax caracterizada por região peitoral em forma de "quilha" ou ponta, como o peito de um pássaro. 
Pica: alteração no padrão alimentar caracterizada por ingestão repetida de substâncias não alimentares (por exemplo, barro ou pedaços de alvenaria).

Síndrome dismórfica: conjunto de deformidades comumente agrupadas.

Síndrome do túnel do carpo: síndrome dolorosa decorrente da compressão do nervo radial na região do pulso.

Tecido conjuntivo: tecido de sustentação, encontrado em todas as estruturas do organismo. 


\section{Medicações citadas}

Amlodipina: medicação anti-hipertensiva

Captopril: medicação anti-hipertensiva

Carvedilol: medicação anti-hipertensiva

Digoxina: medicação cardiotônica, utilizada em casos de insuficiência cardíaca

Enalapril: medicação anti-hipertensiva

Espironolactona: medicação diurética, utilizada no controle da hipertensão arterial sistêmica

Fenobarbital: medicação anticonvulsivante

Furosemida: medicação diurética, utilizada no controle da hipertensão arterial sistêmica

Marevan® (varfarina): medicação anticoagulante

Neuleptil® (periciazina): medicação neuroléptica

Risperidona: medicação neuroléptica 


\section{Sumário}

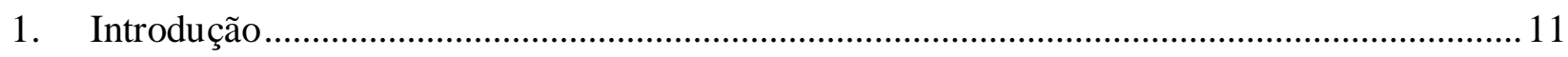

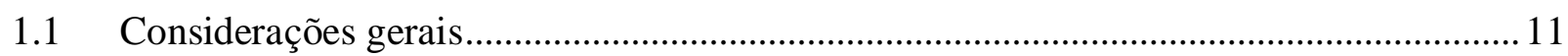

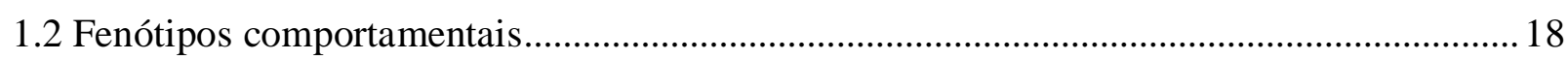

1.3 Manifestações comportamentais em pacientes com mucopolissacaridoses ............................20

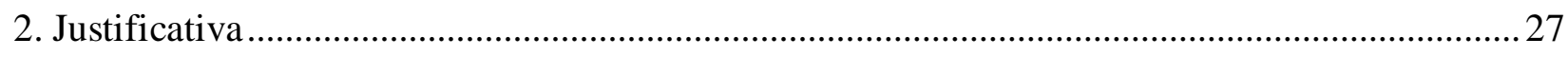

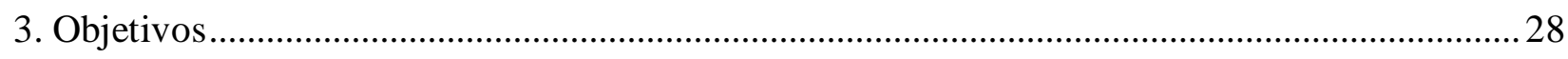

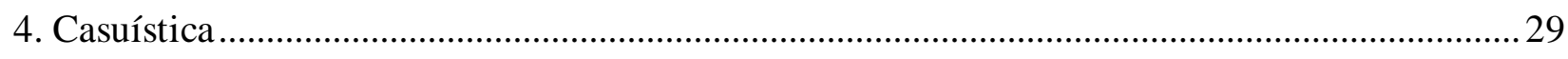

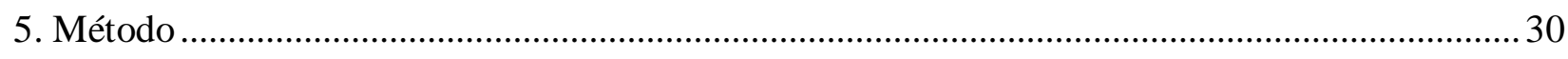

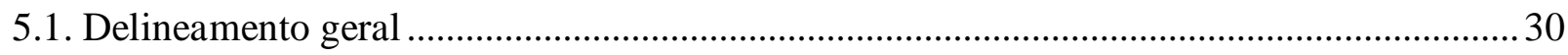

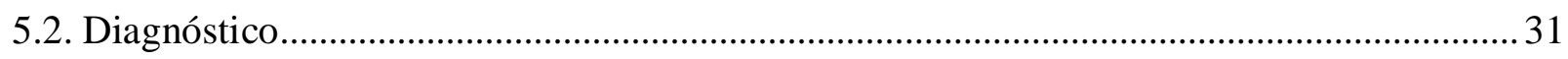

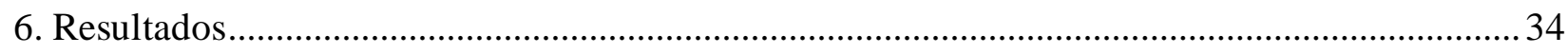

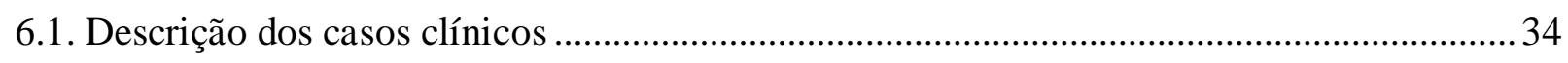

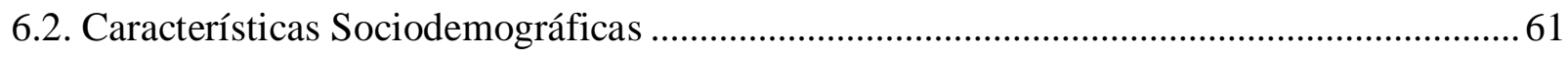

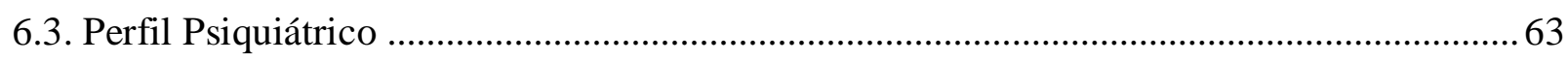

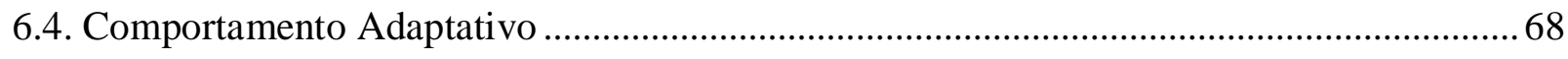

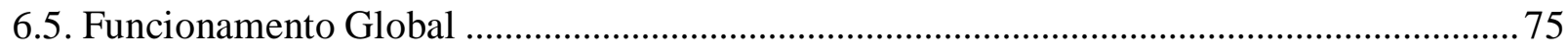

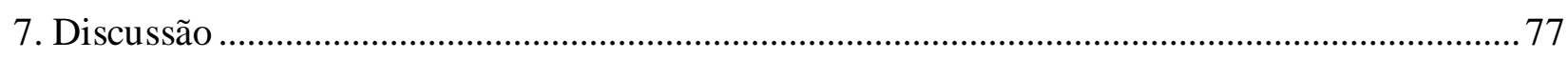

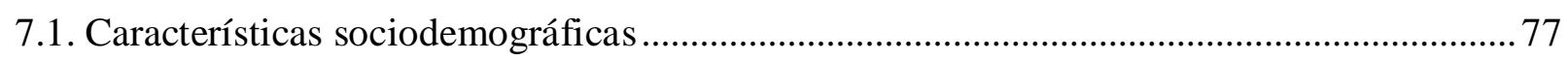

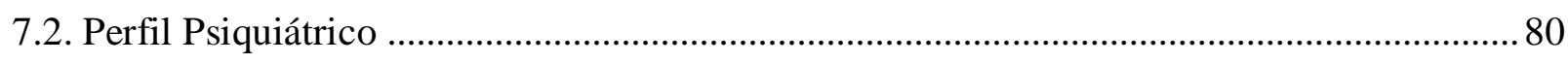

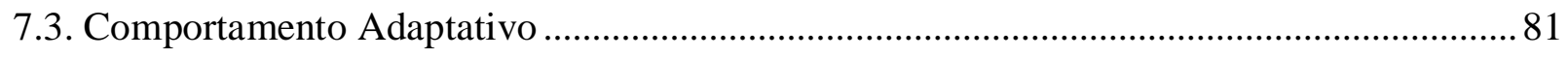

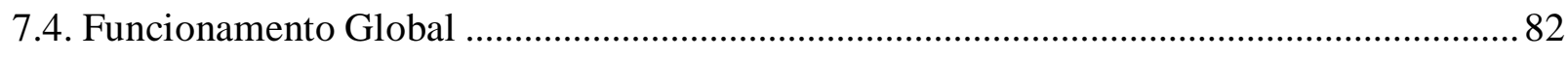

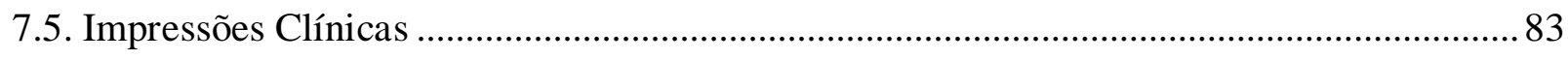

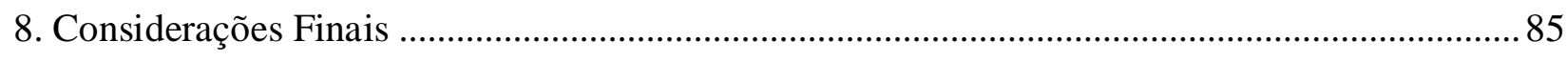

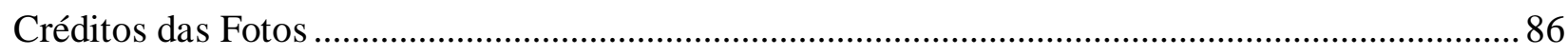

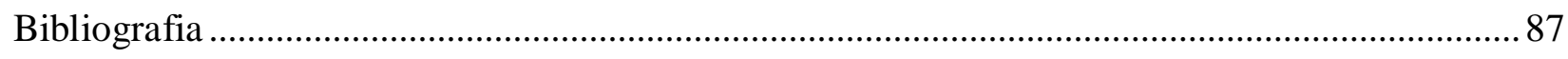

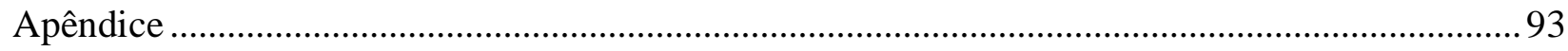

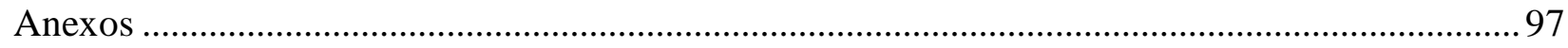

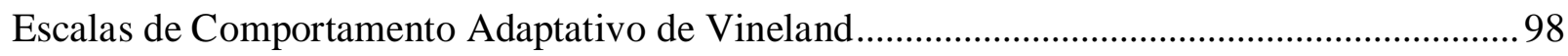

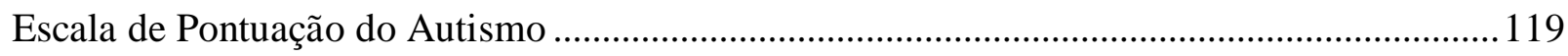

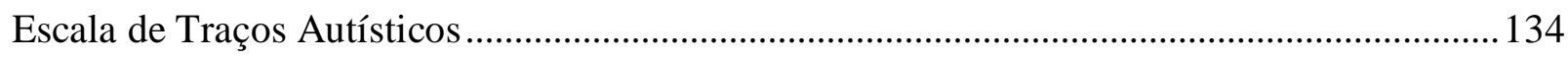

Escala de funcionamento global para crianças........................................................................141 


\section{Introdução}

\subsection{Considerações gerais}

As mucopolissacaridoses (MPS) são um grupo de doenças metabólicas hereditárias causadas pela deficiência de enzimas lisossomais específicas. A deficiência enzimática resulta em alterações na função celular devido ao acúmulo excessivo de glicosaminoglicanos (GAGS) parcialmente degradados no interior das células, especialmente nas áreas subendoteliais de diversos órgãos e tecidos (Barone, Nigro, Triulzi, Musumeci, Fiumara, \& Pavone, 1999). Os GAGS também são eliminados na urina dos pacientes afetados. A ampla distribuição dos GAGS no tecido conjuntivo corporal leva a uma ampla gama de manifestações clínicas (Wraith, 1995). O sistema nervoso central pode ser afetado em graus variados em todos os tipos de MPS, exceto nos tipos IS, IV e VI ${ }^{1}$. O padrão de herança para todas as MPS é autossômico recessivo, excetuando-se a MPS II, cujo padrão de herança é recessivo ligado ao X.

A classificação das MPS, os materiais acumulados e as respectivas deficiências enzimáticas encontram-se na tabela 1 :

\footnotetext{
${ }^{1}$ Estes tipos correspondem às Síndromes de Scheie, de Morquio e de Maroteaux-Lamy. Todos os tipos de MPS serão abordados com maiores detalhes na tabela 1 e nas páginas 2-7.
} 
Tabela 1: Classificação das Mucopolissacaridoses (Wraith, 1995) (de Paula, Kim, \& Albano, 2010)

\begin{tabular}{llll}
\hline Tipo & Epônimo & $\begin{array}{l}\text { Material } \\
\text { acumulado* }\end{array}$ & Deficiência Enzimática \\
\hline MPS IH & S. Hurler & DS, HS & Iduronidase \\
MPS IS & S. Scheie & DS, HS & Iduronidase \\
MPS IH/S & S. Hurler-Scheie & DS, HS & Iduronidase \\
MPS II & S. Hunter & DS, HS & Iduronato-sulfato-sulfatase \\
MPS IIIA & S. Sanfilippo & HS & Heparan-N-sulfatase \\
MPS IIIB & & HS & N-Acetilglicosaminidase \\
MPS IIIC & & HS & Acetil-CoA-glicosaminidase acetiltransferase \\
MPS IIID & & HS & N-Acetilglicosamina-6-sulfatase \\
MPS IVA & S. Morquio & QS & Galactosamina-6-sulfatase \\
MPS IVB & & QS & $\beta$-Galactosidase \\
MPS VI & S.Maroteaux-Lamy & DS & N-Acetilgalctosamina-4-sulfatase \\
MPS VII & S. Sly & CS, DS, HS & $\beta$-Glucuronidase \\
MPS IX & S. Natowicz & CS & Hialuronidase \\
\hline
\end{tabular}

* DS: dermatan sulfato; HS: heparan sulfato; QS: queratan sulfato; CS: condroitin sulfato.

Os quadros de MPS usualmente se apresentam em uma de três formas: (1) como uma síndrome dismórfica; (2) com distúrbios comportamentais e intelectuais graves; ou (3) com displasia óssea grave, dismorfismo moderado e inteligência normal. Deve-se ressaltar, também, que há um espectro de fenótipos que vão do mais leve ao mais gravemente afetado em todos os quadros conhecidos (Wraith, 1995).

A seguir, delineiam-se as características principais de cada um dos quadros. 


\section{MPS I (Síndrome de Hurler; Síndrome de Scheie; Síndrome de Hurler-Scheie)}

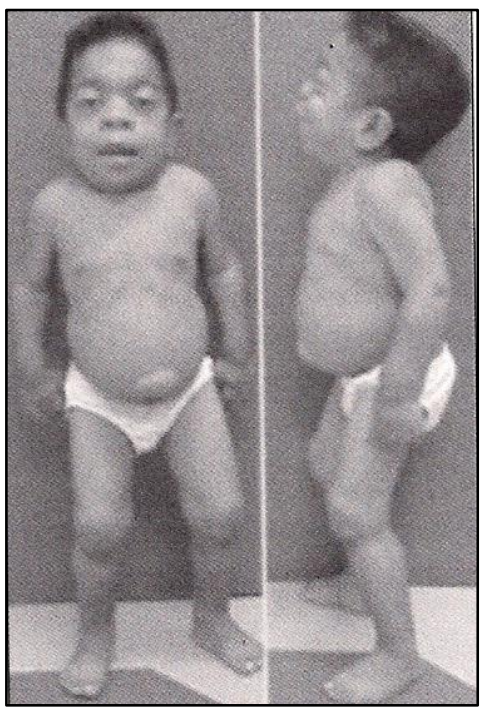

Figura 1: menino de oito anos com MPSI; observar fácies grosseira, pescoço curto, abdome volumoso, hérnia umbilical, rigidez articular e mãos em garra (de Paula, Kim, \& Albano, 2010).

A Síndrome (S) de Hurler foi descrita em 1919 e caracteriza-se por traços fisionômicos grosseiros, retardo mental, turvação da córnea aparecendo durante o segundo ano de vida e rigidez articular. No decorrer dos primeiros seis meses começam a aparecer alterações discretas da fisionomia, além de macrocefalia, hérnias (umbilical e inguinais), diminuição da mobilidade coxofemoral, respiração ruidosa e infecções freqüentes de vias respiratórias. A desaceleração do desenvolvimento físico e mental torna-se evidente a partir do segundo semestre de vida, sendo que a estatura final não costuma exceder os $110 \mathrm{~cm}$. O desenvolvimento cognitivo começa a tornar-se mais lento após o primeiro ano e o processo de perdas de habilidades se acelera a partir de então, sendo que aos três anos a maioria das crianças encontra-se na faixa de funcionamento do retardo mental, sendo que o nível do mesmo não é especificado nas referências consultadas. A mobilidade pode ser limitada devido à rigidez articular progressiva e ao abdome protuberante resultante de hepatoesplenomegalia. A morte é geralmente precoce, devido às complicações cardiorrespiratórias, notadamente cardiomiopatia. Também já foi descrita a ocorrência de hipertrofia assimétrica do septo interventricular, espessamento das valvas aórtica e mitral, insuficiência coronariana e morte súbita secundária a arritmias. Raramente esses pacientes ultrapassam a primeira década de vida (Wraith, 1995) (Jones, 1997) (Bjoraker, Delaney, Peters, Krivit, \& Shapiro, 2006). 
Apesar dos problemas físicos graves, o desenvolvimento intelectual inicial é geralmente normal e os pacientes passam a apresentar dificuldades de aprendizado mais tarde no curso da doença. A maior parte das crianças chega a desenvolver algumas habilidades sociais e muitas são capazes de frequentar creches e escolas de educação infantil comuns durante seus primeiros anos de vida (Wraith, 1995).

A Síndrome de Scheie foi descrita inicialmente em 1962, sendo classificada como MPS V. Posteriormente foi reclassificada como MPS IS. Caracteriza-se por ser uma forma "atenuada" da Síndrome de Hurler, com dismorfismo discreto e inteligência normal (Jones, 1997). As complicações observadas geralmente são as ortopédicas, com mau funcionamento das mãos, síndrome do túnel do carpo, rigidez articular e dores graves nas costas, com altas incidências de espondilolistese lombar e compressão da medula espinhal. Além disso, são comuns a insuficiência aórtica e/ou mitral e as alterações visuais decorrentes da opacificação corneana (Wraith, 1995).

O fenótipo intermediário entre as síndromes descritas anteriormente é conhecido como Síndrome de Hurler-Scheie e envolve todo um espectro de manifestações entre os dois extremos citados.

\section{MPS II (S. Hunter)}

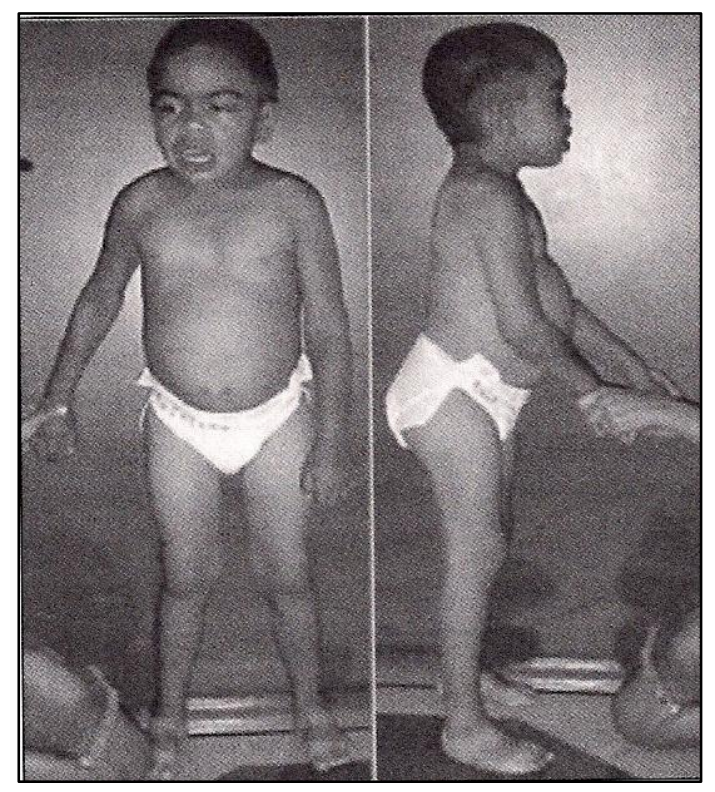

Figura 2: menino de nove anos com MPSII; observar fácies grosseiro, abdome globoso e rigidez articular (de Paula, Kim, \& Albano, 2010). 
A Síndrome de Hunter foi a primeira mucopolissacaridose a ser descrita, em 1917. Caracteriza-se por fácies grosseira, atraso do crescimento (estatura final entre 120 e $150 \mathrm{~cm}$ ), rigidez articular e córneas transparentes. Assim como na MPS I, problemas de vias aéreas, nariz, ouvidos e garganta são comuns. Além disso, observa-se disfunção gastrointestinal freqüente, com a manifestação mais comum sendo episódios graves de diarréia cuja causa ainda permanece desconhecida (Jones, 1997) (Wraith, 1995). Nos casos mais graves, a neurodegeneração progressiva resulta em um estado vegetativo a partir do início da adolescência, com morte ao redor da idade de 15-16 anos. Em um estudo realizado por Young e colaboradores com 83 pacientes (Young, Harper, Newcombe, \& Archer, 1982), as características que desencadearam a preocupação dos cuidadores e levaram ao diagnóstico da condição dependeram da gravidade do quadro. Assim, nos casos mais leves o sintoma de apresentação foi a aparência facial e nos mais graves, o atraso de desenvolvimento.

\section{MPS III (S. Sanfilippo)}

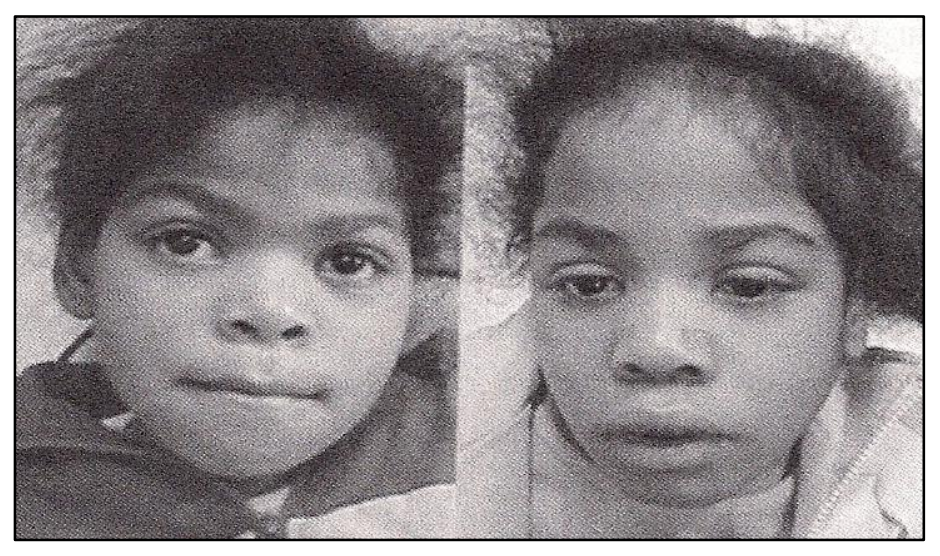

Figura 3: irmãs gêmeas de 9 anos com MPS III; face normal (de Paula, Kim, \& Albano, 2010).

A Síndrome de Sanfilippo foi descrita em 1963, caracterizando-se por fácies ligeiramente grosseira, rigidez articular discreta e retardo mental (Jones, 1997), devido a uma doença neurodegenerativa grave (Cleary \& Wraith, 1993). O distúrbio de comportamento frequentemente é a característica mais marcante desses indivíduos e, muitas vezes, é incapacitante e de difícil controle (Wraith, 1995) (Bax \& Colville, 1995) (Robertson, Klug, \& 
Rogers, 1998). Alguns autores sugerem que tais alterações podem ser devidas a aumentos intermitentes da pressão intracraniana (Robertson, Klug, \& Rogers, 1998).

Foi sugerido que podem ser observados três estágios da doença, sendo que o primeiro caracteriza-se por atraso do desenvolvimento, principalmente da fala, entre o primeiro e o terceiro anos de vida. Ao redor dos 3 a 4 anos, surge o segundo estágio, durante o qual os pacientes apresentam problemas comportamentais graves com hiperatividade e manifestações destrutivas. Nesta fase, as funções e a autonomia previamente adquiridas são perdidas. Dificuldades motoras crescentes devido à espasticidade e à rigidez articular marcam o terceiro estágio da doença, começando a partir dos cerca de 10 anos de idade (Cleary \& Wraith, 1993) (Barone, Nigro, Triulzi, Musumeci, Fiumara, \& Pavone, 1999).

\section{MPS IV (S. Morquio)}

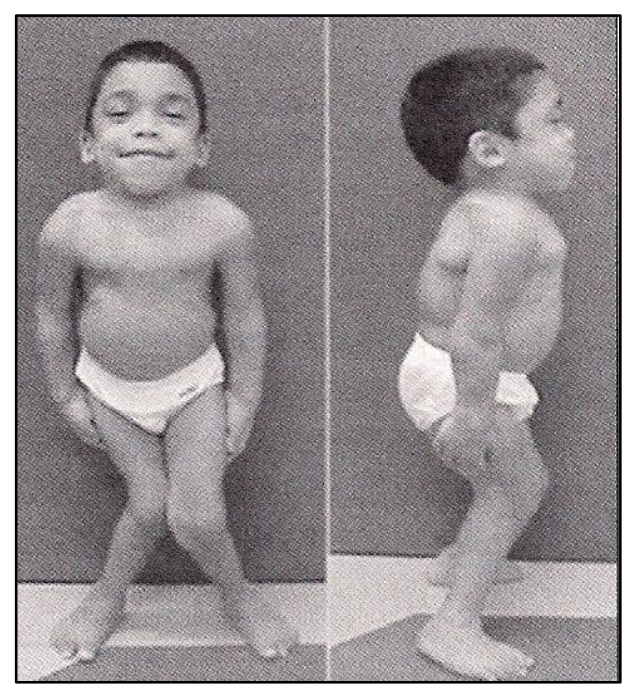

Figura 4: menino de nove anos com MPSIV; observar pescoço curto, pectus carinatum, rigidez articular e genu valgum (de Paula, Kim, \& Albano, 2010).

Foi descrita em 1929, apresentando fisionomia discretamente grosseira, cifose e genu valgo acentuados e opacificação corneana (Jones, 1997). O quadro clínico é dominado por displasia óssea grave e deformidades de coluna, com poucos pacientes atingindo alturas que ultrapassem os $100 \mathrm{~cm}$. Os pacientes com MPS IV também são atingidos por doenças de ouvidos, nariz e garganta, além de terem dentes característicos e propensos à formação de cáries. Os marcos de desenvolvimento neuropsicomotor são atingidos normalmente, embora o equilíbrio 
seja afetado pelas anomalias ósseas. A expectativa de vida é boa, desde que sejam evitadas as complicações cervicais secundárias à deformidade de coluna e à instabilidade da articulação crânio-cervical (Wraith, 1995).

Crianças com síndrome de Morquio foram descritas, em um estudo, como particularmente confusas (Bax \& Colville, 1995) ${ }^{2}$.

MPS VI (S. Maroteaux-Lamy)

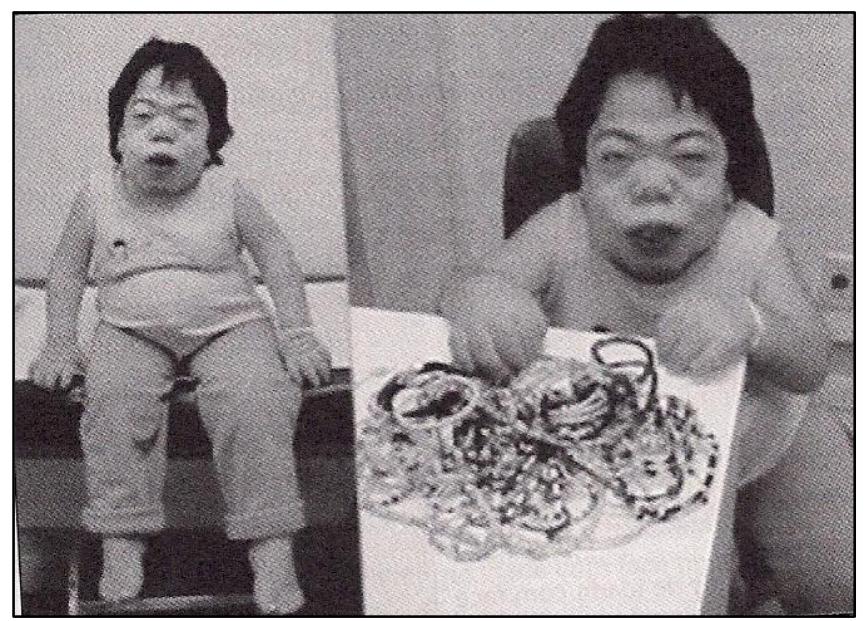

Figura 5: paciente de vinte anos com MPSVI; observar baixa estatura, fáscies grosseira, pescoço curto, abdome volumoso e mãos em garra (de Paula, Kim, \& Albano, 2010).

Caracteriza-se por fácies grotesca, rigidez articular e opacificação corneana no lactente (Jones, 1997). A complicação mais séria é o estreitamento progressivo e difuso das vias aéreas, levando a cor pulmonale e morte no final da adolescência ou início da idade adulta. O sistema nervoso central desses pacientes não é afetado e não são descritas alterações de QI (Wraith, 1995). Contudo, em um relato sobre uma família vietnamita com três casos de MPS VI, uma das crianças avaliadas foi descrita como possuindo um atraso de desenvolvimento, embora não se tenha caracterizado em que consistia tal atraso (Handelman, Menahem, \& Eisenbruch, 1989).

\footnotetext{
${ }^{2}$ No estudo original, não há maiores esclarecimentos sobre a que se refere tal comportamento confuso.
} 
MPS VII (S. Sly)

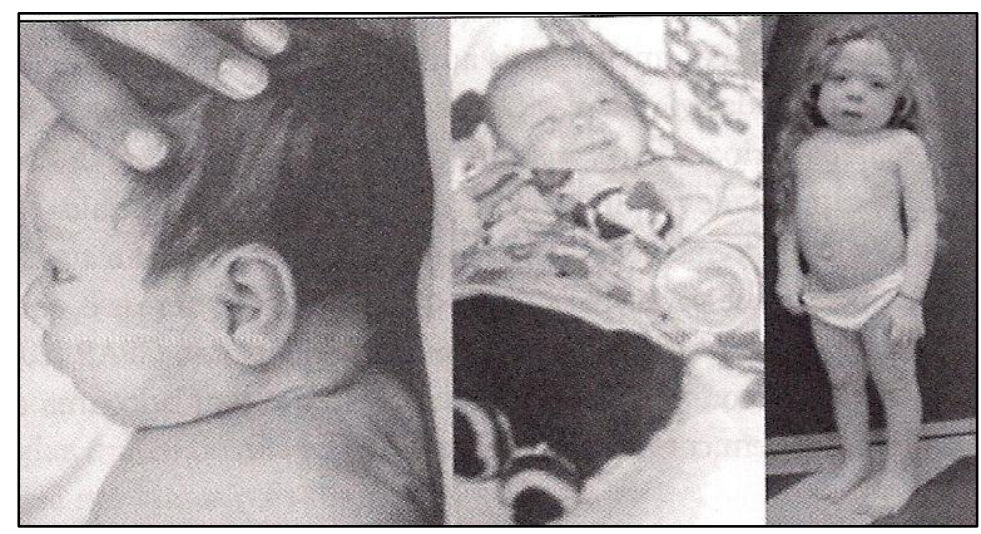

Figura 6: menina com MPSVII em diversos momentos de sua vida; observar excesso de pele na região do pescoço, baixa estatura e pescoço curto (de Paula, Kim, \& Albano, 2010).

Caracteriza-se por anormalidades esqueléticas moderadas, hérnias umbilical e/ou inguinal, hepatoesplenomegalia, fácies grotesca, baixa estatura, infecções respiratórias recorrentes e atraso de desenvolvimento (Udwin \& Dennis, 1995).

\section{MPS IX (S. Natowicz)}

Até o momento, há apenas um caso descrito na literatura, caracterizado por baixa estatura e múltiplos nódulos articulares. Não há relato de alterações de comportamento nessa paciente (Coutinho, Lacerda, \& Alves, 2012).

\subsection{Fenótipos comportamentais}

A expressão fenótipo comportamental foi cunhada em 1971, por William L. Nyhan, então presidente da Society for Pediatric Research, referindo-se a crianças com doenças 
genéticas. Um fenótipo comportamental é um padrão característico de observações motoras, cognitivas, linguísticas e sociais consistentemente associado a uma condição biológica. Em alguns casos, o fenótipo comportamental pode ser um transtorno mental. Em outros, comportamentos que não são usualmente vistos como parte de transtornos mentais podem ser as características mais proeminentes, sem configurarem transtornos propriamente ditos $\left(\mathrm{O}^{\prime} \mathrm{Brien} \&\right.$ Yule, 1995).

Assim, um fenótipo comportamental não se restringe à ocorrência de determinados transtornos de forma consistentemente associada a uma síndrome específica, embora tais transtornos possam fazer parte de um fenótipo comportamental.

A interação desses elementos na determinação de um fenótipo comportamental é importante, sendo que em um fenótipo específico, um ou alguns desses componentes podem ser mais proeminentes que os outros. A figura seguinte ilustra essa interrelação

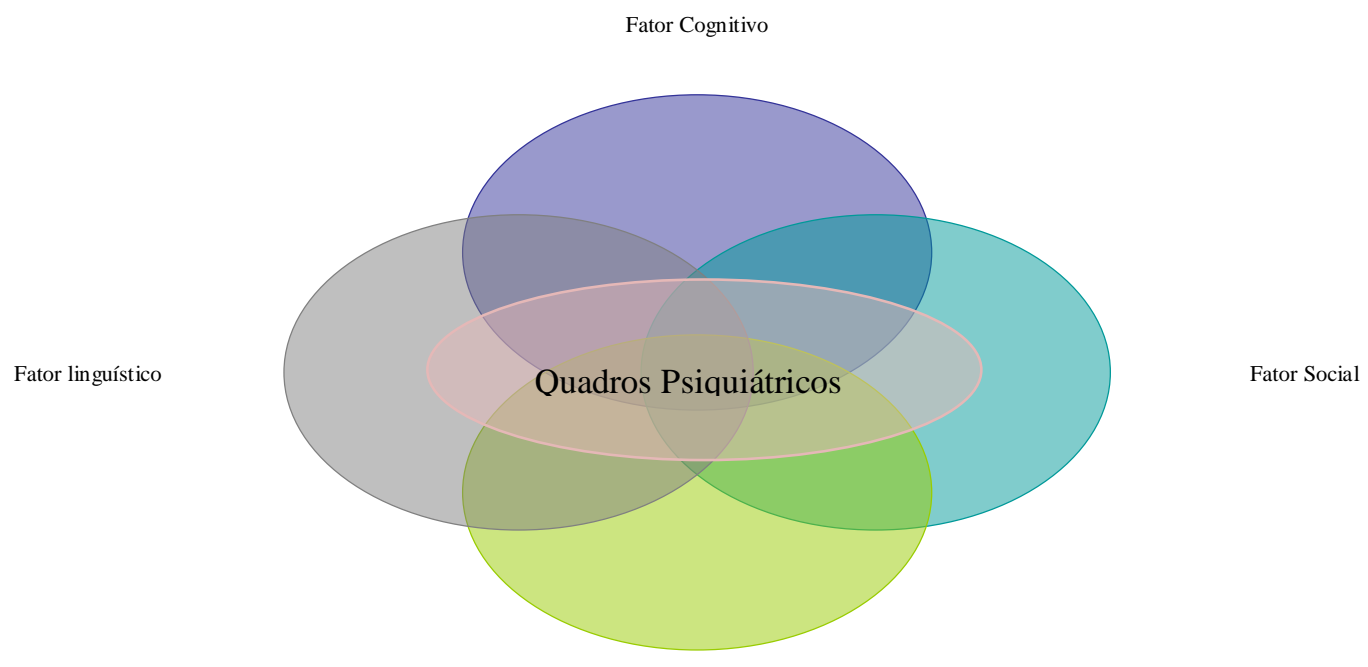

Fator Motor

Figura 7: Interação entre os fatores que compõem um fenótipo comportamental. Note-se que os quadros psiquiátricos constituem apenas uma pequena parte das características possíveis (modificado de O'Brien \& Yule, 1995). 
A importância do reconhecimento de que um comportamento pode ter uma origem mista, ou seja, de que pode sofrer influências comportamentais e genéticas em sua determinação é o fato de que sua observação pode ser de tremendo auxílio no estabelecimento de diagnósticos de crianças com transtornos de desenvolvimento e, também, na determinação de medidas de cuidados e manejo, bem como do prognóstico do quadro, questão sempre presente para profissionais e familiares.

\subsection{Manifestações comportamentais em pacientes com mucopolissacaridoses}

No que se refere ao perfil cognitivo, dificuldades de aprendizagem com deterioração mental progressiva são características comuns às síndromes de Hurler, Hunter e Sanfilippo. Capacidade atencional limitada e distraibilidade são proeminentes e o desenvolvimento da fala é particularmente atrasado quando comparado a outras características. Algumas crianças nunca chegam a desenvolvê-la. Outras têm seu desenvolvimento atrasado e perdem as habilidades conforme a doença progride. Em contraste com essas manifestações mais graves, pacientes com síndrome de Scheie, alguns casos mais leves de síndrome de Hunter e pacientes com síndromes de Morquio e Maroteaux-Lamy apresentam-se geralmente com inteligência normal ou dificuldades de aprendizado moderadas (Udwin \& Dennis, 1995).

Crianças com MPS também apresentam altas taxas de problemas de comportamento, extremamente variados em suas características. Ao menos em parte, eles podem ser concomitantes com os baixos níveis cognitivos e com os aspectos degenerativos das doenças. Por outro lado, eles também ocorrem em indivíduos afetados com desenvolvimento normal, sugerindo outros possíveis fatores causais e/ou desencadeantes envolvidos. Crianças com síndromes de Hunter, Hurler e Sanfilippo apresentam elevados índices de problemas de sono (Bax \& Colville, 1995) (Udwin \& Dennis, 1995). Esses problemas serão detalhados mais adiante no texto.

Bax \& Colville (1995) analisaram questionários enviados a famílias de 258 sujeitos de 0 a 14 anos afetados por mucopolissacaridoses de tipos I a IV, além de procederem a observação direta de 42 dessas crianças. Os comportamentos avaliados foram as capacidades de 
andar, falar frases, usar o banheiro e a presença de sintomas como alterações de sono, inquietação, destrutividade, medo excessivo e "confusão"3. A presença de cada uma dessas características nas crianças avaliadas está ilustrada na tabela seguinte.

Tabela 2: Características comportamentais de 258 indivíduos com mucopolissacaridoses

\begin{tabular}{lllll}
\hline & MPS I & MPS II & MPS III & MPS IV \\
\hline Anda & $57 \%$ & $92 \%$ & $79 \%$ & $84 \%$ \\
Fala frases & $33 \%$ & $44 \%$ & $25 \%$ & $96 \%$ \\
Usa o banheiro & $16 \%$ & $13 \%$ & $6 \%$ & $44 \%$ \\
Alterações de sono & $59 \%$ & $63 \%$ & $86 \%$ & $44 \%$ \\
Destrutividade & $8 \%$ & $42 \%$ & $57 \%$ & $4 \%$ \\
Inquietação & $41 \%$ & $69 \%$ & $69 \%$ & $8 \%$ \\
Medo excessivo & $65 \%$ & $73 \%$ & $55 \%$ & $36 \%$ \\
“Confusão" & $10 \%$ & $17 \%$ & $7 \%$ & $40 \%$ \\
\hline
\end{tabular}

1

Cabe ressaltar que as alterações de sono observadas nas crianças com MPS I estavam geralmente associadas a complicações médicas (especialmente respiratórias) inerentes à síndrome, ao contrário das dificuldades relatadas/observadas nos pacientes com MPS III. Além disso, estes últimos foram frequentemente descritos como imprevisíveis, agressivos e destrutivos sem razão aparente para seu comportamento, bem como bastante inquietos até que a progressão da doença minasse sua mobilidade. Observou-se, também, a ocorrência freqüente do hábito de colocar na boca ou morder roupas e outros objetos. Os distúrbios de sono observados nos portadores de MPS III foram ficar acordado a noite toda (45\%), andar pela casa (38\%) e rir e cantar durante a madrugada (15\%). Os autores concluem que pacientes com mucopolissacaridoses apresentam altas taxes de problemas de comportamento e que, embora esse comportamento desorganizado geralmente seja atribuído ao depósito anormal de metabólitos no sistema nervoso central, uma explicação alternativa é a de que ao menos alguns deles reflitam

\footnotetext{
${ }^{3}$ Não há esclarecimento sobre a que se refere tal comportamento no texto original.
} 
efeitos mais diretos da expressão genética. Um dado importante para a prática clínica diária é o de que uma proporção significativa de famílias mencionou que os comportamentos difíceis foram as primeiras alterações notadas, embora às vezes isso tenha ocorrido muitos anos antes de a condição da criança ser diagnosticada (Bax \& Colville, 1995).

No Brasil, estudo (Albano, et al., 2000) que avaliou 19 pacientes com quadros de MPS, observou atraso de desenvolvimento em 8 deles (MPS I, II, III e IV).

Crianças com síndrome de Hurler são frequentemente descritas como medrosas e ansiosas, especialmente nos anos pré-escolares, mas são raramente agressivas ou destrutivas (Bax \& Colville, 1995) (Udwin \& Dennis, 1995). Outro estudo as descreve como apáticas, amigáveis e plácidas (Omenn, 1976).

O relato dos casos de 16 pacientes com MPS I no Marrocos, com idades de 3 a 20 anos, mostrou que todos, exceto um menino de 3 anos, apresentavam rendimento compatível com retardo mental, com QI total variando de 50 a 56. Apesar dos dados sobre o coeficiente intelectual estarem presentes, não foram relatadas as características específicas dos déficits cognitivos e nem a presença (ou ausência) de sintomas comportamentais associados (Alif, et al., 2000).

Um estudo (Bjoraker, Delaney, Peters, Krivit, \& Shapiro, 2006) sobre 41 crianças com MPSIH que avaliou suas funções adaptativas a partir das Escalas de Comportamento Adaptativo de Vineland obteve os seguintes standard scores e desvios-padrão para os diferentes

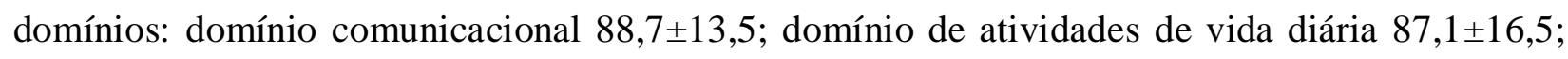

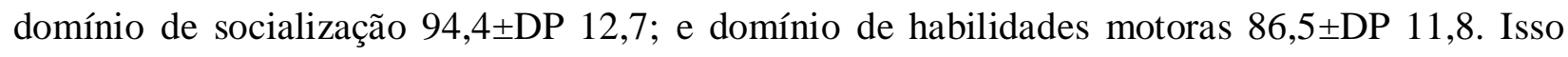
significa que todas as crianças tinham deficiências em seu funcionamento adaptativo, independentemente das manifestações específicas da doença em cada uma e que todas elas demonstravam um padrão de comunicação, socialização e autocuidado inferiores ao esperado para sua idade.

Há relato de caso de um menino de 15 anos com MPS tipo I (Dugas, Le Heuzey, \& Mayer, 1985), na França, que apresentou sintomatologia psicótica caracterizada por delírios persecutórios pouco estruturados, alucinações visuais e auditivas e interpretações delirantes, além de sintomas relativos ao humor, que se mostrou alternadamente deprimido e exaltado conforme a evolução ao longo do tempo. 
Os meninos com S. Hunter podem ser hiperativos e inquietos, com pouca capacidade de concentração. Também podem ser teimosos e difíceis de disciplinar, além de mostrarem rompantes de comportamento agressivo e destrutivo. Conforme a doença progride, a hiperatividade diminui e as crianças tornam-se cada vez mais apáticas (Bax \& Colville, 1995) (Udwin \& Dennis, 1995) (Young, Harper, Newcombe, \& Archer, 1982) (Young \& Harper, Psychosocial problems in Hunter's syndrome, 1981) (Omenn, 1976). Cabe ressaltar que, segundo o estudo de Young e colaboradores de 1982, as manifestações comportamentais também variam com a gravidade do quadro, sendo que os pacientes com quadros mais leves não apresentaram alterações comportamentais, mas tinham problemas psicológicos durante e após a adolescência. Por outro lado, os meninos com casos mais graves apresentaram alterações comportamentais importantes, como hiperatividade (76\%), teimosia (47\%), agressividade (42\%) e comportamento exuberante (26\%). Esse mesmo estudo mostrou que o envolvimento neurológico progressivo dominou o curso dos casos mais graves, sendo que o desenvolvimento neuropsicomotor se interrompia ao redor dos 6 anos de idade e, a partir de então, começava a regredir de forma que com cerca de 10 anos, a maioria dos pacientes encontrava-se acamada e totalmente dependente. O grau de comprometimento neurológico e comportamental foi usado para definir duas apresentações possíveis da síndrome de Hunter, uma leve e outra grave.

Os problemas comportamentais também são frequentes na S. Sanfilippo, começando geralmente ao redor de 3 ou 4 anos de idade e associados com a regressão do desenvolvimento. As crianças mostram crises de birra cada vez mais graves e frequentes, obstinação, períodos de agressividade e destrutividade, hiperatividade e inquietação progressivas e diminuição rápida da capacidade atencional. Podem apresentar autoagressividade, gritos incessantes, movimentos estereotipados e pica (Robertson, Klug, \& Rogers, 1998). Com o passar do tempo, tornam-se mais quietos, sendo que as crianças ficam mais retraídas, perdendo contato com o ambiente devido à deterioração, além de apresentarem alterações de humor e crises de choro freqüentes (Dhondt, Farriaux, Fournier, \& Fontaine, 1974) (Bax \& Colville, 1995) (Udwin \& Dennis, 1995) (Barone, Fiumara, Villani, Di Natale, \& Pavone, 2001) (Ucar, Ozbaran, Demiral, Yuncu, Erermis, \& Coker, 2009). Há relatos de casos de autismo associados à síndrome de Sanfilippo (Zafeiriou, Ververi, \& Vargiami, 2007).

Um estudo norteamericano realizado através do preenchimento de questionários por 30 familiares de pacientes com MPS III (16 meninas e 14 meninos) (Nidiffer \& Kelly, 1983) 
avaliou os padrões comportamentais e degenerativos desses indivíduos no que se refere a informações gerais, história da doença, problemas comportamentais e questões familiares. Assim, observou-se que o desenvolvimento cognitivo e social/adaptativo das crianças com MPS III é, grosso modo, paralelo ao das crianças normais até os 3-4 anos de idade, porém com maior variabilidade no que se refere à idade de aquisição de qualquer marco do desenvolvimento escolhido. Além disso, a deterioração das capacidades não se relaciona direta ou inversamente à ordem de sua aquisição. A primeira área a ser identificada como declinante pelos pais era geralmente a da linguagem e da memória, entre os 3,5 e 6,5 anos. Os problemas comportamentais mais frequentemente mencionados foram aqueles relacionados ao declínio das funções (linguagem, alimentação, necessidade de supervisão constante, memória e enurese), embora outros também tenham sido mencionados (crises de birra, comportamento disruptivo). No que se refere às influências ambientais e fisiológicas, a hiperatividade, agressividade, dificuldades com os pares e ansiedade tenderam a ser mais sensíveis a variações ambientais que muitos dos outros problemas apontados. Em outras palavras, embora tais comportamentos pareçam ter uma predisposição genética, diferenças em suas manifestações foram vistas nos mesmos pacientes com diferentes pessoas, lugares ou horas do dia. Uma conclusão importante é a de que a freqüência de alguns dos problemas de comportamento excede o esperado mesmo para crianças com deficiência mental, podendo ser considerados como parte da própria síndrome, como a hiperatividade, a agressividade, a teimosia e a autoestimulação, todos eles presentes em mais de $70 \%$ dos casos.

Kim et al. (1996) relataram caso de uma jovem americana de 17 anos com S. Sanfilippo encaminhada ao psiquiatra por um quadro de vários meses de impulsividade e agressividade crescentes, chegando até à ideação homicida em relação a sua mãe. A família relatou início súbito de desobediência em casa e na escola e uma tendência a sair sem rumo sem avisar a ninguém, além de começar a brigar na escola e a roubar cigarros. Durante a avaliação, observou-se humor disfórico, agitação, afeto lábil e inapropriado, pensamento concreto, idéias perseverantes e juízo e crítica diminuídos. A avaliação através do WAIS-R (Wechsler Individual Achievement Test-Revised) revelou QI verbal=78, QI execução=70 e QI total=79, demonstrando funcionamento intelectual compatível com a faixa de inteligência limítrofe. Este resultado foi compatível com a observação clínica de atrasos de desenvolvimento em todas as áreas de funcionamento. O diagnóstico psiquiátrico dado pela equipe assistente foi de Transtorno do 
Humor devido a Condição Médica Geral, obtendo-se boa resposta terapêutica com a associação de carbamazepina 300mg/dia e intervenções psicossociais (Kim, Berger, Bunner, \& Carey, 1996).

Um estudo de seguimento realizado com três pacientes com MPS III na Itália assinalou as datas de início dos principais achados neurológicos e comportamentais, sendo que: a idade de diagnóstico variou de 20 meses a 12 anos; o surgimento dos problemas de fala deu-se entre os 20 meses e os 3 anos e meio; o déficit de atenção foi observado entre os 30 meses e os 4 anos; e a inquietação, entre os 3 e os 4 anos e meio. Todos os pacientes tinham diagnóstico de retardo mental, com QI total entre <30 e 44 (ou seja, entre os níveis de deficiência mental grave e moderada), não possuindo controle esfincteriano e necessitando de supervisão constante. Dois dos pacientes demonstraram, ainda, alterações bruscas de humor, destrutividade e problemas de sono. O mais velho, aos 12 anos, ainda apresentava perda da comunicação desde os 5 anos, crises epiléticas desde os 8 anos e meio, estereotipias e regressão motora (Barone, Nigro, Triulzi, Musumeci, Fiumara, \& Pavone, 1999).

Outro estudo, desta vez do Reino Unido, avaliou 62 crianças portadoras de MPS III e, além de observarem a evolução dos sintomas neuropsiquiátricos em três fases, conforme já citado, as detalharam de forma mais prolongada. Assim, na primeira fase da doença, observou-se que os problemas de desenvolvimento concerniam principalmente à aquisição da linguagem e que os marcos motores principais são conquistados, embora o possam ser de forma retardada. Cinquenta por cento dessas crianças não conseguiram completar o treino de toalete. Os distúrbios de comportamento encontrados na segunda fase foram crises de birra cada vez mais intensas e freqüentes, muitas vezes seguidas por hiperatividade e uma rápida diminuição do span atencional. Agressividade e destrutividade foram comuns. Ainda ocorreram ataques de pânico quando expostos a locais ou situações desconhecidos, distúrbios graves de sono e, às vezes, episódios alucinatórios durante a noite. Na terceira e última fase, os problemas comportamentais tenderam a diminuir, devido às restrições físicas da doença. Crises epiléticas tonicoclônicas generalizadas tornaram-se um problema nesse período (Cleary \& Wraith, 1993).

$\mathrm{Na}$ França, Jabourian et al. citam criança cuja sintomatologia clínica lhe rendeu uma hipótese diagnóstica de autismo, em conjunto com o quadro de MPS III (Jabourian, Benhamou, \& Bitton, 1996). 
O Registro Internacional de MPS IV (Montaño, Tomatsu, Gotterman, Smith, \& Orii, 2007) colheu dados sobre o curso clínico de 326 indivíduos de diversos países portadores da síndrome através de um questionário auto-administrável que incluía questões sobre história ao nascimento, história familiar, idades de início dos sintomas e do diagnóstico, sinais e sintomas, curso clínico, intervenções cirúrgicas, peso e altura atuais, atividade física e outras queixas. Nesse estudo, não há menção a qualquer tipo de manifestação comportamental, seja como sintoma direto da doença, seja como consequiência de seu acometimento físico.

De maneira similar, o Registro Internacional de MPS I cita brevemente a ocorrência de prejuízos cognitivos em uma parcela dos 302 pacientes avaliados, porém sem detalhar as características de tal comprometimento (Pastores, et al., 2007).

Assim, observa-se que, apesar de o estudo deste grupo de doenças remontar às primeiras décadas do século XX, ainda se conhece muito pouco sobre suas características comportamentais e sobre a ocorrência de transtornos psiquiátricos nessa população. 


\section{Justificativa}

A partir da literatura existente, e considerando que as síndromes genéticas já conhecidas podem apresentar um perfil comportamental característico, faz-se necessária a realização de estudos cujo objetivo seja definir tais padrões, uma vez que a confirmação de sua existência forneceria elementos extras para a realização de diagnósticos mais precoces e um tratamento potencialmente mais adequado para cada paciente.

No caso específico das mucopolissacaridoses, embora haja diversos relatos na literatura sobre as altas taxas de ocorrência de problemas de comportamento na síndrome de Sanfilippo (MPS III) (Kim, Berger, Bunner, \& Carey, 1996) (Barone, Fiumara, Villani, Di Natale, \& Pavone, 2001) (Ucar, Ozbaran, Demiral, Yuncu, Erermis, \& Coker, 2009), muito pouco é conhecido sobre as características comportamentais das outras entidades (MPS I, II, IV, VI e VII).

Vale ressaltar que, entre os estudos internacionais, predominam os levantamentos da ocorrência de sintomas isolados, em detrimento de transtornos mentais específicos. Além disso, nenhum estudo nacional cujo enfoque fossem as manifestações comportamentais dessas síndromes foi encontrado.

Dessa forma, este trabalho pretendeu contribuir para a investigação da existência de características comportamentais específicas associadas às mucopolissacaridoses, bem como estimar a ocorrência de transtornos mentais na população acometida por este grupo de doenças. 


\section{Objetivos}

Avaliar e descrever as alterações psiquiátricas encontradas em pacientes com MPS, bem como seu nível de comportamento adaptativo e de funcionamento global, realizando um diagnóstico multiaxial para cada caso estudado. 


\section{Casuística}

Foram avaliados vinte e dois pacientes com diagnóstico confirmado de MPS em atendimento ambulatorial em três serviços de genética clínica, cuja idade fosse de 2 até dezoito anos completos. O diagnóstico foi feito a partir de exame clínico e laboratorial, através da dosagem da enzima deficiente no sangue periférico.

Os pais ou responsáveis legais do paciente assinaram um termo de consentimento livre e esclarecido aprovado pelo comitê de ética em pesquisa do serviço em questão (vide anexo). 


\section{Método}

\subsection{Delineamento geral}

O trabalho proposto foi realizado sob a forma de um estudo observacional das características da população de crianças e adolescentes com diagnóstico clínico e laboratorial confirmado de mucopolissacaridoses em três serviços de genética clínica do estado de São Paulo.

A coleta dos dados foi feita no período de setembro de 2011 a outubro de 2012, recrutando-se como participantes os pacientes já matriculados no Ambulatório de Mucopolissacaridoses do Serviço de Genética do Instituto da Criança do Hospital das Clínicas da Faculdade de Medicina da Universidade de São Paulo, do Serviço de Genética do Hospital Municipal de Guarulhos e do Serviço de Genética do Hospital das Clínicas da Faculdade de Medicina de Ribeirão Preto. O $n$ desejado foi de 33 pacientes, sendo este o número de pacientes conhecidos em acompanhamento nos serviços citados. Não foi possível, contudo, alcançar este número de sujeitos e o estudo foi realizado com 22 pacientes.

Houve apenas uma entrevistadora, que se apresentou aos pacientes e familiares logo após a consulta com o médico geneticista (no caso dos pacientes em acompanhamento ambulatorial) ou durante as sessões de reposição enzimática (no caso dos pacientes que recebem esse tipo de tratamento). $\mathrm{O}$ delineamento do estudo foi apresentado e foram esclarecidas todas as dúvidas pertinentes ao mesmo, apresentando-se em seguida o termo de consentimento informado e esclarecido, já aprovado por comitê de ética, para assinatura pelos responsáveis legais dos pacientes que concordaram em participar da entrevista.

Após a avaliação, quando constatada a presença de qualquer transtorno mental, foi feito o esclarecimento da família e o contato com o médico assistente do caso, para fornecer encaminhamento adequado para cada situação específica.

Após a coleta, foi organizado um banco de dados com os resultados obtidos e feita uma análise dos dados, incluindo as histórias clínicas, as características sociodemográficas, as frequências dos transtornos encontrados, o perfil de comportamento adaptativo e as questões psicossociais envolvidas nos casos estudados. 
Não houve financiamento externo (patrocínio) para o presente projeto, sendo que os eventuais custos com materiais (fotocópias, testes, microcomputadores) foram supridos pela autora.

\subsection{Diagnóstico}

A avaliação psiquiátrica foi feita através de anamnese com os familiares e os pacientes, a observação direta dos mesmos, a realização de entrevista psiquiátrica semiestruturada e a aplicação de instrumentos de screening diagnóstico para os transtornos invasivos do desenvolvimento. Além disso, foi feita avaliação do desenvolvimento adaptativo dos pacientes através da aplicação de escala específica para tal, bem como de seu funcionamento global.

Os instrumentos utilizados foram:

- Schedule for Affective Disorders and Schizophrenia for School-Age Children / Present and Lifetime Version (K-SADS-PL): criada por Kaufman e cols em 1997, é uma entrevista psiquiátrica semiestruturada que tem como objetivo detectar transtornos psiquiátricos em crianças e adolescentes de 6 a 12 anos. Sua versão brasileira foi validada por Brasil em 2003 (Brasil, 2003).

- Children's Global Assessment Scale (CGAS): é uma escala para avaliação do funcionamento global de crianças de 4 a 16 anos de idade, desenvolvida por Shaffer e cols em 1983 e validada por Brasil em 2003 (Brasil, 2003).

- Child Autism Rating Scale (CARS): de autoria de Schopler e cols e publicada em 1980, a CARS é uma das escalas mais usadas para a detecção do autismo. Divide-se em 14 itens graduados segundo a gravidade dos comportamentos avaliados. Sua validação brasileira foi feita por Pereira e cols em 2008 (Pereira, Riesgo, \& Wagner, 2008). O ponto de corte utilizado foi um score de 30. 
- Escala de Avaliação de Traços Autísticos (ATA): elaborada por Ballabriga e cols em 1994, é composta por 23 subescalas divididas em diversos itens e pode ser aplicada em crianças a partir dos 2 anos de idade. Foi validada em nosso país por Assumpção Junior e cols em 1999 (Assumpção Jr, Kuczynski, Gabriel, \& Rocca, 1999). O ponto de corte utilizado foi um score de 15.

- Escalas de Comportamento Adaptativo de Vineland: desenvolvido a partir de uma revisão da Vineland Social Maturity Scale, criada por Doll em 1935 e aprimorada pelo mesmo autor em 1965. Este instrumento avalia a adaptação social e pessoal dos indivíduos desde a infância até a idade adulta e é aplicável a pessoas com e sem deficiências. Existem três versões disponíveis, sendo que neste estudo foi utilizada a versão para triagem (Survey Form), que consiste em 297 itens que medem o desempenho em quatro domínios: comunicação, habilidades de vida diária, socialização e habilidades motoras. Embora haja uma tradução do instrumento, o mesmo ainda não foi validado para a população brasileira (Sparrow, Balla, \& Cicchetti, 1984).

Dessa forma, iniciou-se a avaliação com uma entrevista aberta, compreendendo a apresentação da pesquisadora e do trabalho, identificação das características pessoais e familiares dos entrevistados e anamnese clínica. Realizou-se, também, o exame objetivo dos indivíduos.

Em seguida, foi feita a aplicação do K-SADS, conduzido como uma entrevista semi-estruturada, onde a pesquisadora segue um roteiro básico, porém tem liberdade de esclarecer ou investigar melhor pontos de interesse, bem como de abrir espaço para comentários dos entrevistados. Nesses casos, os mesmos foram, também, anotados, por apresentarem possível relevância clínica.

Um terceiro passo foi a aplicação das Escalas de Comportamento Adaptativo de Vineland, cuja condução se assemelha à anteriormente descrita para a K-SADS. Dessa forma, procurou-se valorizar, além dos dados objetivos fornecidos pelos instrumentos, a experiência da entrevista e as impressões clínicas decorrentes dela.

Os instrumentos remanescentes (ATA, CARS, CGAS) foram completados pela pesquisadora após a liberação dos pacientes, uma vez que se baseiam nas impressões e 
observações clínicas do avaliador e não necessitam da participação ativa dos indivíduos avaliados.

Após a fase com o paciente, foi realizada a pontuação de todos os instrumentos, além da organização dos dados clínicos, para a elaboração de um diagnóstico multiaxial para cada paciente. Uma vez que a K-SADS é baseada nos critérios diagnósticos propostos pelo DSMIV, seguimos o modelo de diagnóstico multiaxial dessa classificação diagnóstica. Assim, utilizamos:

- Eixo 1: Diagnóstico Psiquiátrico Atual, a partir dos dados obtidos com anamnese, exame objetivo e instrumentos (K-SADS, ATA, CARS).

- Eixo 2: Nível de Desenvolvimento, a partir dos dados obtidos com as Escalas de Comportamento Adaptativo de Vineland.

- Eixo 3: Doenças Clínicas Associadas.

- Eixo 4: Características Familiares/Sociais.

- Eixo 5: Nível de Funcionamento Global, a partir do score de CGAS.

Cabe ressaltar que, uma vez que as entrevistas foram realizadas com o objetivo de uma pesquisa, optou-se por respeitar os parâmetros propostos pelos instrumentos para a realização e apresentação dos diagnósticos. No entanto, alguns pacientes apresentavam sintomas de relevância clínica, mesmo sem preencherem todos os critérios diagnósticos propostos pelo DSM, sendo que as famílias foram orientadas de acordo com a avaliação clínica pessoal da pesquisadora.

A análise dos dados foi feita, em sua maioria, de forma descritiva. Para os dados que permitiram uma análise estatística, foi utilizado o pacote estatístico Bioestat 5.0 (Ayres, Ayres Jr, Ayres, \& Santos, 2001), sendo utilizados os testes binomial, G e correlação linear de Pearson, todos com nível de significância de 0,05 . Os teste $\mathrm{G}$ e binomial são utilizados para realizarem-se inferências estatísticas comparando-se os dados da amostra e os parâmetros da população investigada. A correlação linear de Pearson proporciona um meio de verificar a associação entre duas variáveis. 


\section{Resultados}

Foram avaliados 22 pacientes de um total inicial de 33 conhecidos. As perdas se distribuíram da seguinte forma: 4 famílias recusaram a participação devido a cansaço dos pacientes e/ou familiares, que se mostraram desinteressados em agendar a entrevista para um segundo momento; 4 pacientes faleceram antes da data prevista para a coleta dos dados; 3 pacientes não puderam ser contatados, pois não compareceram às consultas agendadas e seus telefones encontravam-se desatualizados nos registros hospitalares.

\subsection{Descrição dos casos clínicos}

\section{Caso 1:}

E, 13 anos, sexo masculino, pardo, natural e procedente de São Paulo-SP.

Mora com a mãe, o padrasto e as irmãs, de 16 e 4 anos. Às vezes, passa um fim de semana com o pai, tendo pouco contato com o mesmo. Sua mãe conta que havia muitas brigas no casal durante a gestação de Emerson e que seu desenvolvimento neuropsicomotor (DNPM) foi normal até completar 1,5 anos, quando começou a apresentar os primeiros sinais de doença. A separação do casal se deu pouco tempo após o nascimento.

E frequentou a escola até a $4^{\mathrm{a}}$ série do EF, sendo que no momento da avaliação estava fora dela por conta dos sintomas e do tratamento. Repetiu todas as séries devido às faltas e não gostava de ir. Mãe diz que ele não se interessa e tem dificuldades para aprender.

Tem alguns amigos no bairro, com quem brinca de carrinho e videogame. $\mathrm{O}$ relacionamento com a mãe e o padrasto é bom, assim como com a irmã mais velha. Não se dá muito bem com a irmã mais nova, principalmente devido a ciúmes.

Para o cuidado de E, a família conta com o suporte de avós e tios maternos.

Sente-se mal e triste quando percebe a diferença entre si mesmo e as outras crianças, por exemplo, ao ver que os outros crescem e ele, não. É mais medroso e ansioso que as irmãs, preocupa-se com o que os outros pensam dele. Há 10 meses, está mais triste, sem fazer as coisas das quais gosta, irritado. Pensa em morrer (de certa forma, como um alívio), rói as unhas e 
é bastante teimoso, segundo a mãe. Mãe se preocupa por achar que E está com depressão e chegou a levá-lo a psiquiatra que o medicou, mas não se adaptou à droga prescrita (anorexia) e houve interrupção do seguimento. A mãe também está em tratamento para depressão.

Já fez cirurgias para hérnias umbilical e inguinal e usa amlodipina ${ }^{4} 12,5 \mathrm{mg} / \mathrm{dia}$ devido a Hipertensão Arterial Sistêmica (HAS). Faz terapia de reposição enzimática ${ }^{5}$ no Instituto da Criança (SP).

Na ocasião da avaliação, estava incapacitado de andar e de enxergar, com alguma perda auditiva, embora tenha sido possível conversar com ele, com auxílio da mãe. Apresentavase vigil, colaborativo, orientado, sem alterações de atenção ou memória, com pensamentos de morte, humor deprimido e discreta lentificação psicomotora.

Diagnóstico multiaxial, segundo o DSM-IV-TR (APA, 2000):

Eixo I: Transtorno Depressivo Maior, subtipo melancólico, episódio atual grave; enurese (secundária), encoprese (secundária)

Eixo II: Déficit grave (nível adaptativo geral: 29), compatível com retardo mental grave.

Eixo III: Mucopolissacaridose tipo I (S. Hurler)

Eixo IV: Família organizada, dinâmica estável

Eixo V: CGAS: 30 (incapaz de funcionar em quase todas as áreas)

Comentário clínico: a entrevista com E e sua mãe foi tranqüila, com ambos mostrando-se bastante colaborativos. No entanto, foi um momento difícil, pois havia uma angústia permeando a entrevista e o contato com um menino que, de fato, achava que morrer seria um alívio, deixou uma sensação de tristeza após encerrarmos.

\section{Caso 2:}

ML, 13 anos, sexo feminino, parda, natural e procedente de Cuiabá-MT.

\footnotetext{
${ }^{4}$ Para esclarecimentos sobre as medicações citadas, consultar a seção "medicações citadas" após o glossário.

${ }^{5}$ A terapia de reposição enzimática (TRE) consiste na infusão endovenosa semanal da enzima específica deficiente, por tempo indeterminado, sendo o tratamento mais eficiente na modificação da evolução da doença até o momento. Está disponível para as MPSI, MPSII e VI (Paula, Kim \& Albano, 2010).
} 
Mora com a mãe, não tem irmãos.

Está fora da escola desde os 11 anos porque "não aprendia nada”. Mãe diz que "só fez o jardim”. No entanto, quando ia à escola, dava-se bem com alguns colegas, embora não tivesse nenhum melhor amigo. Não tem amigos na vizinhança, sofre "muito preconceito". Gosta muito de uma prima de idade próxima, embora a mãe diga que ela não consegue brincar com outras pessoas. Fala muito sozinha (“ela sempre gostou de conversar sozinha”) e gosta de ver TV (desenhos e novela), ouvir música e de brincar com bonecas.

Tem relacionamento satisfatório com os pais, embora a mãe a descreva como provocativa com ambos e agressiva com ela própria (mas não com o pai). Não gosta de ver a mãe triste ou doente e sente-se desconfortável em situações sociais. A mãe interpreta isto como vergonha.

$\mathrm{Na}$ época do diagnóstico, ao redor dos 6 anos, mãe consultou psicóloga para si e para a filha, sendo que esta fez acompanhamento psicológico dos 6 aos 8 anos de idade: não saía mais de casa devido a vergonha. Nessa época, queixava-se de diversas dores (de cabeça, nas pernas, nas costas) na hora de dormir. Há 7 anos, presenciou cenas de violência doméstica entre os pais e ficou muito impressionada com isso, pensando frequentemente na situação. Foi um episódio isolado. Há 6 meses, os pais se separaram e uma de suas avós faleceu, sendo que a partir de então ML tornou-se triste, calada, chorosa, mais agressiva e com menor interesse nas coisas de que gosta. Há 3 meses, não controla mais as fezes. Nessas ocasiões, fica nervosa e chama a mãe ("ela fica envergonhada"). Mãe a descreve como muito impulsiva, especialmente em casa., muito dependente, ansiosa, sendo que há ocasiões em que chora ou ri com muita facilidade, tem crises de birra e torna-se muito teimosa.

Mãe diz que a filha vem se acostumando com a situação, com diminuição gradual dos sintomas. Há um relato de 15-20 dias, logo após esse período de maior tristeza (que durou cerca de 1 mês), em que ela "estava tão feliz que até a TV a fazia sorrir".

Faz reposição enzimática em Cuiabá desde os 10 anos e seguimento ambulatorial no Instituto da Criança de SP. Trata-se para HAS com captopril 37,5mg/dia. Sofreu cirurgia de coluna aos 5 anos (parou de andar aos 4 anos, o médico achou que era da coluna).

Na ocasião da avaliação, locomovia-se com cadeira de rodas e não respondeu à entrevista, sendo que a mesma foi conduzida exclusivamente com a mãe.

Diagnóstico Multiaxial: 
Eixo I: Autismo Infantil (ATA: 12, CARS: 35); Transtorno de Ajustamento com Humor Depressivo; Encoprese (secundária)

Eixo II: Déficit grave (nível adaptativo geral: 32), compatível com retardo mental grave

Eixo III: Mucopolissacaridose tipo I (S. Hurler)

Eixo IV: Família desorganizada, dinâmica satisfatória, instável

Eixo V: CGAS: 30 (incapaz de funcionar em quase todas as áreas)

Comentário clínico: desta entrevista, a impressão que ficou foi a de que a mãe negava boa parte das dificuldades da filha, emprestando significados que, no contato pessoal com a paciente, não pude perceber.

\section{Caso 3:}

R, 8 anos, sexo masculino, natural e procedente de São Paulo-SP.

Mora com os pais, não tem irmão.

Mãe preocupa-se muito com o futuro de seu filho. Ele frequenta psicopedagoga e fonoterapia desde o início de 2011 devido a dificuldades de leitura. Frequenta escola normal e está no $2^{\circ}$ ano do EF, sendo que o está cursando pela segunda vez a pedido da mãe. Tem problemas com os colegas na escola, sendo alvo de gozações e provocações. É amigo dos primos e gosta de TV, videogame, futebol, natação e de passear. Ainda urina na cama, ficando envergonhado e pedindo desculpas quando percebe o que aconteceu. É um pouco impaciente, perdendo o controle com facilidade e roendo as unhas. Até hoje, dorme no quarto dos pais.

Passou por cirurgias para correção de fimose (1 ano) e extração das adenoides (3a5m). A gestação teve que ser interrompida na $36^{\mathrm{a}}$ semana, devido a oligoâmnio. $\mathrm{R}$ nasceu com baixo peso $(2400 \mathrm{~g})$ e pé torto congênito, corrigido com gesso. Faz reposição enzimática no Instituto da Criança.

Durante a avaliação, realizada na residência de $\mathrm{R}$, o mesmo ficou presente enquanto eu conversava com a mãe, intervindo algumas vezes. No entanto, quando me dirigi 
diretamente a ele, pedindo que respondesse a algumas perguntas, fugiu para seu quarto e não saiu dali até que eu deixasse o local.

\section{Diagnóstico Multiaxial:}

Eixo I: Enurese noturna (primária)

Eixo II: Déficit leve (nível adaptativo geral: 67), compatível com retardo mental leve

Eixo III: Mucopolissacaridose tipo I (S. Scheie)

Eixo IV: Família organizada, dinâmica satisfatória, estável

Eixo V: CGAS: 70 (alguma dificuldade em uma única área)

Comentário clínico: esta entrevista foi realizada na residência da família, após bastante insistência de minha parte. Apesar disso, fui bem recebida e a mãe de $R$ fez questão de fazer com que eu me sentisse à vontade. Pareceu-me uma família bem estruturada e cuidadosa, embora a mãe tendesse a uma proteção excessiva do filho.

\section{Caso 4:}

LB, 7 anos, sexo feminino, natural e procedente de Itápolis-SP.

Mora com ambos os pais, não tendo irmãos.

Frequenta o primeiro ano do Ensino Fundamental, como aluna de inclusão. A escola fornece auxiliar de ensino que permanece com a criança durante todo o período de aulas. Ainda assim, os pais se queixam de que a escola tem muitas dificuldades para lidar com L, sendo que notam que a filha é "deixada de lado" em diversas ocasiões (como, por exemplo, quando dão algum material extra para os outros alunos e não o fornecem para L). Por outro lado, contam que os colegas de classe têm bom relacionamento com L, acolhendo-a e ajudando-a quando necessário.

Excetuando-se as crianças da escola, tem contato apenas com alguns primos de idade próxima, com bom relacionamento com eles. Quando próxima dos mesmos, gosta de ver TV e ouvir música, porém não se envolve em brincadeiras e jogos recíprocos. 
O relacionamento familiar é bom, sendo que os avós participam do cuidado com $\mathrm{L}$ quando se faz necessário. Os pais participam, também da Associação Paulista de Mucopolissacaridoses, uma organização de pais e familiares de pacientes acometidos por essas síndromes.

Do ponto de vista do desenvolvimento, os pais negam qualquer intercorrência durante a gravidez, o parto e o puerpério. Por outro lado, preocupavam-se com L desde os primeiros meses, devido à macrocefalia, mas foi apenas com um ano de idade que o pediatra notou maiores alterações e iniciou uma investigação. Teve atraso na aquisição dos marcos do desenvolvimento, sendo que andou com 2 anos, nunca controlou esfíncteres e fala palavras isoladas ou combinadas duas a duas.

Segundo os pais, aos 4 anos apresentou quadro de hidrocefalia, tendo sido submetida a cirurgia aos 4 anos, com permanência em Unidade de Terapia Intensiva por diversos dias. Após essa ocasião, L passou a apresentar graves alterações do comportamento (agitação, auto e heteroagressividade, resistência a novidades) e perdeu capacidades antes adquiridas ("ela precisou aprender tudo de novo: comer, andar, falar").

Apresenta quadro de glaucoma e foi submetida a cirurgia para Síndrome do Túnel do Carpo aos 5 anos.

Atualmente, faz reposição enzimática no Hemocentro de Ribeirão Preto-SP e seguimento clínico na Santa Casa de Itápolis. Em uso de neuleptil 4\% 10 gotas e risperidona 1mg à noite, para controle dos sintomas comportamentais, com boa resposta medicamentosa. Também tem acompanhamento de fisioterapia, terapia ocupacional, psicologia e fonoaudiologia em sua cidade natal.

\section{Diagnóstico Multiaxial:}

Eixo I: Transtorno Mental Orgânico; Enurese (primária); Encoprese (primária)

Eixo II: Déficit Grave (nível adaptativo geral: 35), compatível com retardo mental grave

Eixo III: Mucopolissacaridose tipo I

Eixo IV: Família organizada, dinâmica satisfatória, estável.

Eixo V: CGAS:35 (limitação importante no funcionamento em várias áreas)

Comentário clínico: este casal veio com a filha especialmente para participar desta entrevista. Assim, mostraram-se bastante motivados e tiraram diversas dúvidas a respeito 
do quadro comportamental da filha. Quando conversamos sobre o tópico autismo, a mãe chegou a ter lágrimas nos olhos, temerosa de que a filha pudesse receber também este diagnóstico. Falaram sobre a impossibilidade ter outros filhos devido à atenção exigida por L e sobre a decisão da mãe de estudar pedagogia (embora isto não tenha sido explicitamente declarado, ficou claro que uma das motivações é o descontentamento com a escola de L).

\section{Caso 5:}

L, 16 anos, sexo masculino, natural e procedente de São Paulo-SP.

Mora com ambos os pais, não tem irmãos.

Está fora da escola, tendo entrado na escola especial aos 12 anos de idade. Fez a primeira série nesse local e depois passou para a escola regular, tendo frequentado até a $3^{\mathrm{a}}$ série do Ensino Fundamental. Nunca teve bom rendimento e os professores reclamavam de falta de atenção e de L ser “devagar”. L acabou por não querer ir mais, sendo que a mãe acredita que isso se deveu a outras crianças caçoarem dele.

Tem alguns colegas na vila em que moram, mas nenhum melhor amigo. Todos são bem mais novos do que ele. Brinca de bolinha de gude, pipa, futebol e bicicleta, quando os outros o aceitam, porém é alvo de gozação por parte das crianças.

Atualmente está mais rebelde com a mãe e a família não é próxima de outros parentes. Como lazer, gosta de ver filmes e jogar videogame. Teve atraso no controle das fezes. Mãe diz que ele tem pouco apetite. Tem pouca capacidade para sem concentrar e, às vezes, chora muito facilmente, é impulsivo e parece bastante infeliz. Tende a ser mal-humorado e a agredir crianças menores que ele. Além disso, diz que a conversa de L, muitas vezes, é "sem pé nem cabeça”.

Passou por procedimentos cirúrgicos para correção de hérnias umbilical e inguinais. Faz uso de captopril $25 \mathrm{mg} 8 / 8 \mathrm{~h}$ e furosemida $20 \mathrm{mg}$ para controle de HAS. Faz reposição enzimática no ICr. Durante a gestação mãe foi tabagista de $1 / 2$ maço por dia. Teve atraso de desenvolvimento neuropsicomotor, tendo sentado sem apoio aos 10 meses e andado após os dois anos de idade. Mãe acha que ele foi um bebê muito retraído devido às diversas 
internações hospitalares. A mãe também se preocupa pelo fato de L ter uma "mentalidade muito de criança".

Durante a avaliação, L mostrou-se afável e colaborativo, embora tenha tido alguma dificuldade para compreender o que era esperado dele.

\section{Diagnóstico Multiaxial:}

Eixo I: Sem diagnóstico psiquiátrico atual

Eixo II: Déficit leve (nível adaptativo geral: 61), compatível com retardo mental leve

Eixo III: Mucopolissacaridose tipo I (S. Hurler-Scheie)

Eixo IV: Família organizada, dinâmica satisfatória, estável

Eixo V: CGAS: 35 (limitação importante no funcionamento em várias áreas)

Comentário clínico: L e a mãe foram muito receptivos, sendo que a entrevista transcorreu num clima agradável. No caso desta dupla, a mãe percebe claramente a limitação do filho e sua superproteção relaciona-se a isto, apesar de limitar algumas possibilidades do mesmo.

\section{Caso 6:}

G, 9 anos, sexo masculino, natural de Belém-PA, procedente de Guarulhos-SP. Mora com o pai e a mãe.

Frequenta o $3^{\circ}$ ano do $\mathrm{EF}$, acompanhando bem a escola. Tem amigos e não é vítima de gozações ou provocações. Gosta muito da aula de Educação Física, de TV, computador e jogar queimada. Rói as unhas quando ansioso.

Faz reposição enzimática no Hospital Infantil de Guarulhos e seguimento de insuficiência de valva cardíaca no INCOR. Ficou internado por pneumonia aos 8 anos. Mãe se preocupa pelo fato de $\mathrm{G}$ ser muito quieto e fechado "como o pai". Tem um primo e um tio materno com MPS II no Pará, sendo que o primo faz acompanhamento com psiquiatra, mas a mãe não sabe por quê. 
Durante a avaliação, realizada numa das suas primeiras seções de reposição enzimática, G mostrou-se bem humorado e colaborativo, respondendo a todas as perguntas de forma adequada.

\section{Diagnóstico Multiaxial:}

Eixo I: Sem diagnóstico psiquiátrico atual

Eixo II: Nível adaptativo moderadamente baixo (nível adaptativo geral: 67), compatível com inteligência limítrofe

Eixo III: Mucopolissacaridose tipo II (S. Hunter)

Eixo IV: Família organizada, dinâmica satisfatória, estável

Eixo V: CGAS: 90 (bom funcionamento em todas as áreas)

Comentário clínico: esta foi a entrevista mais fácil de todas as realizadas. Tanto a mãe como a criança foram muito simpáticos e receptivos. A mãe pareceu-me, inclusive, excepcionalmente tranqüila, quando comparada a todas as outras entrevistadas. Talvez isso se devesse ao fato de o diagnóstico de seu filho ser recente, ou então, ao fato de ela possuir outros parentes já acometidos e isso diminuir um pouco a ansiedade frente ao desconhecido.

\section{Caso 7:}

GS, 7 anos, sexo masculino, natural e procedente de Guarulhos-SP.

Mora com os pais e dois irmãos mais novos, sendo que os avós e uma prima moram na casa de baixo.

Frequenta $1^{\circ}$ ano do EF, não tendo sido notadas diferenças entre ele e os colegas em termos de desempenho. Não tem muitos amigos, mas gosta de jogar bola e brincar de pegapega com os que tem. Além disso, gosta de TV, computador e esportes como futebol e basquete. Tem ataques de birra com frequência. Ainda chupa o dedo e acorda durante a noite. É bastante impulsivo. Aos 6 anos, passou no psicólogo uma vez, mas não voltou. Tem uma prima pelo lado do pai que tem autismo e retardo mental. 
Faz reposição enzimática no Hospital Infantil de Guarulhos. Passou por cirurgias para correção de hérnia umbilical e fimose e para extração de amígdalas e adenoides. Ao nascimento, ficou em UTI neonatal por 26 dias, porém a mãe não soube dar mais detalhes.

Durante a avaliação, GS mostrou-se bastante ativo e inquieto, tendo dificuldade em manter a atenção no que lhe era perguntado. Apesar disso, pareceu bastante interessado enquanto eu conversava com sua mãe.

\section{Diagnóstico Multiaxial:}

Eixo I: Sem diagnóstico psiquiátrico atual

Eixo II: Nível adaptativo adequado (nível adaptativo geral: 88), compatível com inteligência normal

Eixo III: Mucopolissacaridose tipo II (S. Hunter)

Eixo IV: Família organizada, dinâmica satisfatória, estável

Eixo V: CGAS: 75 (não mais que uma limitação leve no funcionamento)

Comentário clínico: a entrevista transcorreu sem incidentes, sendo que a mãe tinha que se dividir entre a atenção ao filho, bastante inquieto, e ao nosso diálogo. Não houve nada de especialmente marcante nesta ocasião.

\section{Caso 8:}

K, 9 anos, sexo masculino, natural e procedente de Guarulhos-SP.

Mora com os pais e duas irmãs mais velhas.

Está fora da escola, pois a mesma diz não possuir profissional habilitado para o acompanhamento do mesmo. Chegou a frequentar "sala de inclusão" nos anos anteriores, mas professoras reclamavam de que ele é muito agitado e não pode ficar sozinho. Além disso, mãe diz que o filho era alvo de preconceito e agressões verbais por parte das outras crianças. Não se relacionava bem com elas e batia quando desagradado. Em casa, é mais tranquilo, não tendo problemas com os familiares. Gosta de TV, olhar a rua e as pipas que os outros meninos empinam, passear, jogar bola e andar de bicicleta. Voltou a urinar nas roupas e na cama há dois anos, ficando incomodado com isso. O mesmo acontece com as fezes. É muito agitado, desatento 
e impulsivo, estabelece pouco contato com as pessoas ("ele nem liga para o que a gente fala"). Às vezes, tem crises de choro sem motivo aparente, que duram cerca de 5 minutos: fica mais nervoso e agressivo se alguém quer se aproximar dele. Em outras ocasiões, "ri do nada". Come papéis e borracha, sono de má qualidade.

Teve alteração de desenvolvimento da linguagem, sendo que até hoje não fala frases. A mãe preocupa-se com isso e com o fato de ele ser agitado e chorar com facilidade. Tem irmã com tricotilomania.

Faz reposição enzimática no Hospital Infantil de Guarulhos. Toma 10 gotas de neuleptil $4 \%$ à noite, para melhorar qualidade do sono e reduzir agitação. Fez cirurgias para extrair adenoides e amígdalas (2a6m) e corrigir hérnias inguinais e fimose (9a). Frequenta PS devido a episódios de broncoespasmo.

Durante a avaliação, K mostrou-se muito inquieto, sem estabelecer nenhuma forma de contato com qualquer pessoa além da mãe. Tentou, por diversas vezes, chamar sua atenção para que interrompesse a conversação comigo.

\section{Diagnóstico Multiaxial:}

Eixo I: Autismo infantil (ATA: 24, CARS: 35,5), Enurese (secundária), Encoprese (secundária)

Eixo II: Déficit grave (nível adaptativo geral: 26), compatível com retardo mental grave

Eixo III: Mucopolissacaridose tipo II (S. Hunter)

Eixo IV: Família organizada, dinâmica satisfatória, estável

Eixo V: CGAS: 35 (incapaz de funcionar em quase todas as áreas)

Comentário clínico: apesar da dificuldade causada pela extrema agitação de $K, a$ mãe mostrou-se disponível e interessada na entrevista. Seu relato provocou, em mim, uma reflexão a respeito da falta de informação a respeito das alterações de comportamento nessas crianças, pois em nenhuma ocasião algum profissional (da saúde ou da educação) aventou a possibilidade de que este menino fosse acometido por um transtorno de desenvolvimento específico, ficando todos os sintomas "por conta da síndrome”. De certa forma, para esta mãe

foi um alívio saber sobre a questão do Transtorno Invasivo de Desenvolvimento e receber um encaminhamento adequado para este problema (foi fornecido relatório e encaminhamento para o Centro de Atenção Psicossocial Infantil de Guarulhos (CAPSi). 


\section{Caso 9:}

AD, 3 anos, sexo masculino.

Mora com ambos os pais, também tendo uma babá como cuidadora. Pais relatam gravidez sem intercorrências, exceto uma suspeita de pé torto congênito. $O$ mesmo foi confirmado após o nascimento, tendo sido corrigido com botas gessadas até os 5 meses de idade. Embora os principais marcos de desenvolvimento motor tenham sido atingidos em idade dentro da normalidade, os pais descrevem A como "estabanado" e tendo algumas dificuldades de equilíbrio, como cair e tropeçar com facilidade. Tem atraso na aquisição da fala, tendo dito suas primeiras palavras aos 2 anos e apenas agora, aos 3 anos, tem iniciado as primeiras frases de duas palavras.

A freqüenta pré-escola e pais afirmam que, apesar de ele ter interesse por estar próximo a crianças de sua idade, ele ainda não tem boa interação com elas. Aparentemente, sente-se mais confortável com crianças mais velhas e adultos.

Ainda não alcançou controle esfincteriano.

O diagnóstico de MPS foi feito há 1 mês, sendo que os pais estão bastante mobilizados por isto. Preocupam-se com o atraso de desenvolvimento e o futuro do filho, sendo que o mesmo está em tratamento fonoaudiológico há 2 meses.

Em paralelo, preocupam-se com crises freqüentes de birra, mostrando-se bastante permissivos em relação ao comportamento do filho.

A iniciará tratamento de reposição enzimática em breve.

\section{Diagnóstico Multiaxial:}

Eixo I: Sem diagnóstico psiquiátrico atual

Eixo II: Déficit leve (nível adaptativo geral: 60), compatível com retardo mental leve

Eixo III: Mucopolissacaridose tipo II

Eixo IV: Família estruturada, dinâmica insatisfatória, estável

Eixo V: CGAS: 55 (funcionamento variável com dificuldades esporádicas)

Comentário clínico: esta entrevista foi realizada logo após a realização do diagnóstico de MPS. Assim, estes pais estavam bastante inseguros e angustiados, buscando compreender o que isso implicará em suas vidas e na de seu filho. Além disso, foi uma entrevista tumultuada pelo fato de que a criança não respeitava limite algum, literalmente dando ordens a 
seus pais, que as obedeciam. Dessa forma, a conversa foi, também, palco de orientações para o manejo de crises de birra e comportamentos manipuladores que, em si, não fazem parte dos sinais e sintomas característicos da síndrome estudada.

\section{Caso 10:}

R, 13 anos, sexo feminino, natural e procedente de São Paulo-SP.

Mora com a mãe e um primo, pois os pais se separaram há 12 anos (quando a paciente tinha 1 ano). O pai dá pensão, mas não mantém nenhum contato com a filha. Tinha uma irmã gêmea, também portadora de MPSIII, que faleceu há 1 ano. Mãe conta que $\mathrm{R}$ teve desenvolvimento normal até os 5 anos de idade e refere que a tem achado mais "caída" desde o falecimento da irmã.

Está fora da escola, porém a mãe não informou se ela alguma vez a frequentou. Por outro lado, diz que $\mathrm{R}$ vai à APAE-SP diariamente para estimulação. $\mathrm{R}$ não sai de casa e não tem nenhuma relação interpessoal, à exceção da mãe e do primo que mora com elas.

Não controla esfíncteres, usando fraldas desde 2001. Tem sono entrecortado devido a apneia do sono. Tem crises epilépticas tonicoclônicas generalizadas, fazendo uso de fenobarbital 65 gotas a cada 12h. Alimenta-se por gastrostomia há 6 meses.

Durante a avaliação, foi muito difícil estabelecer contato com esta mãe, que se mostrou pouco disponível durante a entrevista, deixando de responder diversos itens do K-SADS (olhava para mim com uma expressão de que não lhe fazia nenhum sentido responder àquilo, já que a filha agora é totalmente dependente). $\mathrm{R}$ não manteve qualquer tipo de contato interpessoal durante a entrevista, exceto alguns (poucos) momentos de contato visual.

\section{Diagnóstico Multiaxial:}

Eixo I: Autismo infantil (ATA: 14, CARS: 31,5), Enurese (secundária), Encoprese (secundária)

Eixo II: Déficit Profundo (nível adaptativo geral: <20), compatível com retardo mental profundo

Eixo III: Mucopolissacaridose tipo III (S. Sanfilippo) 
Eixo IV: Família desestruturada, dinâmica insatisfatória, instável

Eixo V: CGAS: 10 (necessita de supervisão constante)

Comentário clínico: talvez esta tenha sido a entrevista mais difícil de todas as realizadas. A mãe, claramente, não via sentido nela e não aparentava motivação para participar. Por sua resistência, pude depreender a extrema angústia de ter uma filha nas condições da sua (cadeirante, epiléptica, autista), apenas aguardando pela morte da mesma, assim como ocorrera com sua outra filha um ano antes, e sem contar com qualquer forma de suporte. Para além disso, talvez também como uma forma de defesa, apresentava também uma recusa frente a qualquer tentativa de aproximação mais pessoal e afetiva, evitando falar sobre sentimentos $e$ preocupações a atendo-se aos fatos concretos. Não aceitou qualquer forma de suporte quando oferecido e pareceu realmente aliviada quando me retirei.

\section{Caso 11:}

W, 17 anos, sexo masculino, natural e procedente de São Paulo-SP.

Mora com os pais e a irmã mais velha (21 anos).

Frequenta o $3^{\circ}$ ano do Ensino Médio, com bom desempenho escolar. Nunca foi reprovado e os professores nunca se queixaram do aluno. Gosta de matemática e não gosta de biologia. Tem como melhor amigo um primo de idade próxima e diz ter bom relacionamento com a "turma" da escola. Apesar disso, diz sofrer porque o chamam de "aleijado". Tem bom relacionamento com a família e gosta de ver TV, ir a jogos de futebol e a festas. Não tem hobbies.

Mãe começou a notar mudanças físicas quando W tinha 2 anos de idade. Em relação a queixas atuais, a mãe diz preocupar-se muito quando o filho sai sem ela.

Desde pequeno, até completar 14 anos, conta que ficava com muito medo quando o pai viajava a trabalho, tendo dores de cabeça e outros sintomas físicos enquanto ele não voltava (Imaginava que ele poderia sofrer algum acidente). Isso o atrapalhava tanto quando estava em casa quanto quando ia para a escola. 
Há 9 anos, um tio querido faleceu em acidente de carro, sendo que $\mathrm{W}$ ficou muito perturbado por cerca de 1 mês: ficava pensando e falando no tio o tempo todo, tinha pesadelos e dificuldades para adormecer, ouvia o tio chamando por ele, chorava muito e não queria entrar na casa em que esse tio morava, deixando de fazer coisas que antes lhe eram prazerosas ou importantes.

Mãe teve sarampo no terceiro mês de gestação. Tem três tios paternos com MPS IV.

Faz uso de medicação anti-hipertensiva devido a HAS. Já passou por cirurgias: amigdalectomia e fimose.

Durante a avaliação, W mostrou-se muito acessível e colaborativo, seguro em suas respostas, sem nenhuma alteração no exame psíquico. (Foi o único sujeito a me passar seu e-mail para saber dos resultados do trabalho.)

\section{Diagnóstico Multiaxial:}

Eixo I: Sem diagnóstico psiquiátrico atual

Eixo II: Nível Adaptativo Adequado (nível adaptativo geral: 88), compatível com inteligência normal

Eixo III: Mucopolissacaridose tipo IV (S. Morquio)

Eixo IV: Família estruturada, dinâmica satisfatória, estável

Eixo V: CGAS: 85 (bom funcionamento em todas as áreas)

Comentário clínico: este encontro foi bastante leve e agradável. Ao contrário de outras famílias (e talvez devido à menor gravidade do quadro deste rapaz), esta parecia aceitar e lidar com alguma serenidade as limitações (predominantemente motoras) de W. Não há tanta superproteção e Wé bastante estimulado a alcançar maiores graus de independência, sem se deixar de respeitar seus limites.

\section{Caso 12:}

V, 12 anos, sexo masculino, natural e procedente de São Paulo-SP. 
Mora com a mãe, um irmão e uma irmã mais velhos. O pai foi assassinado há 1 ano e 8 meses, após discussão com um vizinho. Não há queixas ou preocupações em relação a V, porém passou por avaliação psicológica em 2011.

Frequenta o $7^{\circ}$ ano do EF como aluno de inclusão, mas mãe avalia que seu desempenho não é bom ("a diretora não repete"). Tem alguns amigos próximos, com quem gosta de jogar bola, videogame e andar de bicicleta. Por outro lado, sofre gozação por parte de alguns colegas da escola. Sente bastante falta do pai, sendo que na época de sua morte, falava muito nele, procurava-o pela casa, o via em alguns locais, perdeu o apetite e ficou mais "caído". Durante os quatro meses em que ficou assim, adoeceu algumas vezes (p.ex. gripes, resfriados). Mãe conta que ele é muito ansioso e rói as unhas.

Teve atraso no controle do esfíncter vesical, alcançando-o apenas aos 6 anos.

$\mathrm{Na}$ avaliação, mostrou-se afável e colaborativo, porém teve dificuldades de compreensão de algumas questões.

\section{Diagnóstico Multiaxial:}

Eixo I: Sem diagnóstico psiquiátrico atual

Eixo II: Déficit Leve (nível adaptativo geral: 64), compatível com retardo mental leve

Eixo III: Mucopolissacaridose tipo IV (S. Morquio)

Eixo IV: Família desestruturada, dinâmica satisfatória, estável

Eixo V: CGAS: 55 (funcionamento variável com dificuldades esporádicas)

Comentário clínico: a entrevista foi tranqüila e a criança concordou em participar, esforçando-se para responder às perguntas. Um pouco tímido no início, foi relaxando com o passar do tempo. A mãe, tendo passado pela perda súbita do marido, foi capaz de mobilizar seus próprios recursos para continuar a dar suporte para os filhos.

\section{Caso 13:}

JA, 15 anos, sexo masculino, natural e procedente de Pedra Preta-MT. 
Mora com os pais e o irmão de 13 anos. A mãe nega qualquer complicação durante a gravidez e o desenvolvimento de JA, exceto o fato de ter nascido de parto pélvico. Em sua cidade natal, fez acompanhamento com psicóloga na APAE dos 8 aos 9 anos.

Entrou na escola aos 5 anos, sendo que na ocasião teve bastante dificuldade para se adaptar, chorando e se recusando a afastar-se da mãe. Atualmente está na $4^{\mathrm{a}}$ série do EF, com desempenho regular. Repetiu um ano por faltas devido ao tratamento e ficou quatro anos afa stado da escola também por causa dele. No entanto, diz gostar da escola, especialmente de matemática. Tem um melhor amigo, porém diz ser alvo de gozação dos colegas por causa de sua dificuldade física. Tem bom relacionamento com a família e a vizinhança. Gosta de computadores e de ouvir música.

Uma única vez, aos 9 anos, furtou a merenda de um colega, mas a mãe não sabe dizer o porquê. Era uma criança ansiosa, mais preocupado que o irmão. Às vezes tinha dores de cabeça devido à ansiedade, mas não se queixava. Rói as unhas até hoje e a mãe o considera dependente demais.

Faz acompanhamento em diversos hospitais, sendo dois em São Paulo em um em Cuiabá, mais próximo de onde vive (Pedra Preta - MS). Já passou por 4 cirurgias ortopédicas de MMII, sendo a última há 4 anos.

Durante a avaliação, mostrou-se com bom contato e colaborativo, respondendo adequadamente às perguntas, mas recorrendo à mãe quando se sentia inseguro.

\section{Diagnóstico Multiaxial:}

Eixo I: Sem diagnóstico psiquiátrico atual

Eixo II: Nível adaptativo moderadamente baixo (nível adaptativo geral: 70), compatível com inteligência limítrofe

Eixo III: Mucopolissacaridose tipo IV (S. Morquio)

Eixo IV: Família organizada, dinâmica satisfatória, estável

Eixo V: CGAS: 75 (não mais que uma limitação leve no funcionamento)

Comentário clínico: este menino parece bem mais novo do que de fato é, tanto por sua apresentação física, quanto por seu comportamento infantilizado. Um alto grau de superproteção pode ser, ao menos em parte, responsável por isto, já que isto fica claro na relação desta dupla de mãe e filho. 


\section{Caso 14:}

D, 15 anos, sexo feminino, natural e procedente de São José do Rio Preto-SP.

Mora com a mãe, o padrasto e uma irmã de criação. O pai, o irmão e uma meiairmã moram no mesmo município, em outra residência.

Frequenta o nono ano do Ensino Fundamental, tendo bom desempenho segundo os pais. A paciente declara ter mais dificuldades em Matemática e gostar muito de Ciências.

Apesar de não ter melhores amigos, tem bom relacionamento com os colegas na escola e na vizinhança. Relata, apenas, uma discussão isolada com menina da escola. Suas atividades preferidas são navegar na internet, ouvir música e participar das aulas de teatro em sua escola.

Excetuando-se as dificuldades motoras decorrentes do comprometimento osteoarticular, pais relatam que o desenvolvimento de D transcorreu dentro dos limites da normalidade até o presente momento. A identificação de MPS foi feito ainda quando era bebê, pois uma fisioterapeuta notou deformidade nas mãos da menina e iniciou-se a pesquisa diagnóstica.

\section{Diagnóstico Multiaxial:}

Eixo I: Sem diagnóstico psiquiátrico atual

Eixo II: Déficit leve (nível adaptativo geral: 67), compatível com retardo mental leve

Eixo III: Mucopolissacaridose tipo IV

Eixo IV: Família organizada, dinâmica satisfatória, estável

Eixo V: CGAS: 85 (bom funcionamento em todas as áreas)

\section{Caso 15:}

C, 2 anos, sexo feminino, natural e procedente de São Paulo-SP. Mora com os pais e a irmã mais velha (A). 
Ainda não vai à escola. Gosta muito de um priminho de 3 anos e costuma brincar com bonecas e bola. Também gosta de dançar e ver TV. Mãe a acha impulsiva e inquieta. Tem algumas crises de birra. Range os dentes durante o sono.

Faz reposição enzimática no ICr. Excetuando-se por infecção urinária no período neonatal, não teve intercorrências clínicas até o momento.

$\mathrm{Na}$ avaliação, mostrou-se ativa e curiosa, recorrendo à mãe como figura de segurança.

\section{Diagnóstico Multiaxial:}

Eixo I: Sem diagnóstico psiquiátrico atual

Eixo II: Nível Adaptativo Moderadamente Baixo (nível adaptativo geral: 81), compatível com inteligência limítrofe

Eixo III: Mucopolissacaridose tipo VI (S. Maroteaux-Lamy)

Eixo IV: Família organizada, dinâmica satisfatória, estável

Eixo V: Não se aplica

Comentário clínico: aparenta ser uma menina de dois anos relativamente saudável, apesar de um pouco menos ativa que as crianças de mesma idade em geral. Não se pode esquecer, contudo, que o ambiente hospitalar e a medicação endovenosa podem, por si só, justificar esta observação. A mãe, tendo que lidar com duas filhas portadoras de MPS em reposição enzimática, obviamente pareceu-me cansada, mas esperançosa e relativamente tranqüila.

\section{Caso 16:}

AI, 10 anos, sexo feminino, natural e procedente de São Paulo-SP.

Mora com os pais e a irmã mais nova (C), também acometida por MPS VI.

Mãe relata que AI se tornou mais nervosa há cerca de dois anos (coincidindo com o nascimento da irmã). Quando foi submetida à cirurgia cardíaca, aos 9 anos, recebeu acompanhamento psicológico durante a internação. Na época, teve muito medo de morrer. Desde os 7 anos, tornou-se mais retraída, evitando contato social e preocupando-se com o que as 
pessoas dirão se a olharem na rua. A mãe diz que AI é muito ansiosa, chora com facilidade, rói as unhas e é bastante teimosa e mal-humorada.

Frequenta $4^{\mathrm{a}}$ série do EF, sendo considerada uma boa aluna. Tem alguns amigos, especialmente na vizinhança, pois não se relaciona bem com os colegas da escola: eles a provocam e caçoam, dizendo que tem "olho grande". O relacionamento familiar é bom, havendo algumas brigas do casal. Em uma ocasião em que o casal ficou separado, quando a filha tinha 5 anos, AI ficou por mais de um ano tristonha e irritada. Gosta de dançar e brincar com as amigas da vizinhança.

Faz reposição enzimática no ICr. Teve duas internações por pneumonias e passou por cirurgias para a colocação de prótese mitral, para correção de glaucoma bilateral e de hérnia umbilical. Faz uso de marevan 2,5mg/dia, digoxina $0,25 \mathrm{mg} /$ dia, furosemida $40 \mathrm{mg} /$ dia, enalapril 7,5mg/dia e espironolactona. Apresentou episódio de infecção urinária no período neonatal.

Durante a avaliação, mostrou-se tímida e retraída, deixando que a mãe respondesse muitas coisas por ela. Ainda assim, não se mostrou negativista ou hostil.

\section{Diagnóstico Multiaxial:}

Eixo I: Fobia Social

Eixo II: Nível Adaptativo Adequado (nível adaptativo geral: 88), compatível com inteligência normal

Eixo III: Mucopolissacaridose tipo VI (S. Maroteaux-Lamy)

Eixo IV: Família estruturada, dinâmica satisfatória, estável

Eixo V: CGAS: 50 (interferência moderada no funcionamento)

Comentário clínico: a menina mostrou-se bastante insegura e retraída. A mãe teve que responder a maior parte das questões, embora AI não tenha tido problemas de compreensão. Conforme o comentário da paciente 12, esta é uma família sobrecarregada por duas crianças portadoras de MPS. Ainda assim, aparentemente possuem recursos suficientes para lidar de forma satisfatória com a situação. 


\section{Caso 17:}

A, 7 anos, sexo masculino, procedente de São Paulo-SP.

Mora com o pai e duas irmãs mais velhas na casa dos tios. A mãe continuou no Nordeste com os outros quatro filhos, sendo que uma irmã mais velha de A faleceu devido ao mesmo problema do menino. Assim, A veio para São Paulo para se tratar.

Iniciou $1^{\circ}$ ano do EF, sendo que as professoras se queixam de que ele não obedece e corre muito pela sala de aula. Tem um colega na vizinhança, que o visita em casa, porém o relacionamento na escola é ruim: o xingam de "cabeção".

A tia conta que ele "não quer saber da mãe", mas que se relaciona muito bem com o pai e com ela própria. Gosta de atividades como TV, videogames e carrinhos.

Teve um atraso no desenvolvimento, percebido inicialmente como um atraso de fala. A tia refere que, há um ano, ele está mais nervoso, irritado, sensível e respondão, ao contrário do que era antes. Nunca controlou esfíncter vesical, mas não reclama, embora a tia ache que ele não se sente bem por precisar dormir de fraldas.

Tende a "inventar histórias" e já furtou pequenos objetos dos amigos em algumas

ocasiões (p. ex. lápis e carrinhos). É bastante dependente e medroso, sendo que a família nunca o deixa dormir sozinho (tia acha que ele iria chorar). Tem medo de escuro. O sono é agitado e de má-qualidade, provavelmente devido a apneia do sono (tia refere roncos). Preocupa-se muito com sua altura, comparando-se com outros meninos de sua idade. Tem mania de se esconder ou fugir em situações inapropriadas e não mistura diversos tipos de alimentos. Range muito os dentes. Tem crises de birra quando contrariado.

A usa enalapril 2,5mg/dia para controle de HAS e ficou internado apenas uma vez, aos três anos de idade, sendo que foi após a mesma que veio para SP. Faz reposição enzimática no ICr.

$\mathrm{Na}$ avaliação, A tentou evitar o contato inicialmente, mostrando-se bastante tímido. No entanto, com o passar do tempo, foi relaxando e tornou-se mais participativo.

\section{Diagnóstico Multiaxial:}

Eixo I: Enurese noturna (primária) 
Eixo II: Nível Adaptativo Moderadamente Baixo (nível adaptativo geral: 79), compatível com inteligência limítrofe

Eixo III: Mucopolissacaridose tipo VI (S. Maroteaux-Lamy)

Eixo IV: Família estruturada, dinâmica insatisfatória, estável

Eixo V: CGAS: 60 (funcionamento variável com dificuldades esporádicas)

Comentário clínico: esta entrevista foi realizada com a tia paterna do paciente. A mesma mostrou-se um pouco receosa de participar, alegando não saber informar sobre o sobrinho e desculpando-se diversas vezes. No entanto, durante o desenrolar do diálogo, foi relaxando e participando com maior naturalidade. Ficou aparente, em seu discurso, um certo ressentimento em relação à mãe de A, embora não o tenha enunciado claramente.

\section{Caso 18:}

D, 16 anos, sexo feminino, natural e procedente de Guarulhos-SP.

Mora com os pais, duas irmãs e um irmão, todos mais velhos.

Segundo a mãe, teve desenvolvimento normal até os 3 anos de idade e, depois, começou a "ficar com as juntas duras". Frequentou a escola até há dois anos, quando os pais a tiraram. Contam que, inicialmente, ia melhor, mas seu desempenho escolar foi caindo ao longo do tempo (a mãe relaciona a queda de rendimento a uma perda visual).

Não tem amigos próximos, mas gosta muito de conversar e relaciona-se bastante bem com a família. Também gosta de ouvir música. A mãe não apresentou queixas em relação à filha e diz que a filha fala com alguma frequência que "nunca vai morrer".

D faz uso de carvedilol devido a HAS e foi internada aos 10 anos por uma pneumonia. Faz reposição enzimática no Hospital Infantil de Guarulhos.

$\mathrm{Na}$ avaliação, mostrou-se tímida, porém colaborativa. Teve dificuldades de compreensão das questões. Bastante pueril.

\section{Diagnóstico Multiaxial:}

Eixo I: Sem diagnóstico psiquiátrico atual 
Eixo II: Déficit Grave (nível adaptativo geral: 27), compatível com retardo mental grave

Eixo III: Mucopolissacaridose tipo VI (S. Maroteaux-Lamy)

Eixo IV: Família estruturada, dinâmica satisfatória, estável

Eixo V: CGAS: 50 (interferência moderada no funcionamento)

Comentário clínico: esta avaliação me surpreendeu pois, embora eu soubesse a idade da paciente, por diversas vezes observei-me conversando com uma menina de 5 ou 6 anos. A atitude infantil, a baixa estatura, as roupas e o modo como a mãe a tratava compuseram esse cenário. Ainda assim, não é algo usual na prática diária. Para além disso, tivemos um bom contato, leve e dinâmico, sempre deixando-se evidenciar a superproteção materna em relação à filha.

\section{Caso 19:}

GH, 5 anos, sexo masculino, natural e procedente de Guarulhos-SP.

Mora com a mãe, dois irmãos mais velhos e o avô materno. Pais se separaram após o diagnóstico da doença ("ele não aceitou”). Sua gravidez foi turbulenta, pois o casal demorou para engravidar, o pai era usuário de drogas e houve situações de violência (física) durante a gravidez, sendo que a mãe chegou a ter um Trabalho de Parto Prematuro, que foi controlado com o uso de medicação.

Teve um atraso de desenvolvimento, especialmente de linguagem, desde bebê (sentou aos 9 meses, andou aos 2 anos, disse a primeira palavra aos 3 anos). Mãe se queixa de o filho ser muito agitado, teimoso e rebelde.

GH frequenta a pré-escola, sendo que a professora diz que ele "acompanha quase tão bem quanto os outros”. Tem prazer em ir à escola. Não tem problemas com os colegas, exceto por um episódio em que bateram nele. Tinha uma melhor amiga, porém ela mudou-se para outra escola e perderam contato.

Mãe relata ter um bom relacionamento com o filho, mas acha que não sabe colocar limites e é manipulada por ele. Tem pouco contato com o pai, fica mal (triste) por cerca de dois 
dias quando o visita e diz que não quer voltar. A família já esteve envolvida com o Conselho Tutelar, quando ficaram sem onde morar, mas isso foi antes de GH nascer.

Como lazer, gosta de ver TV.

Presenciou episódio de violência doméstica com 1,5 ano, porém aparentemente não houve impacto significativo.

Há três meses, voltou a urinar na cama, ficando angustiado com isso. Também ficou mais agressivo depois que os pais se separaram (há 2 anos) e começou a frequentar hospitais com frequência (há 1 ano, quando começou TRE), chegando a bater e morder os familiares quando frustrado e a ter ataques de raiva, onde quebra, rasga e furta coisas. Mãe também diz que ele é mentiroso e provocativo, mais que os colegas ou seus irmãos. Ao mesmo tempo, é inseguro na hora de dormir, pedindo que a mãe se deite com ele. Rói as unhas.

Faz reposição enzimática no Hospital Infantil de Guarulhos.

Durante a avaliação, não saiu de perto da mãe, porém recusou-se a conversar quando me dirigia a ele.

\section{Diagnóstico Multiaxial:}

Eixo I: Transtorno Oposicional Desafiador, Enurese Noturna (secundária)

Eixo II: Déficit Leve (nível adaptativo geral: 66), compatível com retardo mental leve

Eixo III: Mucopolissacaridose tipo VI (S. Maroteaux-Lamy)

Eixo IV: Família estruturada, dinâmica insatisfatória, estável

Eixo V: CGAS: 55 (funcionamento variável com dificuldades esporádicas)

Comentário clínico: esta criança apresentava, claramente, dificuldades emocionais importantes. A mãe, por seu lado, também demonstrava bastante dificuldade em lidar com os comportamentos do filho, sendo muito permissiva e inconsistente na apresentação de regras e limites. No entanto, foi uma das que recusou encaminhamento para atendimento especializado. 


\section{Caso 20:}

T, 11 anos, sexo feminino, natural e procedente de Nova Rezende-MG.

Mora com os pais e as irmãs, de quatorze e dezesseis anos.

Frequenta o quarto anos do Ensino Fundamental. Repetiu o segundo ano, devido a faltas excessivas por conta da doença. Segundo a mãe, tem desempenho regular, por faltar muito às aulas (pelo menos uma vez por semana).

$\mathrm{T}$ tem uma melhor amiga e bom relacionamento com os colegas da escola e da vizinhança. Como atividades preferidas, diz que gosta de jogar bola, mexer no computador e conversar, além de ler (estava com um livro durante a infusão enzimática).

O relacionamento familiar é bom, embora a mãe revele que a doença da filha tenha tido um impacto negativo sobre sua situação conjugal ("não é mais como era antes”).

$\mathrm{O}$ diagnóstico de $\mathrm{T}$ foi feito aos 5 anos, devido a pneumonias de repetição, aumento do volume abdominal e deformidades nas mãos. No que se refere ao desenvolvimento como um todo, a mãe nega ter notado diferenças durante a vida de sua filha.

Fez extração de amígdalas e adenóides aos 5 anos de idade.

Atualmente, faz reposição enzimática no Hemocentro de Ribeirão Preto-SP e usa captopril $12,5 \mathrm{mg} / \mathrm{dia}$.

\section{Diagnóstico Multiaxial:}

Eixo I: sem diagnóstico psiquiátrico atual

Eixo II: Nível adaptativo moderadamente baixo (nível adaptativo geral: 76), compatível com inteligência limítrofe

Eixo III: Mucopolissacaridose tipo VI

Eixo IV: Família organizada, dinâmica satisfatória, estável

Eixo V: CGAS: 80 (Não mais que uma limitação leve no funcionamento)

Comentário clínico: esta foi uma entrevista muito fácil, sendo que tanto a mãe quanto a criança mostraram-se dispostas e bem-humoradas. Apesar das dificuldades em se deslocar para um outro município uma vez por semana para realizar as sessões de reposição enzimática, a melhora na qualidade de vida observada desde o início da mesma faz com que a dupla encare a situação com otimismo. 


\section{Caso 21:}

L, 7 anos, sexo masculino, natural de São Paulo- SP, procedente de Ribeirão Preto-SP.

Mora com os avós maternos, pais separados, moram em Campinas (pai) e Barueri (mãe). Tem cinco meio-irmãos, dois por parte de mãe e três por parte de pai. Mora com os avós desde os 9 meses de idade ("nós vimos que eles não estavam cuidando direito e resolvemos pegá$10 ")$.

Freqüenta primeiro ano do Ensino Fundamental pela segunda vez, pois avós resolveram mudar-se par Ribeirão Preto no último ano e consideraram que a mudança de município e o maior afastamento dos pais poderiam causar prejuízos no desempenho escolar de L.

O relacionamento com os colegas da escola e da vizinhança é bom, sendo que o avô afirma que L "tem muitas namoradas". Suas atividades preferidas incluem brincar, computador e conversar.

Procuram suporte na Associação Paulista de Mucopolissacaridoses.

O avô não relata alterações no desenvolvimento de L, excetuando-se as físicas.

A avó recebeu diagnóstico de CA mama há cerca de três meses, sobrecarregando ainda mais a família.

Atualmente, faz reposição enzimática no Hemocentro de Ribeirão Preto.

\section{Diagnóstico Multiaxial:}

Eixo I: sem diagnóstico psiquiátrico atual

Eixo II: Déficit moderado (nível adaptativo geral: 55), compatível com retardo mental moderado

Eixo III: Mucopolissacaridose tipo VI

Eixo IV: Família organizada, dinâmica satisfatória, instável

Eixo V: CGAS: 65 (alguma dificuldade em uma única área)

Comentário clínico: embora a superproteção tenha sido um achado constante nas entrevistas realizadas para este trabalho, este avô sobressaiu-se muito. Não permitia que o neto sequer comesse com as próprias mãos e resolvendo absolutamente tudo para ele. $O$ tratamento 
mais infantilizado do mesmo também chamou-me a atenção. O menino, por sua vez, recusou-se a falar comigo, embora tenha prestado atenção em tudo o que dizíamos, dando mostras de que compreendia, e tenha solicitado o avô algumas vezes (por meio de gestos e murmúrios, mas sem que eu pudesse distinguir suas palavras).

\section{Caso 22:}

KC, 11 anos, sexo feminino.

Mora com o pai e uma babá. Os pais estão separados desde 2005 e o pai está em litígio para obter a guarda definitiva de K, alegando que a mãe a negligenciava, apesar de receber pensão do ex-marido (“ela não está nem aí”). O pai conta que a gravidez de K foi conturbada, tendo ocorrido um quadro de eclâmpsia, com provável sofrimento fetal. Além disso, a menina apresentou episódios convulsivos no período neonatal e, segundo o pai, nunca apresentou um desenvolvimento igual ao das outras crianças.

Frequentou uma escola normal por poucos meses, mas nunca conseguiu acompanhar os colegas. Atualmente, frequenta APAE.

Gosta da companhia de uma prima, com quem joga bola e, às vezes, brinca de pega-pega. Não tem outros amigos e gosta de ver TV e ouvir música.

Iniciou controle noturno de esfíncter vesical apenas aos 10 anos, sendo que o pai diz que ela ficava assustada, triste e envergonhada quando percebia o havia acontecido. Também apresentou atraso no controle de esfíncter anal. Retrai-se muito na presença de estranhos, chorando e gritando ao ser exposta a situações novas. Presenciou o pai ser agredido com uma faca há um ano, mas, aparentemente, isso não lhe causou impacto significativo.

Durante a avaliação, K apresentou pouco contato visual e nenhum contato verbal, inquietação motora e negativismo.

\section{Diagnóstico Multiaxial:}

Eixo I: Autismo Infantil (ATA: 18, CARS: 28,5)

Eixo II: Déficit Grave (nível adaptativo geral: 26), compatível com retardo mental grave 
Eixo III: Mucopolissacaridose tipo VII (S. Sly)

Eixo IV: Família desestruturada, dinâmica insatisfatória, estável

Eixo V: CGAS: 40 (limitação importante no funcionamento em várias áreas)

Comentário clínico: este pai parecia ansioso em falar, especialmente sobre os maus cuidados da mãe para com a menina e o litígio para obter a guarda da mesma. Curiosamente, ele foi um dos que menos apresentou o traço de superproteção, tão comum nas outras famílias, aparentemente conseguindo prover um ambiente adequado para o desenvolvimento de $K$, dentro de seu potencial individual.

\subsection{Características Sociodemográficas}

A amostra avaliada foi composta por 22 indivíduos, sendo 13 do sexo masculino e 9 do sexo feminino.

\section{Distribuição da amostra segundo sexo e tipo de MPS}

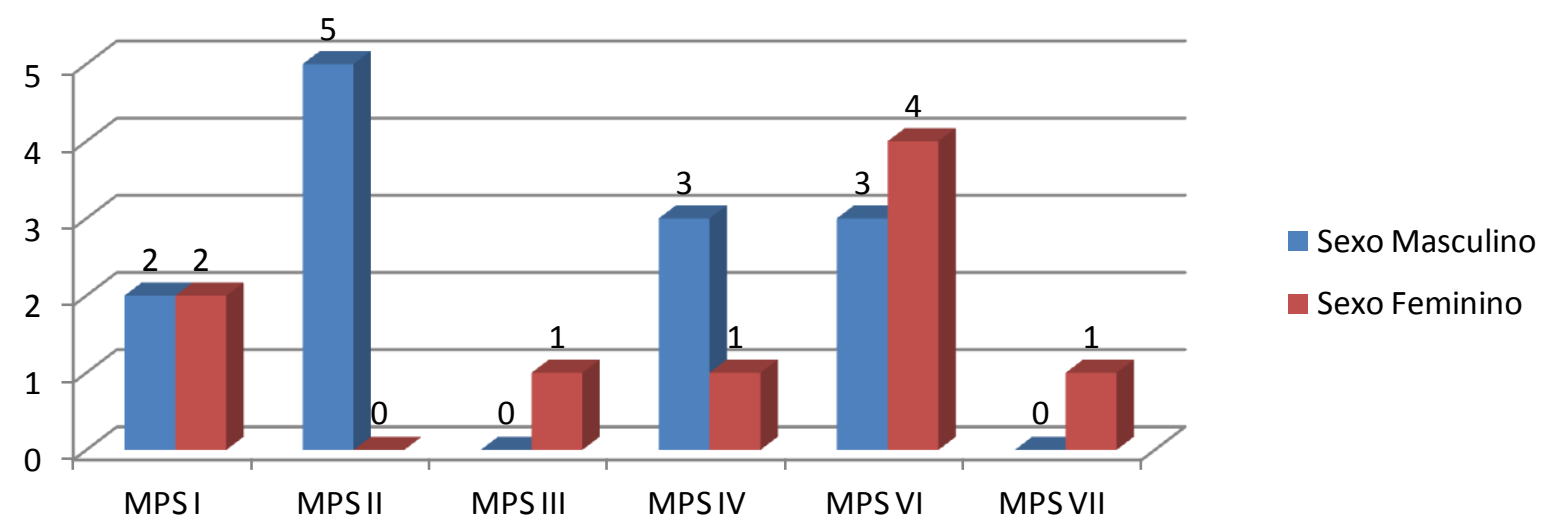

Gráfico 1: Observar existência apenas do sexo masculino em função da herança ligada ao X na MPS II. 
No que se refere à faixa etária, observamos um predomínio de indivíduos nas faixas etárias escolar (10 indivíduos) e da adolescência (9 indivíduos). A faixa etária pré-escolar contou apenas com 3 indivíduos.

\section{Distribuição da amostra por faixa etária}

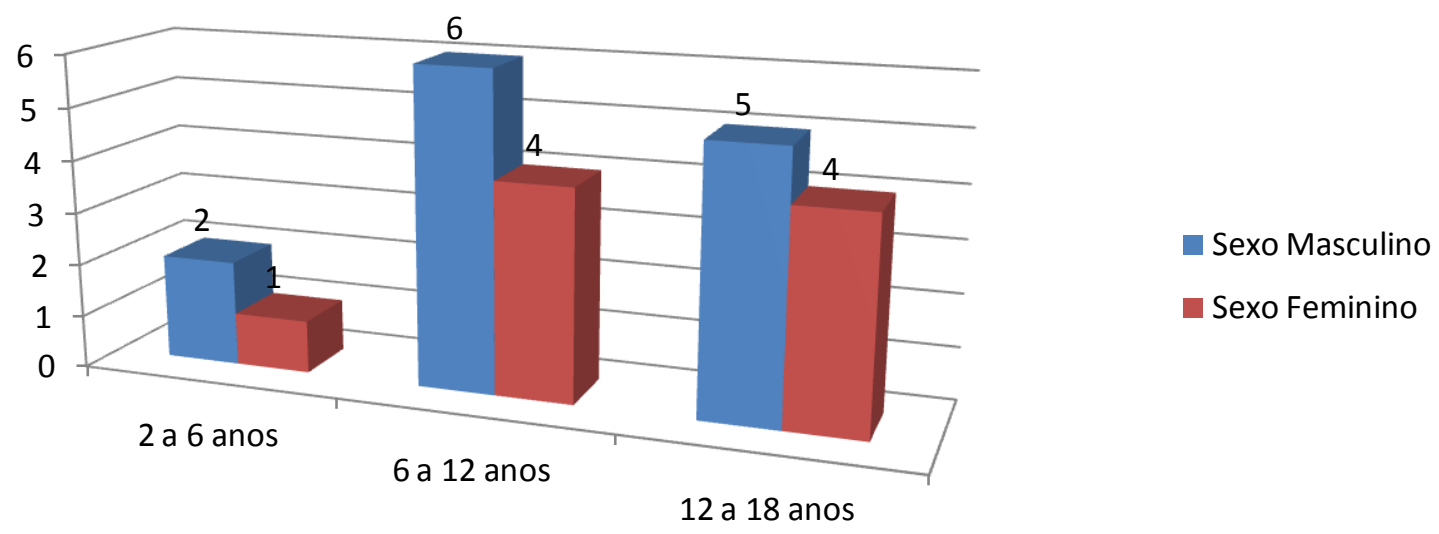

Gráfico 2: Observar a pequena representatividade de crianças maiores e a maior presença a partir da idade escolar, possivelmente devido a demora diagnóstica.

A freqüência escolar mostrou-se insatisfatória, com grande parte dos indivíduos fora da mesma $(n=8)$. Esta discrepância em relação à população geral foi estatisticamente significativa após análise através de teste $\mathrm{G}(\mathrm{p}=0,0075)$.

\section{Frequência Escolar}

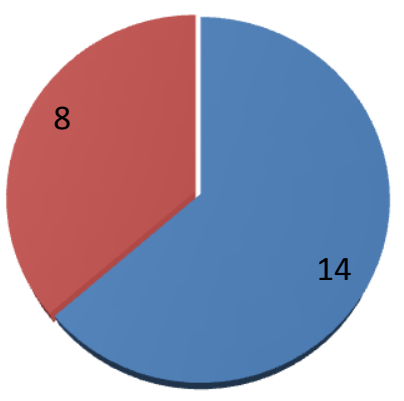

- Sim

não

Gráfico 3: Observar a grande evasão escolar, mesmo com a existência de legislação que prevê a inclusão escolar de todas as crianças. 
A composição familiar mostrou-se variável, sendo que 14 famílias eram compostas por ambos os pais e seus filhos; 6 famílias eram compostas por apenas um dos genitores e os filhos; uma família era composta pela mãe, o padrasto e os filhos; e uma criança vive com os avós.

\section{Composição Familiar}

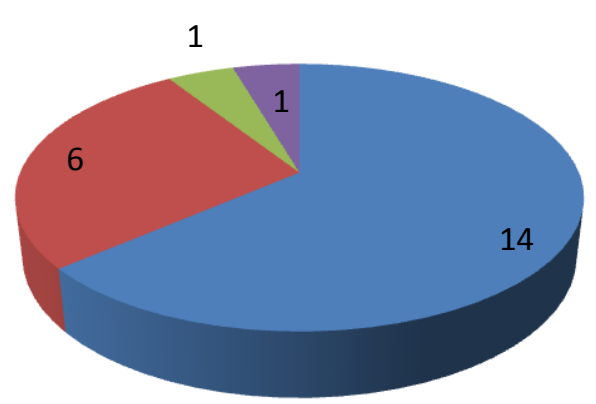

Ambos os pais

- Monoparental

- Reconstituída

- Avós

Gráfico 4: Notar a grande parcela de pacientes que não vivem com ambos os pais.

\subsection{Perfil Psiquiátrico}

Os resultados mostram que, dos vinte e dois indivíduos avaliados, dez apresentaram ao menos um transtorno mental no momento da avaliação (casos 1, 2, 3, 4, 8, 10, 16, 17, 19 e 22) e cinco já os haviam apresentado anteriormente em suas vidas (casos 11, 12, 14, 16 e 22). Assim, 15 indivíduos apresentaram algum transtorno mental em algum momento de suas vidas, sendo que esta maior prevalência em relação à população geral mostrou-se estatisticamente significativa após análise com teste binomial $(\mathrm{p}<0,0001)$. É importante ressaltar que dois indivíduos apresentaram transtornos mentais passados e atuais (casos 16 e 22). A ocorrência de comorbidade entre dois ou mais transtornos também foi observada, acontecendo em seis indivíduos (casos 1, 2, 4, 8, 10 e 19).

Os transtornos mentais atuais mais frequentemente detectados foram os relacionados ao controle esfincteriano. Sete indivíduos apresentaram quadros de enurese, sendo 
três casos de enurese primária (caso 4, noturna e diurna; casos 3 e 17, apenas noturna) e quatro de enurese secundária (casos 1, 8 e 10, noturna e diurna; caso 19, apenas noturna). No caso da encoprese, houve quatro casos, sendo um de encoprese primária (caso 4) e três de encoprese secundária (casos 2, 8 e 10). Quatro crianças foram diagnosticadas como tendo autismo infantil. Além desses, houve um caso de cada um dos seguintes transtornos: transtorno depressivo maior (subtipo melancólico), transtorno de ajustamento com humor depressivo, transtorno mental devido a condição médica geral (neste caso, um quadro de hidrocefalia seguido por complicações pós operatórias), fobia social e transtorno opositivo desafiador.

Em relação aos transtornos mentais passados, observaram-se dois casos de enurese (casos 12 e 22), dois casos de transtorno de estresse pós-traumático (casos 11 e 12), dois casos de transtorno de ansiedade de separação (casos 11 e 22), um caso de transtorno de ajustamento com humor depressivo (caso 16), um caso de transtorno de ansiedade generalizada (caso 14) e um caso de encoprese (caso 22).

As comorbidades distribuíram-se da seguinte forma: o paciente 1 apresentou transtorno depressivo maior, enurese secundária e encoprese secundária; o paciente 2 apresentou autismo infantil, transtorno de ajustamento com humor depressivo e encoprese secundária; o paciente número 4 apresentou transtorno mental orgânico, enurese primária e encoprese primária; o paciente número 8 apresentou autismo infantil, enurese secundária e encoprese secundária, bem como o paciente 10; e o paciente 19 apresentou enurese noturna secundária e transtorno opositivo desafiador.

O detalhamento destes dados pode ser melhor visualizado nas tabelas e nos gráficos que seguem: 
Tabela 3: Perfil psiquiátrico da amostra estudada, segundo avaliação clínica e resultados da K-SADS

\begin{tabular}{|c|c|c|c|c|}
\hline & Idade & MPS & KSADS atual & KSADS passado \\
\hline 1 & $13 \mathrm{a}$ & I & $\begin{array}{l}\text { T. Depressivo Maior, subtipo } \\
\text { melancólico } \\
\text { Enurese (secundária) } \\
\text { Encoprese (secundária) }\end{array}$ & - \\
\hline 2 & $13 \mathrm{a}$ & $\mathrm{I}$ & $\begin{array}{l}\text { Encoprese (secundária) } \\
\text { T. Ajustamento com Humor Depressivo }\end{array}$ & - \\
\hline 3 & $8 \mathrm{a}$ & I & Enurese noturna (primária) & - \\
\hline 4 & $7 \mathrm{a}$ & I & $\begin{array}{l}\text { T. Mental devido a Condição Médica } \\
\text { Geral } \\
\text { Enurese (primária) } \\
\text { Encoprese (primária) }\end{array}$ & - \\
\hline 5 & $16 \mathrm{a}$ & II & - & - \\
\hline 6 & $9 \mathrm{a}$ & II & - & - \\
\hline 7 & $7 \mathrm{a}$ & II & - & - \\
\hline 8 & $9 \mathrm{a}$ & II & $\begin{array}{l}\text { Enurese (secundária) } \\
\text { Encoprese (secundária) }\end{array}$ & - \\
\hline 9 & $3 a$ & II & - & - \\
\hline 10 & $13 \mathrm{a}$ & III & $\begin{array}{l}\text { Enurese (secundária) } \\
\text { Encoprese (secundária) }\end{array}$ & - \\
\hline 11 & $17 \mathrm{a}$ & IV & - & $\begin{array}{l}\text { T. estresse Pós Traumático } \\
\text { T. Ansiedade de Separação }\end{array}$ \\
\hline 12 & $12 \mathrm{a}$ & IV & - & $\begin{array}{l}\text { Enurese (primária) } \\
\text { T. Estresse Pós Traumático }\end{array}$ \\
\hline 13 & $15 \mathrm{a}$ & IV & - & - \\
\hline 14 & $15 \mathrm{a}$ & IV & - & T. Ansiedade Generalizada \\
\hline 15 & $2 \mathrm{a}$ & VI & Menor de 6 anos & - \\
\hline 16 & $10 \mathrm{a}$ & VI & Fobia social & T. Ajustamento com Humor Depressivo \\
\hline 17 & $7 \mathrm{a}$ & VI & Enurese noturna (primária) & - \\
\hline 18 & $16 \mathrm{a}$ & VI & - & - \\
\hline 19 & $5 \mathrm{a}$ & VI & $\begin{array}{l}\text { Enurese noturna (secundária) } \\
\text { T. Opositivo Desafiador }\end{array}$ & - \\
\hline 20 & $11 \mathrm{a}$ & VI & - & - \\
\hline 21 & $7 \mathrm{a}$ & VI & - & - \\
\hline 22 & $11 \mathrm{a}$ & VII & - & $\begin{array}{l}\text { Enurese (primária), Encoprese (primária) } \\
\text { T. Ansiedade de Separação }\end{array}$ \\
\hline
\end{tabular}


Tabela 4: Perfil psiquiátrico da amostra estudada, segundo avaliação clínica e instrumentos ATA e CARS

\begin{tabular}{lllll}
\hline & Idade & MPS & ATA & CARS \\
\hline $\mathbf{1}$ & $13 \mathrm{a}$ & I & 5 & 20 \\
$\mathbf{2}$ & $13 \mathrm{a}$ & I & 12 & 35 (Autismo Infantil) \\
$\mathbf{3}$ & $8 \mathrm{a}$ & I & 6 & 18,5 \\
$\mathbf{4}$ & $7 \mathrm{a}$ & I & 10 & 26,5 \\
$\mathbf{5}$ & $16 \mathrm{a}$ & II & 0 & 18,5 \\
$\mathbf{6}$ & $9 \mathrm{a}$ & II & 0 & 15 \\
$\mathbf{7}$ & $7 \mathrm{a}$ & II & 3 & 16,5 \\
$\mathbf{8}$ & $9 \mathrm{a}$ & II & 24 (Autismo Infantil) & 35,5 (Autismo Infantil) \\
$\mathbf{9}$ & $3 \mathrm{a}$ & II & 11 & 20,5 \\
$\mathbf{1 0}$ & $13 \mathrm{a}$ & III & 14 & 31,5 (Autismo Infantil) \\
$\mathbf{1 1}$ & $17 \mathrm{a}$ & IV & 16 & 0 \\
$\mathbf{1 2}$ & $12 \mathrm{a}$ & IV & 2 & 17 \\
$\mathbf{1 3}$ & $15 \mathrm{a}$ & IV & 2 & 17 \\
$\mathbf{1 4}$ & $15 \mathrm{a}$ & IV & 0 & 16 \\
$\mathbf{1 5}$ & $2 \mathrm{a}$ & VI & 0 & 15 \\
$\mathbf{1 6}$ & $10 \mathrm{a}$ & VI & 1 & 17 \\
$\mathbf{1 7}$ & $7 \mathrm{a}$ & VI & 9 & 20 \\
$\mathbf{1 8}$ & $16 \mathrm{a}$ & VI & 3 & 19 \\
$\mathbf{1 9}$ & $5 \mathrm{a}$ & VI & 5 & 19,5 \\
$\mathbf{2 0}$ & $11 \mathrm{a}$ & VI & 1 & 16 \\
$\mathbf{2 1}$ & $7 \mathrm{a}$ & VI & 2 & 19 \\
$\mathbf{2 2}$ & $11 \mathrm{a}$ & VII & 18 (Autismo Infantil) \\
\hline
\end{tabular}




\section{Transtorno Mental Observado versus Esperado}

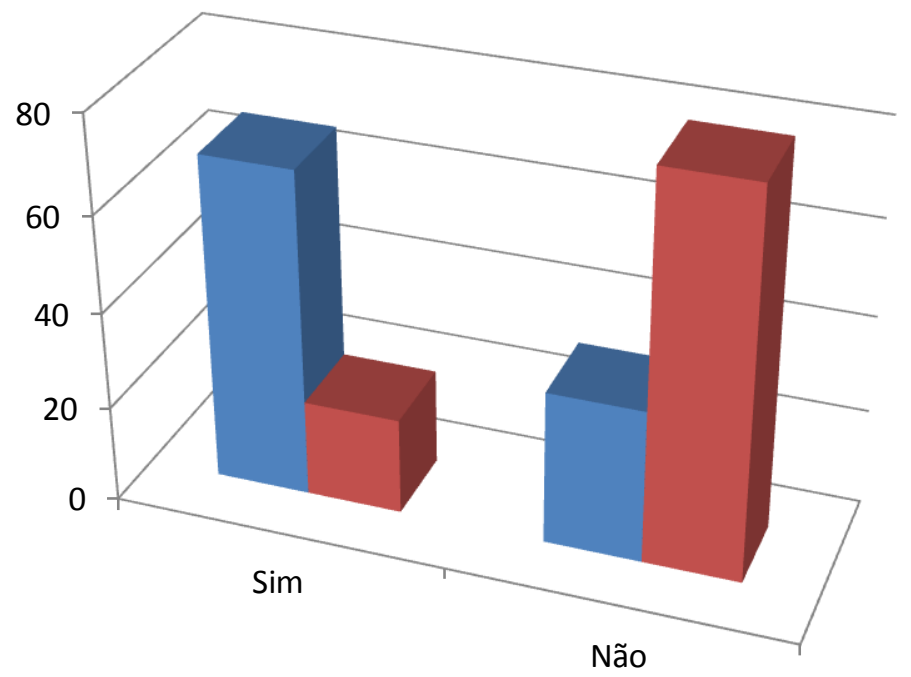

Frequência na amostra

Frequência na população

Gráfico 5: A maior ocorrência de transtornos mentais na amostra estudada em relação à população geral foi estatisticamente significativa $(\mathbf{p}<0,05)$.

\section{Transtorno Mental Atual}

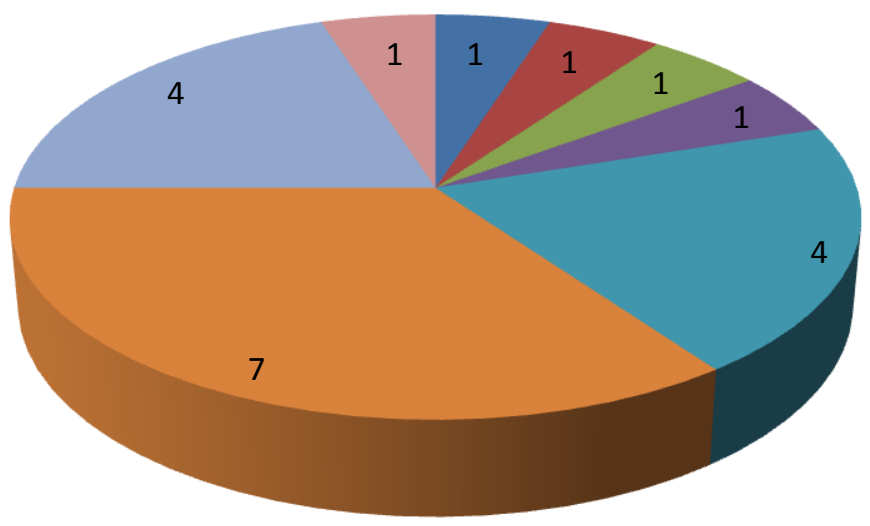

- Transtorno Depressivo Maior

- Transtorno de Ajustamento

Fobia Social

- Transtorno Opositivo Desafiador

Autismo Infantil

Enurese

Encoprese

- Transtorno Mental devido a Condição Médica Geral

Gráfico 6: A alta prevalência de enurese e encoprese pode estar ligada a alterações medulares próprias das mucopolissacaridoses e representar uma sobreposição de diagnósticos clínicos e psiquiátricos. 


\section{Transtorno Mental Passado}

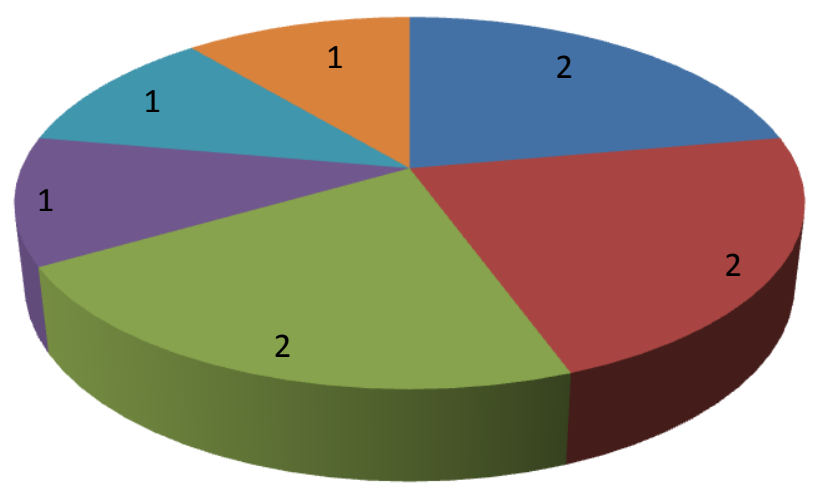

Transtorno de Estresse Pós Traumático

Transtorno de Ansiedade de Separação

Enurese

Encoprese

Transtorno de Ansiedade Generalizada

Gráfico 7: A alta prevalência de enurese e encoprese pode estar ligada a alterações medulares próprias das mucopolissacaridoses e representar uma sobreposição de diagnósticos clínicos e psiquiátricos.

\subsection{Comportamento Adaptativo}

Avaliando os tipos de MPS de maneira geral, vemos que o desempenho médio de todos eles encontra-se em um nível deficitário. Assim, as MPS IV e VI possuem desempenho limítrofe; a MPS II possui desempenho compatível com déficit leve; a MPS I, com déficit moderado; a MPS VII, com déficit grave e a MPS III, com déficit profundo. Cabe aqui, a ressalva de que, especialmente nos casos de MPS III e VII, onde foi avaliada apenas uma criança de cada, a generalização dos dados deve ser feita com extrema cautela.

Detalhando os domínios avaliados, observa-se que, na MPS I, o domínio das atividades de vida diária (AVD) tende a ser o mais prejudicado, seguido pelos domínios motor, comunicacional e de socialização, nesta ordem. Individualmente, houve diferença estatisticamente significativa que indicou que o prejuízo comunicacional mais acentuado não deveu-se ao acaso em dois indivíduos e o social, em um indivíduo. ${ }^{6}$

Na MPS II, os domínios comunicacional e de AVD apresentam resultados semelhantes, sendo inferiores ao domínio de socialização e superiores ao domínio motor. Neste

\footnotetext{
${ }^{6}$ Esta diferença é fornecida pelo próprio instrumento utilizado, a partir da análise dos dados de 3000 crianças avaliadas para sua elaboração, e indica associações pouco usuais entre desempenhos nos diferentes domínios.
} 
caso, a diferença mostrou-se estatisticamente significativa para um pior desempenho comunicacional em um caso, um melhor desempenho social em um caso e um melhor desempenho de AVD em um caso.

A paciente com MPS III apresentou desempenho compatível com déficit profundo em todos os domínios avaliados.

Na MPS IV, observamos uma discrepância entre o desempenho no domínio das AVD, muito inferior ao dos outros domínios, sendo que os domínios comunicacional e de socialização apresentam desempenho semelhante e o domínio motor situa-se numa faixa de desempenho intermediária. Essa diferença foi estatisticamente significativa em dois indivíduos. Outras diferenças estatisticamente significativas foram o domínio comunicacional melhor do que a média em um indivíduo e o domínio de socialização melhor que a média em dois indivíduos.

Na MPS VI, vemos prejuízos maiores nas áreas de AVD e motora, nitidamente inferiores às áreas comunicacional e de socialização. Esse melhor desempenho comunicacional e pior desempenho em AVD foi estatisticamente significativo em três indivíduos. O melhor desempenho de socialização foi estatisticamente significativo em dois indivíduos e o pior desempenho motor foi estatisticamente significativo em um indivíduo. Um pior desempenho isolado em AVD foi observado em um indivíduo.

Por fim, na paciente com MPS VII, observamos piores desempenhos dos domínios comunicacional e de AVD, sendo que a diferença foi estatisticamente significativa para o domínio comunicacional.

Os gráficos e a tabela que seguem ilustram estes achados: 


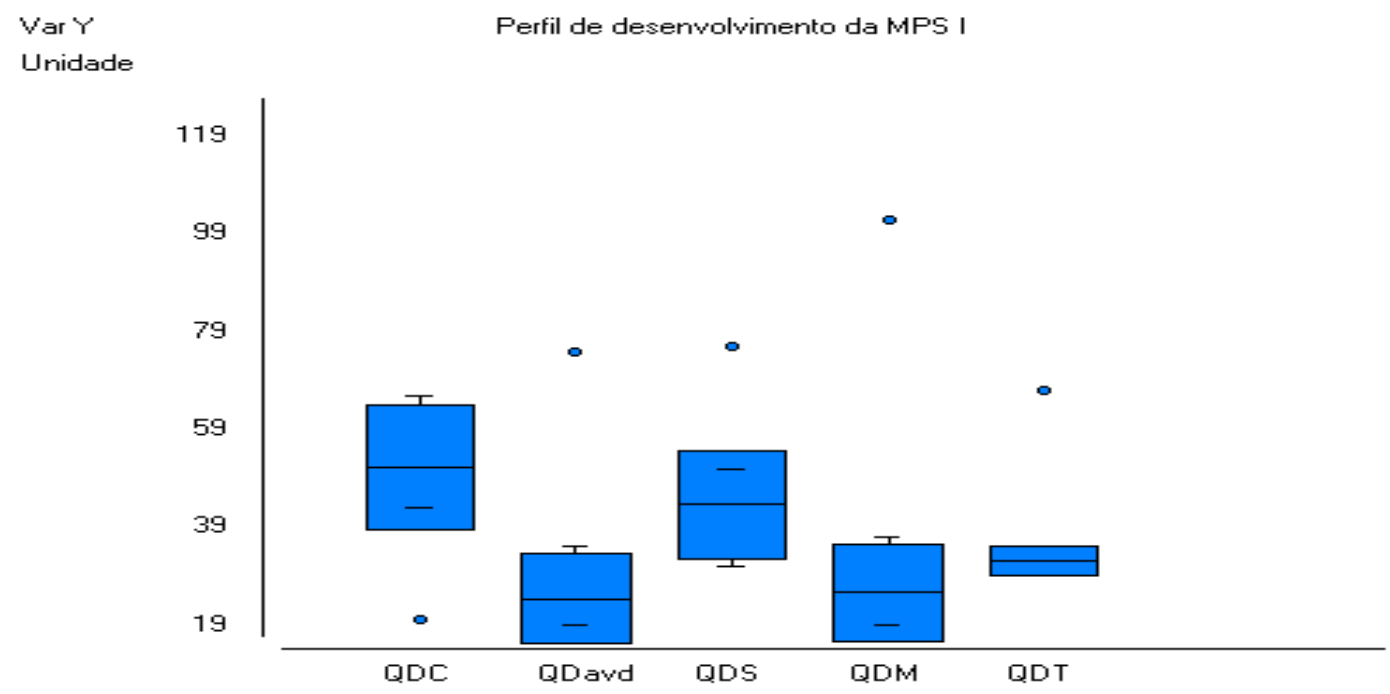

Gráfico 8: Perfil de desenvolvimento da MPS I, mostrando maior prejuízo nos quoeficientes de AVD e motor, com grande discrepância em relação a comunicação e sociabilidade. QDT: quoeficiente de desenvolvimento total; QDC: quoeficiente de desenvolvimento comunicacional; QDavd: quoeficiente de desenvolvimento de atividades de vida diária; QDS: quoeficiente de desenvolvimento de socialização; QDM: quoeficiente de desenvolvimento motor.

$\operatorname{Var} Y$

Unidade

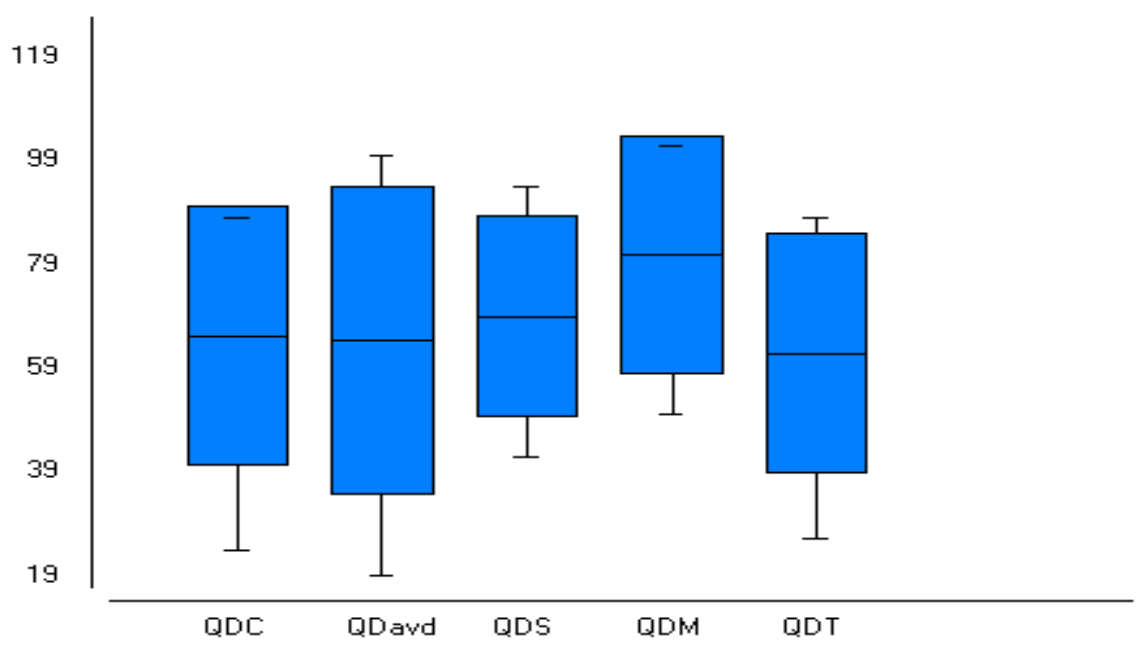

Gráfico 9: Perfil de desenvolvimento da MPS II, evidenciando homogeneidade entre os diferentes domínios avaliados. QDT: quoeficiente de desenvolvimento total; QDC: quoeficiente de desenvolvimento comunicacional; QDavd: quoeficiente de desenvolvimento de atividades de vida diária; QDS: quoeficiente de desenvolvimento de socialização; QDM: quoeficiente de desenvolvimento motor. 


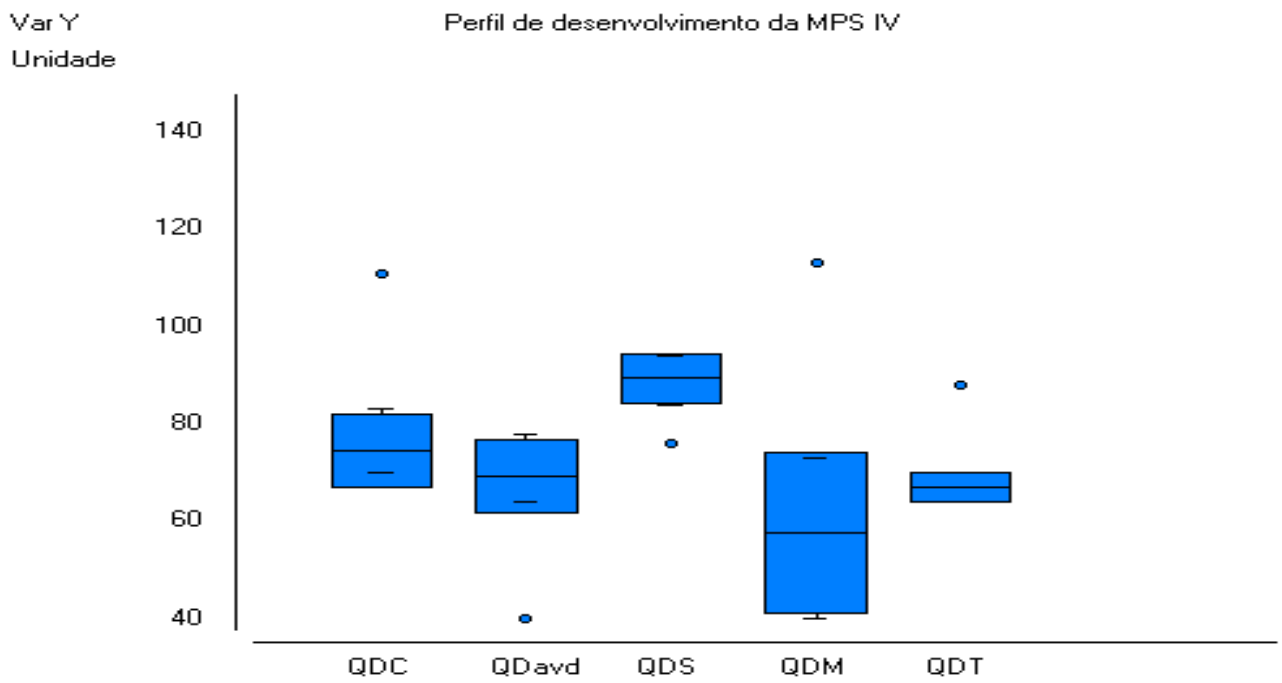

Gráfico 10: Perfil de desenvolvimento da MPS IV, mostrando menor prejuízo no domínio de socialização. QDT: quoeficiente de desenvolvimento total; QDC: quoeficiente de desenvolvimento comunicacional; QDavd: quoeficiente de desenvolvimento de atividades de vida diária; QDS: quoeficiente de desenvolvimento de socialização; QDM: quoeficiente de desenvolvimento motor.

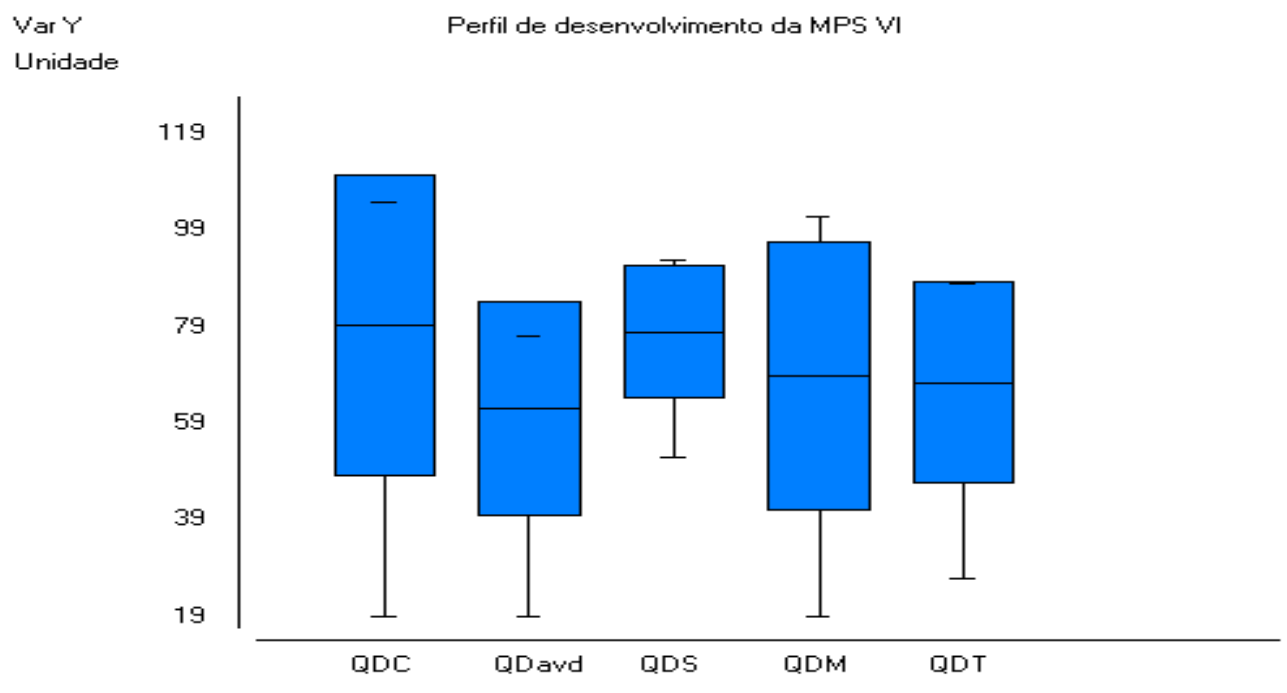

Gráfico 11: Perfil de desenvolvimento da MPS VI, mostrando homogeneidade entre os domínios avaliados. QDT: quoeficiente de desenvolvimento total; QDC: quoeficiente de desenvolvimento comunicacional; QDavd: quoeficiente de desenvolvimento de atividades de vida diária; QDS: quoeficiente de desenvolvimento de socialização; QDM: quoeficiente de desenvolvimento motor. 


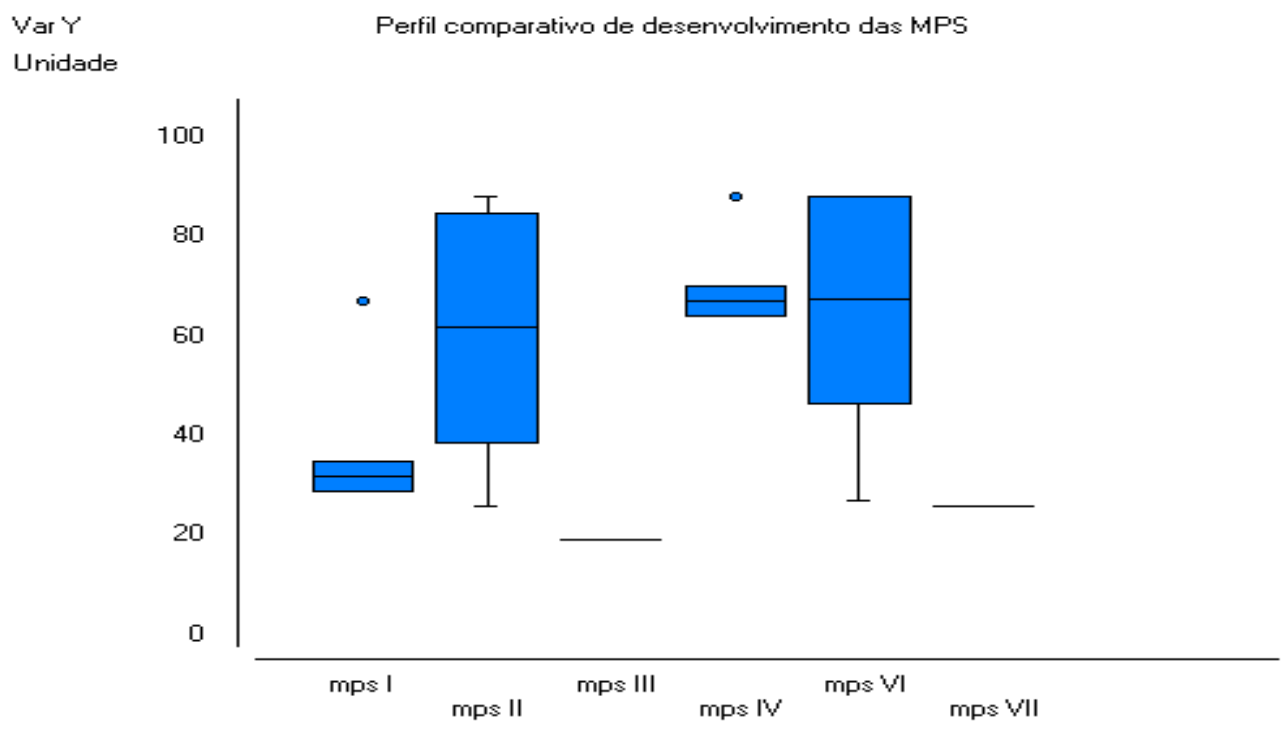

Gráfico 12: Perfil comparativo de desenvolvimento das MPS; notar que, embora os quoeficientes totais sejam equivalentes entre as MPS II e VI, seus perfis são divergentes entre si. 
Tabela 5: Comportamento adaptativo da amostra estudada, segundo resultados das Escalas de Comportamento Adaptativo de Vineland

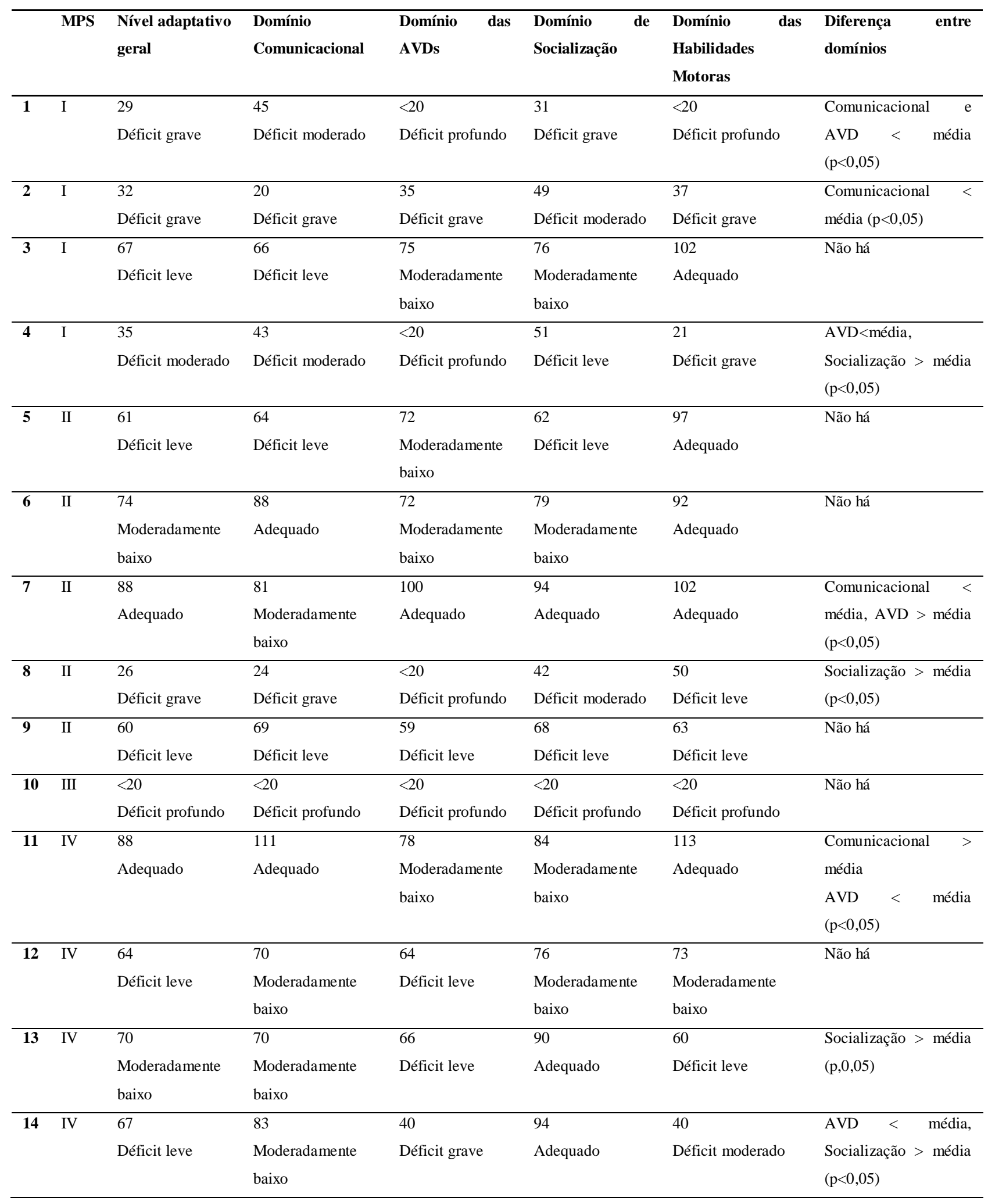




\begin{tabular}{|c|c|c|c|c|c|c|c|}
\hline & MPS & $\begin{array}{l}\text { Nível adaptativo } \\
\text { geral }\end{array}$ & $\begin{array}{l}\text { Domínio } \\
\text { Comunicacional }\end{array}$ & $\begin{array}{l}\text { Domínio das } \\
\text { AVDs }\end{array}$ & $\begin{array}{ll}\text { Domínio } & \text { de } \\
\text { Socialização } & \end{array}$ & $\begin{array}{l}\text { Domínio das } \\
\text { Habilidades } \\
\text { Motoras }\end{array}$ & $\begin{array}{l}\text { Diferença entre } \\
\text { domínios }\end{array}$ \\
\hline \multirow[t]{2}{*}{15} & VI & 81 & 105 & 71 & 83 & 86 & Comunicacional \\
\hline & & $\begin{array}{l}\text { Moderadamente } \\
\text { baixo }\end{array}$ & Adequado & $\begin{array}{l}\text { Moderadamente } \\
\text { baixo }\end{array}$ & $\begin{array}{l}\text { Moderadamente } \\
\text { baixo }\end{array}$ & Adequado & $\begin{array}{l}\text { média, AVD < média } \\
(\mathrm{p}<0,05)\end{array}$ \\
\hline \multirow[t]{2}{*}{16} & VI & 88 & 105 & 76 & 93 & 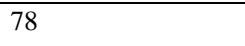 & Comunicacional > \\
\hline & & Adequado & Adequado & $\begin{array}{l}\text { Moderadamente } \\
\text { baixo }\end{array}$ & Adequado & $\begin{array}{l}\text { Moderadamente } \\
\text { baixo }\end{array}$ & $\begin{array}{l}\text { média, AVD < média } \\
(\mathrm{p}<0,05)\end{array}$ \\
\hline 17 & VI & 79 & 99 & 72 & 82 & 87 & Comunicacional > \\
\hline 18 & VI & $\begin{array}{l}27 \\
\text { Déficit grave }\end{array}$ & $\begin{array}{l}<20 \\
\text { Déficit profundo }\end{array}$ & $\begin{array}{l}<20 \\
\text { Déficit profundo }\end{array}$ & $\begin{array}{l}52 \\
\text { Déficit moderado }\end{array}$ & $\begin{array}{l}<20 \\
\text { Déficit profundo }\end{array}$ & $\begin{array}{l}\text { Socialização > média } \\
(p<0,05)\end{array}$ \\
\hline 19 & VI & $\begin{array}{l}66 \\
\text { Déficit leve }\end{array}$ & $\begin{array}{l}69 \\
\text { Déficit leve }\end{array}$ & $\begin{array}{l}77 \\
\text { Moderadamente } \\
\text { baixo }\end{array}$ & $\begin{array}{l}88 \\
\text { Adequado }\end{array}$ & $\begin{array}{l}55 \\
\text { Déficit moderado }\end{array}$ & $\begin{array}{l}\text { Socialização > média, } \\
\text { motor } \\
(\mathrm{p}<0,05)\end{array}$ \\
\hline 20 & VI & $\begin{array}{l}76 \\
\text { Moderadamente } \\
\text { baixo }\end{array}$ & $\begin{array}{l}92 \\
\text { Adequado }\end{array}$ & $\begin{array}{l}75 \\
\text { Moderadamente } \\
\text { baixo }\end{array}$ & $\begin{array}{l}79 \\
\text { Moderadamente } \\
\text { baixo }\end{array}$ & $\begin{array}{l}102 \\
\text { Adequado }\end{array}$ & - \\
\hline 21 & VI & $\begin{array}{l}55 \\
\text { Déficit leve }\end{array}$ & $\begin{array}{l}66 \\
\text { Déficit leve }\end{array}$ & $\begin{array}{l}44 \\
\text { Déficit } \\
\text { moderado }\end{array}$ & $\begin{array}{l}69 \\
\text { Déficit leve }\end{array}$ & $\begin{array}{l}55 \\
\text { Déficit leve }\end{array}$ & AVD $<$ média $(p<0,05)$ \\
\hline 22 & VII & $\begin{array}{l}26 \\
\text { Déficit grave }\end{array}$ & $\begin{array}{l}20 \\
\text { Déficit grave }\end{array}$ & $\begin{array}{l}<20 \\
\text { Déficit profundo }\end{array}$ & $\begin{array}{l}48 \\
\text { Déficit moderado }\end{array}$ & $\begin{array}{l}45 \\
\text { Déficit moderado }\end{array}$ & $\begin{array}{l}\text { Comunicacional } \\
\text { média }(\mathrm{p}<0,05)\end{array}$ \\
\hline
\end{tabular}

Legenda: a diferença entre domínios revela diferença estatisticamente significativa entre duas áreas de habilidades de uma mesma criança, evidenciando áreas de melhor e pior desempenho não devidas ao acaso.

Além do exposto, podemos tentar correlacionar a presença ou ausência de transtorno mental ao nível adaptativo de cada indivíduo. Assim, entre os indivíduos com nível adaptativo dentro da normalidade $(n=3)$, encontramos um afetado (33,3\%); entre os com nível adaptativo limítrofe $(n=5)$, também encontramos um afetado (20\%); entre os com déficit leve $(n=7)$, dois afetados (29\%); o único indivíduo com déficit moderado apresentou ocorrência de transtorno mental (100\%); entre os com déficit grave $(n=5)$, vemos 4 indivíduos acometidos por algum transtorno mental (80\%); e, por fim, a única criança com nível adaptativo compatível déficit profundo, também foi acometida por transtorno mental (100\%). Dessa forma, observamos uma associação entre maior comprometimento adaptativo e maior prevalência de transtornos 
mentais, confirmada após realização do teste de correlação linear de Pearson (índice de correlação $=0,7897, \mathrm{p}<0,0001)$.

O gráfico que segue ilustra tais achados.

\section{Transtorno Mental segundo o Nível Adaptativo}

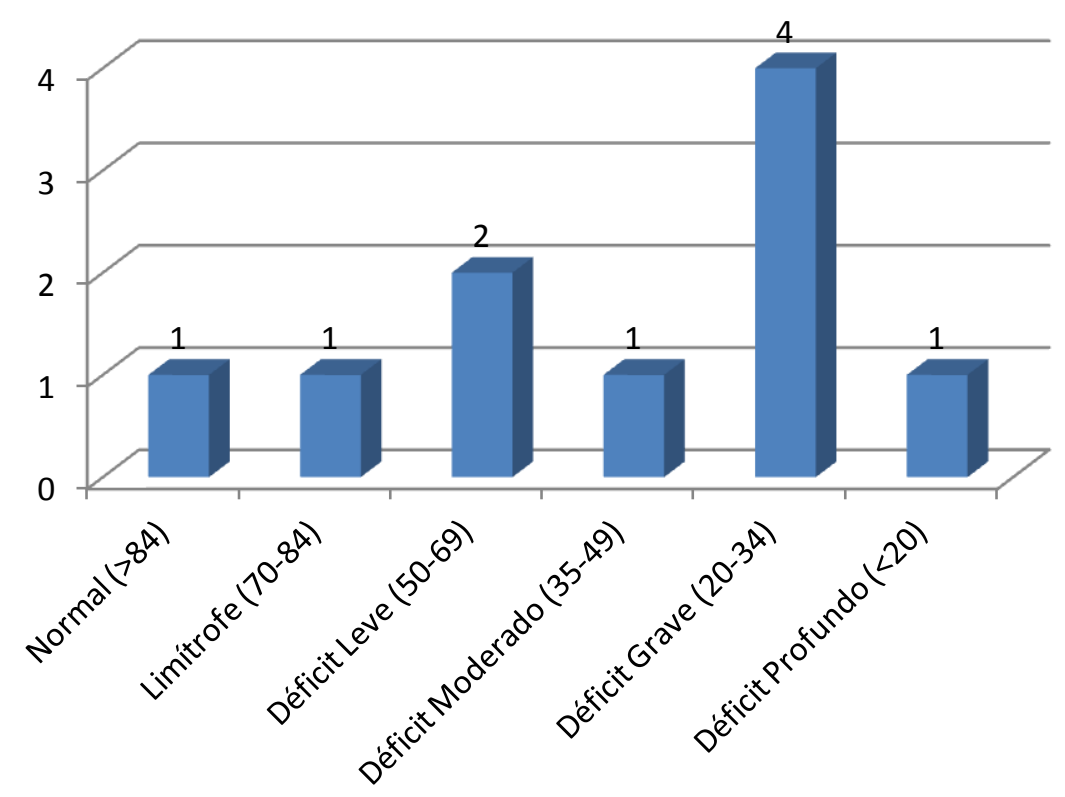

- Casos de Transtorno Mental

Gráfico 13: Observar a tendência de maior co-ocorrência de transtornos mentais e prejuízos no comportamento adaptativo.

\subsection{Funcionamento Global}

A avaliação de funcionamento global demonstrou variar segundo o tipo de MPS. Assim, a MPS I apresentou um score médio da CGAS de 42,5, compatível com um grau moderado de interferência no funcionamento; a MPS II teve score médio de 58,1, correspondendo a funcionamento variável com dificuldades esporádicas; a MPS III obteve score de 10, indicando necessidade de supervisão constante; o score médio da MPS IV foi de 75, 
compatível com não mais que uma limitação leve no funcionamento; a MPS VI teve score médio 62,9, indicando alguma dificuldade em uma única área; e, finalmente, a MPS VII obteve score 40, com limitação importante no funcionamento em várias áreas. Cabe lembrarmos, aqui, que nos casos das MPS III e VII, tivemos oportunidade de avaliar apenas uma criança com cada síndrome. O gráfico seguinte ilustra esses dados:

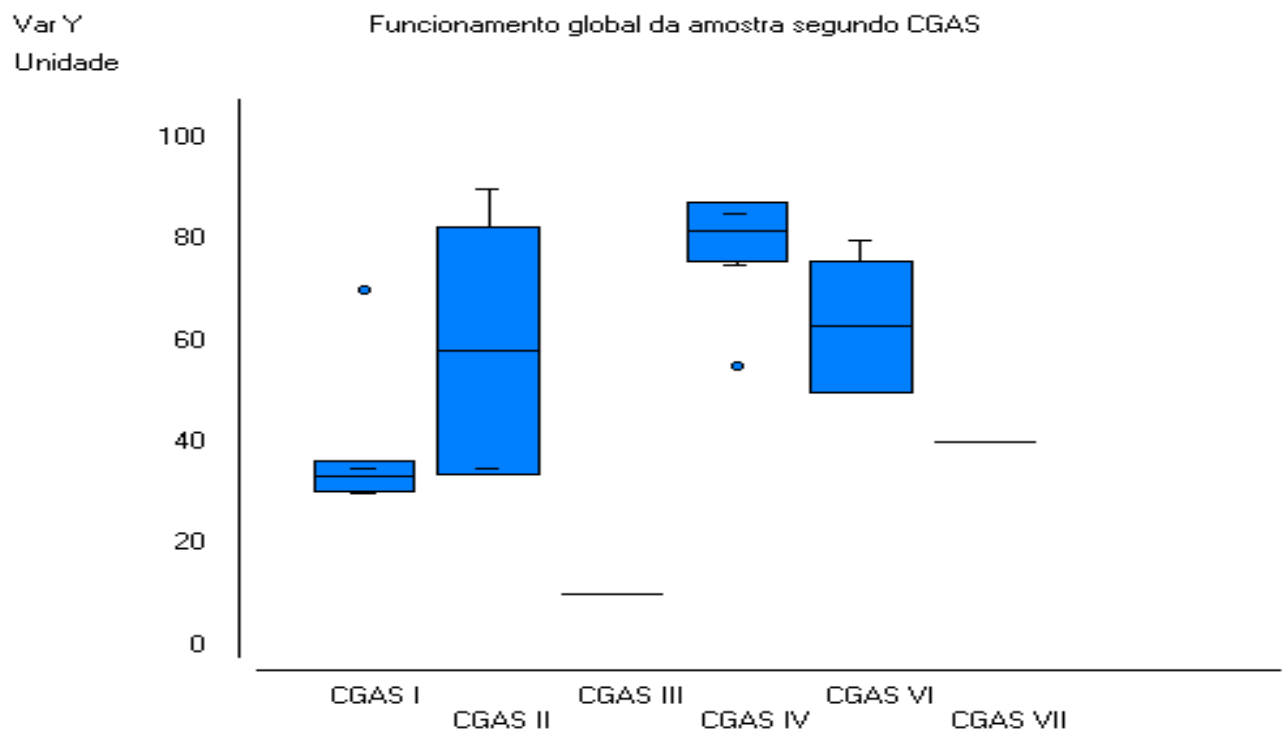

Gráfico 14: Observar a sobreposição entre as MPS II e IV. As MPS III e VII aparecem como traços por serem representadas por apenas um caso cada uma. 


\section{Discussão}

\subsection{Características sociodemográficas}

$\mathrm{Na}$ amostra estudada, composta por 22 pacientes, observou-se uma maior ocorrência de casos de MPS VI (7 casos), seguida pelas MPS II (5 casos), MPS I e IV (4 casos cada). As MPS III e VII foram representadas por apenas um caso cada. Comparando-se estas freqüências com os casos conhecidos no Brasil (Vieira, et al., 2008), temos que elas representam as seguintes parcelas de pacientes com cada diagnóstico: 6\% dos casos de MPS I (total conhecido, 60 casos); $6 \%$ dos casos de MPS II (total conhecido, 82 casos); 3\% dos casos de MPS III (total conhecido, 31 casos); 27\% dos casos de MPS IV (total conhecido, 15 casos); 12\% dos casos de MPS VI (total conhecido, 57 casos); e 25\% dos casos de MPS VII (total conhecido, 4 casos). Assim, embora em números absolutos esta seja considerada uma amostra pequena, devido à raridade da condição em estudo, ela representa $9 \%$ da população geral de pacientes com MPS no Brasil.

No que se refere à distribuição entre os sexos, a superrepresentação do sexo masculino justifica-se por haver um tipo de MPS (tipo II) que acomete apenas indivíduos deste sexo (gráfico 1).

A distribuição etária mostra concentração maior de indivíduos nas faixas de idade escolar e da adolescência, com poucos indivíduos mais jovens. Isto pode ser explicado pela dificuldade diagnóstica que as MPS ainda encontram em nosso país. Em seu estudo de 2008, Vieira et al. determinaram que a mediana de idade quando foi realizado o diagnóstico de MPS era de 76 meses, transcorrendo um longo intervalo de 58 meses entre o surgimento dos primeiros sintomas e o diagnóstico bioquímico da doença (gráfico 2).

A questão da freqüência escolar é preocupante, uma vez que constatamos que 8 dos 22 pacientes estão fora da escola ( $\mathrm{p}=0,0075$, estatisticamente significativa, considerando que o esperado seria que todas as crianças a partir dos seis anos freqüentassem a escola), que é o principal local de convívio social de uma criança, à exceção do ambiente familiar (gráfico 3). No 
discurso dos cuidadores, fica claro que a escolha pelo abandono escolar se deve, por um lado, às dificuldades "logísticas" de transporte, locomoção e supervisão relacionadas às deficiências físicas dos pacientes e, por outro, ao despreparo das escolas para receberem esses alunos. Isso porque, mesmo em tempos onde "inclusão" seja um termo em voga, a mobilização e articulação necessárias para que ela aconteça de forma satisfatória ainda não ocorreram.

Isto deve-se ao fato de serem crianças que, em sua maioria, têm funcionamento deficitário. Demandam, portanto, de um plano pedagógico individualizado, pautado em avaliação minuciosa das capacidades e deficiências de cada um. Essa avaliação, idealmente, deveria ser feita não apenas pela equipe educacional, mas também através de um trabalho integrado com as equipes de saúde.

Entretanto, nem mesmo uma avaliação cognitiva dessas crianças é feita e a escola, geralmente, nada mais sabe sobre a condição daquele aluno além do nome da doença. O que dizer, então, de classes com número reduzido de alunos, professor auxiliar ou acompanhante terapêutico, material adaptado para deficiência visual e/ou auditiva, currículo adaptado para deficiência intelectual...?

Isso, sem falar na mediação necessária com os colegas, visando sua aceitação e inclusão. A grande maioria das entrevistas revelou que essas crianças são alvo de chacotas e provocações, tendo poucos amigos. Quando os têm, são na maioria de fora da escola ou de faixas etárias mais jovens. Com tal contexto de "pseudoinclusão", não causa muito espanto a decisão de retirar o filho da escola, "já que ele não aprende mesmo".

A grande ocorrência de famílias onde os filhos não vivem com ambos os pais (8 famílias, 36\% do total) também chama a atenção. Segundo o Censo 2010, (Instituto Brasileiro de Geografia e Estatística, 2010), 25\% dos filhos moram com apenas um dos pais ou com outros parentes). Os dados encontrados sugerem que as famílias com um filho portador de MPS encontram-se mais sujeitas à dissolução quando comparadas à população geral (gráfico 4).

Um estudo sobre o funcionamento psicodinâmico de famílias que tinham um portador de Síndrome de Down revelou que todas as 10 famílias analisadas tinham grandes dificuldades de expressão afetiva, o que constituiria um obstáculo para o cumprimento de seu potencial para promover o desenvolvimento saudável de seus membros (Becker, 1991).

Outro estudo (Pimentel, 2006), que avaliou famílias de crianças com Síndrome de Cornelia de Lange e Síndrome de Prader-Willi, levanta a questão de a presença de uma criança 
com uma doença genética e rara na família representar, para esta, um momento de crise, levando a alterações em sua dinâmica. Como reações dos pais são descritos sentimentos intensos de culpabilidade, especialmente na mãe, bem como uma desestabilização devida à agressão ao narcisismo dos pais, já que o filho real é muito diferente daquele idealizado. A reação a essa agressão dependeria, então, da relação existente entre os membros do casal e do nível de desenvolvimento individual de cada um, já que o casamento e a constituição de uma família nem sempre são sinais de maturidade parental (Cicco, Paiva, \& Gomes, 2005) (Winnicott, 1960). Assim, os pais respondem a essa ocorrência com várias combinações de vergonha, culpa, depressão, revolta, prostração e hipervigilância. Nesses casos, as relações interpessoais são muito vulneráveis, observando-se dificuldades de relacionamento, hostilidade, fobia da gravidez, rejeição do filho afetado, negligência no cuidado aos outros filhos, superproteção do filho afetado, auto e heteroacusações, conflitos conjugais, entre outros (Pimentel, 2006).

Estudo de 2010 (Nunes, 2010) sobre as repercussões sobre a vida familiar e dos pais de crianças autistas, constatou que frequentemente a relação conjugal era suplantada pela necessidade de cuidados com o filho. Além disso, os pais apresentavam sentimentos ambivalentes de desamparo e esperança, bem como alterações em sua auto-estima.

No caso específico das MPS, podemos imaginar que diversas peculiaridades da própria doença poderiam facilitar a desestabilização do casal: a aparência das crianças vai se deteriorando e tornando-se cada vez mais grosseira, gerando uma maior dificuldade de aceitação por parte dos pais; o jogo de culpabilização entre os membros do casal, uma vez que há uma certeza de transmissão da doença pelos pais aos filhos; a sobrecarga emocional, de trabalho e de custos gerada pelo seguimento médico, já que essas crianças têm muitas complicações clínicas, devendo ser internadas e passar por procedimentos cirúrgicos diversas vezes ao longo de suas vidas; a pequena expectativa de vida de alguns subtipos (pacientes com MPS tipo 1, por exemplo, muitas vezes morrem ao redor dos dez anos de idade), que podem fazer com que se "antecipe" o luto por aquela criança que "irá morrer". 


\subsection{Perfil Psiquiátrico}

A prevalência de transtornos mentais na população estudada é alta, sendo que 15 indivíduos apresentaram algum transtorno mental durante sua vida, o que corresponde a $68 \%$ da amostra ( $\mathrm{p}<0,0001$, estatisticamente significativo). Na população geral, estudo realizado pelo National Institute of Mental Health, dos Estados Unidos da América (EUA) e publicado em 2010, estima que a prevalência de transtorno mental grave ao longo da vida para pessoas com menos de 18 anos de idade seja de cerca de 20\%, com uma prevalência no último ano de cerca de 13\% para crianças com menos de 15 anos (National Institute of Mental Health, 2012). Assim, observa-se que a população de indivíduos com MPS é extremamente vulnerável a transtornos mentais (tabelas 3 e 4, gráficos5, 6 e 7).

A grande ocorrência de transtornos do controle esfincteriano deve ser vista com ressalvas, especialmente os secundários, uma vez que pacientes com MPS podem desenvolver compressão medular ao longo da evolução da doença e esta, por sua vez, pode levar a incontinência urinária. A ocorrência concomitante de um diagnóstico de enurese ou encoprese pela K-SADS e de compressão medular levando a incontinência indica uma possível falha no poder de discriminação do instrumento, uma vez que, semiologicamente, a enurese a encoprese e a incontinência são bastante diferentes. Dessa forma, a incontinência se caracteriza por micção/evacuação incompletas devidas a lesões neurológicas ou viscerais e os diagnósticos de enurese e encoprese correspondem a micção/evacuação completas na ausência de tais lesões (Bernard \& Trouvé, 1977).

A ocorrência de autismo infantil em quatro indivíduos corresponde a uma prevalência de $18 \%$, muito maior que a prevalência na população geral, estimada em 1 caso de transtorno do espectro autístico para cada 110 crianças (National Institute of Mental Health, 2012). Além disso, obtivemos dados discrepantes entre as escalas utilizadas, embora seja descrito que ambas apresentam forte taxa de correlação, com um índice de correlação de Pearson de 0,767 (Cucolicchio, Di Matteo, Paicheco, Gomes, Simone, \& Assumpção Jr, 2010). O ponto de corte utilizado para a ATA (15), mais abrangente que o ponto de 23 apresentado por (Assumpção Jr, et al., 2008) permitiu uma maior sensibilidade de detecção dos quadros de autismo, compatível com a anamnese e a observação clínica (tabela 4). 
Apesar de existirem citações da ocorrência de casos de autismo em pacientes com MPS, localizamos apenas dois relatos de caso em nossa revisão de literatura (Jabourian, Benhamou, \& Bitton, 1996) (Zafeiriou, Ververi, \& Vargiami, 2007). Além disso, em nenhum deles há referência às taxas de associação entre os dois quadros.

Apesar do desempenho adaptativo deficitário (que se correlaciona diretamente ao funcionamento cognitivo e pode ser considerado uma estimativa confiável da ocorrência de retardo mental) e da possibilidade de diversas complicações neurológicas no decurso da doença, encontramos apenas uma criança com transtorno mental orgânico.

Os outros transtornos encontrados correspondem aos transtornos de humor (3 casos), transtornos ansiosos (1 caso) e de comportamento (1 caso), refletindo o perfil de transtornos mais freqüentes na infância e adolescência. Segundo o NIMH (National Institute of Mental Health, 2012), as prevalências de transtornos de humor e transtornos de ansiedade graves ao longo da vida para indivíduos menores de 18 anos é de $14 \%$ e $25 \%$, respectivamente.

No caso dos transtornos mentais passados, os casos de enurese e encoprese correlacionam-se, possivelmente, ao grau de retardo mental apresentado pelos pacientes, uma vez que representaram um atraso na aquisição do controle se comparados à população normal de mesma faixa etária. Os outros transtornos encontrados foram os de humor e de ansiedade, repetindo o resultado encontrado nos transtornos mentais atuais.

Observou-se, também, um índice de comorbidade de 6 casos em 20 pacientes com diagnósticos de transtorno mental atual, ou 30\% da amostra. Esta taxa é menor que a relatada pelo estudo do NIMH, estimada em $40 \%$ dos participantes acometidos por algum transtorno mental (National Institute of Mental Health, 2012).

Não há estudos nacionais detalhados e atualizados sobre a prevalência de transtornos mentais em crianças e adolescentes.

\subsection{Comportamento Adaptativo}

Poucos estudos utilizaram as Escalas de Comportamento Adaptativo de Vineland para avaliar crianças com mucopolissacaridoses. Destes, apenas um traz em seu texto os scores 
dos domínios avaliados para que possamos utilizá-los como parâmetro de comparação. Assim, o presente estudo traz um dado único, por avaliar todos os tipos de MPS sob este ponto de vista (tabela 5, gráficos 8 a 13) permitindo, inclusive, uma comparação entre os perfis de desenvolvimento de cada uma.

Um estudo (Bjoraker, Delaney, Peters, Krivit, \& Shapiro, 2006) a utilizou para avaliar crianças com MPS I em diversos pontos no tempo para dimensionar o impacto de tratamento com transplante de medula óssea. Os scores médios basais, antes do procedimento, mostraram: domínio comunicacional $(88,7)$; domínio das AVD (87,1); domínio de socialização $(94,4)$; domínio motor $(86,5)$. Esses valores são nitidamente mais elevados que os observados em nossa amostra. Possivelmente isso se deve à idade precoce da avaliação, uma vez que a idade média de realização dos transplantes foi de 21,7 meses, bastante inferior à idade média de nossa avaliação (128,8 meses).

Um ponto interessante a ser discutido é a tendência geral de pior desempenho no domínio referente às atividades de vida diária. Embora uma parte desse prejuízo possa ser decorrente das dificuldades motoras, por exemplo, a discrepância observada sugere que haja outros fatores envolvidos nesse resultado. Assim, sugerimos que a superproteção desses indivíduos e a inclinação dos pais e cuidadores para se adiantarem e resolverem todas as tarefas sem estimularem os pacientes a fazê-lo é um fator importante na limitação da autonomia e no pior desempenho adaptativo constatado. Deve-se ressaltar que esses resultados negativos no domínio das AVD contribuem para a piora no score global da escala.

\subsection{Funcionamento Global}

A Children's Global Assessment Scale é um instrumento de avaliação de funcionamento de crianças que pode ser utilizada em diversos contextos. No entanto, para avaliação de crianças com síndromes genéticas e/ou com retardo mental foi pouco utilizada. Não pudemos encontrar nenhum estudo que a tivesse utilizado para avaliar pacientes com mucopolissacaridoses. 
Em nosso estudo, os scores médios de todas as MPS demonstraram funcionamento global prejudicado, com pior desempenho para as MPS III e VII (gráfico 14). Este resultado deve ser visto com cautela, uma vez que houve apenas um representante em cada grupo citado, ambas com hipótese diagnóstica de autismo infantil no eixo I do diagnóstico multiaxial. Em seguida, vemos as MPS I, II, IV e VI, nesta ordem. Estes níveis de funcionamento correspondem grosso modo, ao desempenho adaptativo analisado através das Escalas de Comportamento Adaptativo de Vineland (índice de correlação de Pearson =0,7897, p<0,0001, estatisticamente significativo).

Esta equivalência pode ser considerada esperada, conforme afirma o estudo de (Mathiassen, et al., 2012), que afirma que os níveis de QI global de indivíduos em tratamento para transtornos mentais correlacionam-se diretamente com a melhora dos scores da CGAS após o tratamento. Uma vez que o comportamento adaptativo também está correlacionado aos níveis intelectuais globais, esta é uma correlação que poderia ser esperada também entre as Escalas de Comportamento Adaptativo de Vineland e a CGAS.

\subsection{Impressões Clínicas}

O encontro com essas crianças é marcante. Sua aparência faz pensar que a denominação antiga, gargulismo, não é desprovida de razão. São pequenos, com deformidades esqueléticas, faces grosseiras com olhos infantis. Ao nos aproximarmos, contudo, são apenas crianças. Em sua maioria, bastante tímidos e pueris, dando a impressão de serem bem mais jovens do que o são realmente.

Nenhum deles consentiu em conversar comigo a sós. Assim, as entrevistas foram feitas simultaneamente com criança e cuidador (geralmente a mãe). Durante as mesmas, em sua maioria mostraram-se bastante passivos e tiveram dificuldade em responder ás perguntas. Algumas vezes, porque não as compreendiam. Outras, por puro negativismo. Como exemplo, podemos citar um menino que foi avaliado em sua própria casa e que, enquanto eu conversava com a mãe, prestava atenção e fazia alguns comentários. Quando lhe disse que era a sua vez de responder algumas perguntas, ele saiu da sala para seu quarto e não o vi mais por todo o período em que continuei ali. 
Uma diferença curiosa foi a recepção ao meu contato: os pacientes que estavam recebendo reposição enzimática foram muito mais receptivos à entrevista que os que compareciam apenas a consultas ambulatoriais. Em uma situação, a mãe da menina aceitou conversar comigo apenas enquanto esperava ser chamada para a realização de alguns exames da filha. Nesse caso específico, pareceu-me que a gravidade do quadro da filha e a lembrança de uma gêmea falecida há 1 ano faziam o diálogo comigo ser doloroso ou desprovido de sentido. Por outro lado, nos serviços de reposição enzimática, fui recebida até de forma efusiva, com uma mistura de curiosidade pelo meu trabalho e alívio pela novidade na rotina tediosa de um hospital. Talvez a esperança trazida pelo tratamento possa estar relacionada ao modo com que fui recebida pelas famílias.

Uma surpresa, contudo, ocorreu ao final de algumas entrevistas. Mesmo dizendo que se preocupavam em saber se seus filhos tinham algum "problema emocional", das crianças que receberam um diagnóstico psiquiátrico atual, muitas recusaram o atendimento oferecido. A justificativa passava, sempre, pela dificuldade de locomoção com as crianças e pela sobrecarga que comparecer "a mais um tratamento" traria sobre a cuidadora.

Isso traz à baila um fato importante, de forma alguma privativo a essa população, mas que, nela, salta aos olhos: o da falta de estruturas de suporte que auxiliem na garantia de bons cuidados a essas crianças e suas famílias. Afinal, existem sérios comprometimentos físicos e de comportamento adaptativo, necessitando sempre de um cuidador.

Esse papel é geralmente desempenhado pela mãe, com poucas exceções. Assim, elas ficam quase que exclusivamente em função do filho doente. Muitas comentam que pararam de trabalhar fora e que dão menos atenção a si mesmas, aos outros familiares (inclusive filhos) e a outras atividades por causa das exigências do cuidado com o filho sindrômico. Como consequência, temos famílias com menor renda e ainda mais dificuldade de acesso a itens como transporte de melhor qualidade e cuidadores profissionais para reduzir a carga materna. 


\section{Considerações Finais}

Pode-se concluir que as mucopolissacaridoses são quadros graves e que possuem diversas repercussões negativas do ponto de vista da maior ocorrência de transtornos mentais em relação à população geral de mesma faixa etária e de alterações de desenvolvimento, com conseqüente redução na autonomia dos indivíduos afetados. Além disso, ocorrem prejuízos significativos nos ambientes familiar e escolar.

Os perfis de desenvolvimento de cada uma das MPS sugerem fenótipos comportamentais específicos para cada uma. Assim, na MPS I, o quoeficiente de desenvolvimento é compatível com retardo mental grave, com prejuízo mais importante nas áreas de atividades de vida diária e motora, sendo que seu funcionamento global evidencia indivíduos com limitações importantes no funcionamento em várias áreas (casa, escola, com pares, sociedade em geral) e incapacidade de funcionar em uma ou mais delas. Na MPS II, o quoeficiente de desenvolvimento encontra-se na faixa de retardo mental leve, com homogeneidade entre os domínios estudados e funcionamento global variando de uma limitação leve em apenas uma área a incapacidade em quase todas as áreas de atuação. Na MPS IV, o quoeficiente de desenvolvimento também é compatível com retardo mental leve, com melhor desempenho na área de socialização e funcionamento global com apenas uma limitação leve em uma área isolada. E, por fim, na MPS VI, o quoeficiente de desenvolvimento encontra-se na faixa de retardo mental leve, com desempenho homogêneo entre os domínios e funcionamento global variando de dificuldades em uma única área a grau moderado de interferência em diversas áreas de desempenho. Devido ao pequeno número de casos das MPS III e VII, não é possível sugerir generalizações a partir dos dados de cada caso.

Para finalizar, cabe lembrar que essas considerações podem ser aplicadas a muitas outras situações em que há crianças deficientes e não só no caso das MPS. Acredito, no entanto, que o fato de esta ser uma síndrome que compromete o desenvolvimento da criança de forma global, com alterações físicas, psíquicas e de comportamento, suscita a questão de que não é apenas de cuidado médico que elas precisam e que esta é uma realidade ainda não contemplada pelos órgãos competentes, seja da saúde, seja da educação. 


\section{Créditos das Fotos}

Fotos 1 a 6: extraídas de Paula, A. C., Kim, C. A., \& Albano, L. M. (2010). Doenças de depósito lisossômico. In: C. A. Kim, L. M. Albano, \& D. R. Bertola, Genética na Prática pediátrica (pp. 503-519). Barueri: Manole. 


\section{Bibliografia}

Albano, L. M., Sugayama, S. S., Bertola, D. R., Andrade, C. E., Utagawa, C. Y., Puppi, F., et al. (2000). Clinical and laboratorial study of 19 cases of mucopolysaccharidoses. Revista do hospital das clínicas da faculdade de medicina da universidade de São Paulo, 55, pp. 213-218.

Alif, N., Hess, K., Straczek, J., Sebbar, S., Belahsen, Y., Mouane, N., et al. (2000).

Mocopolysaccharidose de type I au Maroc: manifestations cliniques et profil génétique. Archives de pédiatrie , 7, pp. 597-604.

APA, A. P. (2000). Diagnostic and Statistic Manual, IV edition, Text Revision.

Assumpção Jr, F. B., Gonçalves, J. D., Cucolicchio, S., Amorim, L. C., Rego, F., Gomes, C., et al. (Maio-agosto de 2008). Escala de avaliação de traços autísticos (ATA): segundo de validade. Medicina de reabilitação, pp. 41-44.

Assumpção Jr, F. B., Kuczynski, E., Gabriel, M. R., \& Rocca, C. C. (1999). Escala de avaliação de traços autísticos (ATA): validade e confiabilidade de uma escala para a detecção de condutas autísticas. Arquivos de neuropsiquiatria , 57, pp. 23-29.

Ayres, M., Ayres Jr, M., Ayres, D. L., \& Santos, A. S. (2001). Bioestat 5.0. Belém: Instituto de desenvolvimento Sustentável Mamirauá.

Barone, R., Fiumara, A., Villani, G. R., Di Natale, P., \& Pavone, L. (2001). Extraneurologic symptoms as presenting signs of Sanfilippo disease. Pediatric neurology, 25, pp. 254-257.

Barone, R., Nigro, F., Triulzi, F., Musumeci, S., Fiumara, A., \& Pavone, L. (october de 1999). Clinical and neuroradiological follow-up in mucopolysaccharidosis type III (Sanfilippo Syndrome). Neuropediatrics, pp. 270-274. 
Bax, M. C., \& Colville, G. A. (1995). Behaviour in mucopolysaccharide disorders. Archives of disease in childhood, 73, pp. 77-81.

Becker, E. (1991). Relatos e retratos de um convívio: estudo exploratório de psicodinamismo em famílias de baixa renda com um integrante com síndrome de Down. Resumos do Congresso interno do IPUSP. São Paulo.

Bernard, P., \& Trouvé, S. (1977). Sémiologie des troubles des conduites sphinctériennes. In: P. Bernard, \& S. Trouvé, Sémiologie psychiatrique (p. 25). Paris: Masson.

Bjoraker, K. J., Delaney, K., Peters, C., Krivit, W., \& Shapiro, E. G. (August de 2006). Longterm outcomes of adaptive functions for children with mucopolysaccharidoses I(Hurler syndrome) treated with hematopoietic stem cell transplantation. Developmental and behavioral pediatrics , 27, pp. 290-296.

Brasil, H. H. (2003). Desenvolvimento da versão brasileira da K-SADS-PL (Schedule for Affective Disorders and Schizophrenia for School-Age Children/Present and Lifetime Version) e estudo de suas propriedades psicométricas. São Paulo, SP, Brasil.

Cicco, M. F., Paiva, M. L., \& Gomes, I. C. (2005). Família e conjugalidade: o sintoma dos filhos frente à imaturidade do casal parental. Psicologia clínica , 17, pp. 53-63.

Cleary, M. A., \& Wraith, J. E. (1993). Management of mucopolysaccharidosis type III. Archives of disease in childhood, 69, pp. 403-406.

Coutinho, M. F., Lacerda, L., \& Alves, S. (2012). Glycosaminoglycan storage disorders: a review. Biochemistry research international, pp. 1-16. 
Cucolicchio, S., Di Matteo, J., Paicheco, R., Gomes, C., Simone, M. F., \& Assumpção Jr, F. B. (2010). Correlação entre as escalas CARS e ATA no diagnóstico de autismo. Medicina de reabilitação, pp. 6-8.

de Paula, A. C., Kim, C. A., \& Albano, L. M. (2010). Doenças de depósito lisossômico. In: C. A. Kim, L. M. Albano, \& D. R. Bertola, Genética na prática pediátrica (pp. 504-519). São Paulo: Manole.

Dhondt, J. L., Farriaux, J. P., Fournier, A., \& Fontaine, G. (1974). Aspects cliniques, radiologiques, biochimiques et genetiques de la maladie de Sanfilippo, a propos de 3 observations. Journal de génétique humaine , 22, pp. 109-132.

Dugas, M., Le Heuzey, M., \& Mayer, M. (1985). Symptomatologie psychotique au cours de l’évolutiondémentielle dúne mucopolysaccharidose de phénotype Hurler-Scheie. Archives françaises de pédiatrie , 42, pp. 373-375.

Handelman, L., Menahem, S., \& Eisenbruch, M. (october de 1989). Transcultural understanding of a hereditary disorder: mucopolysaccharidosis VI in a vietnamese family. Clinical pediatrics (Phila) , 28, pp. 470-473.

Instituto Brasileiro de Geografia e Estatística. (2010). Acesso em 3 de 11 de 2012, disponível em ftp://ftp.ibge.gov.br/Censos/Censo_Demografico_2010/Familias_e_Domicilios/tab1_1.pdf

Jabourian, A. P., Benhamou, P. A., \& Bitton, R. (Janvier de 1996). Imagerie médicale en psychiatrie. Annales médico-psychologiques (Paris), 154, pp. 74-77.

Jones, K. L. (1997). Distúrbios de Armazenamento. In: K. L. Jones, Padrões reconhecíveis de malformações congênitas (pp. 456-471). São Paulo: Manole. 
Kim, W. J., Berger, P., Bunner, S., \& Carey, M. P. (August de 1996). Behavioural manifestations of genetic disorder. Journal od the american academy of child and adolescent psychiatry, 35, pp. 976-977.

Mathiassen, B., Brondbo, P. H., Waterloo, K., Martinussen, M., Eriksen, M., Hansen-Bauer, K., et al. (2012). IQ as a moderator of outcome in severity of children's mental health status after treatment in outpatient clinics. Child and adolescent psychiatry and mental health, pp. 1-7.

Montaño, A. M., Tomatsu, S., Gotterman, G. S., Smith, M., \& Orii, T. (2007). International Morquio A registry: clinical manifestation and natural course of Morquio A disease. Journal of inherited and metabolic diseases, 30, pp. 165-174.

National Institute of Mental Health. (2012). Acesso em 10 de 11 de 2012, disponível em http://www.nimh.nih.gov/science-news/2010/national-survey-confirms-that-youth-aredisproportionately-affected-by-mental-disorders.shtml

National Institute of Mental Health. (2012). Acesso em 10 de 11 de 2012, disponível em http://www.nimh.nih.gov/statistics

Nidiffer, F. D., \& Kelly, T. E. (1983). Developmental and degenerative patterns associated with cognitive, behavioural and motor difficulties in the Sanfilippo syndrome: an epidemiological study. Journal of mental deficiency research , 27, pp. 185-203.

Nunes, M. A. (2010). Consulta terapêutica com pais de crianças autistas: a interface entre a parentalidade e a conjugalidade. Tese de doutorado . São Paulo: Instituto de Psicologia da universidade de são Paulo. 
O’Brien, G., \& Yule, W. (1995). Why behavioural phenotypes? In: G. O’Brien, \& W. Yule, Behavioural phenotypes (pp. 1-23). London: Mac Keith Press.

Omenn, G. S. (June de 1976). Inborn errors of metabolism: clues to understanding human behavioural disorders. Behaviour genetics , 6, pp. 263-284.

Pastores, G. M., Arn, P., Beck, M., Clarke, J. T., Guffon, N., Kaplan, P., et al. (2007). The MPS I registry: design methodology, and early findings of a global disease registry for monitoring patients with mucopolysaccharidoses type I. Molecular genetics and metabolism, 91, pp. 37-47.

Pereira, A., Riesgo, R. S., \& Wagner, M. B. (2008). Childhood autism: translation and validation of the Childhood Autism Rating Scale for use in Brazil. Jornal de pediatria, 84, pp. 487-494.

Pimentel, M. J. (2006). A dinâmica da relação nas fratrias de crianças com doença rara: estudo comparativo entre a síndrome de Cornélia de Lange e a síndrome de Prader-Willi. Tese de mestrado . Lisboa, Portugal: Instituto suoerior de psicologia aplicada.

Robertson, S. P., Klug, G. L., \& Rogers, J. G. (1998). Cerebrospinal fluid shunts in the management of behavioural problems in Sanfilippo syndrome (MPS III). European journal of pediatrics, 157, pp. 653-655.

Sparrow, S. S., Balla, D. A., \& Cicchetti, D. V. (1984). Vineland adaptive behavior scales: interview edition, survey form manual. Minnesota: American Guidance Service.

Ucar, S. K., Ozbaran, B., Demiral, N., Yuncu, Z., Erermis, S., \& Coker, M. (2009). Clinical overview of children with mucopolysaccharidoses type III A and effect of risperidone treatment on children and their mothers psychological status. Brain and development . 
Udwin, O., \& Dennis, J. (1995). Psychological and behavioural phenotypes in genetically determined syndromes: a review of recent findings. In: G. O’Brien, \& W. Yule, Behavioural phenotypes (pp. 137-143). London: Mac Keith Press.

Vieira, T., Schwartz, I., Muñoz, V., Pinto, L., Steiner, C., Ribeiro, M., et al. (2008). Mucopolysaccharidoses in Brazil: what happens from birth to biochemical diagnosis. American journal of medical genetics part A , 146A, pp. 1741-1747.

Winnicott, D. W. (1960). Família e maturidade emocional. In: D. W. Winnicott, A família e o desenvolvimento individual. São Paulo: Martins Fontes.

Wraith, J. E. (1995). The mucopolysaccharidoses: a clinical review and guide to management. Archives of diseases in childhood, 72, pp. 263-267.

Young, I. D., \& Harper, P. S. (1981). Psychosocial problems in Hunter's syndrome. Child: care, healht and development, 7, pp. 201-201.

Young, I. D., Harper, P. S., Newcombe, R. G., \& Archer, I. M. (March de 1982). A clinical and genetic study of Hunter's syndrome. 2 Differences between the mild and severe forms. Journal of medical genetics, 19, pp. 408-411.

Zafeiriou, D. I., Ververi, A., \& Vargiami, E. (2007). Childhood autism and associated comorbidities. Brain \& development, 29, pp. 257-272. 


\title{
Apêndice
}

\author{
INSTITUTO DE PSICOLOGIA \\ DA \\ UNIVERSIDADE DE SÃO PAULO
}

TERMO DE CONSENTIMENTO LIVRE E ESCLARECIDO

I - DADOS DE IDENTIFICAÇÃO DO SUJEITO DA PESQUISA OU RESPONSÁVEL LEGAL

1. NOME DO PACIENTE:

DOCUMENTO DE IDENTIDADE $\mathrm{N}^{\circ}$ : $\quad$ SEXO: M Z F Ž

DATA NASCIMENTO:

ENDEREÇO:

No: APTO:

BAIRRO:

CIDADE:

CEP:

TELEFONE: DDD （ ）

2. RESPONSÁVEL LEGAL:

NATUREZA (grau de parentesco, tutor, curador etc.):

DOCUMENTO DE IDENTIDADE:

SEXO: M Ž F Ž

DATA NASCIMENTO:

ENDEREÇO:

No: $\quad$ APTO:

BAIRRO:

CIDADE:

CEP:

TELEFONE: DDD ( )

II - DADOS SOBRE A PESQUISA CIENTÍFICA

TÍtUlo do PROTOCOLO DE PESQUISA “AVALIAÇÃo do PERFIL PSIQUiÁtRICO DE PACIENTES COM MUCOPOLISSACARIDOSES".

PESQUISADOR: Dra. Tatiana Malheiros Assumpção

INSCRIÇÃO CONSELHO REGIONAL No 109128

CARGO/FUNÇÃO: Pós-graduanda

ORIENTADOR: Prof. Dr. Andrés Eduardo Aguirre Antúnez

AVALIAÇÃO DO RISCO DA PESQUISA: SEM RISCO

DURAÇÃO DA PESQUISA : 2 anos 
III - REGISTRO DAS EXPLICAÇÕES DO PESQUISADOR AO PACIENTE OU SEU REPRESENTANTE LEGAL SOBRE A PESQUISA:

Como já é do seu conhecimento, seu filho tem uma doença genética chamada mucopolissacaridose, causada pela falta de enzima. Este projeto de pesquisa é para verificar se ele tem algum transtorno mental (psiquiátrico). Poderá trazer benefício ao paciente pela possibilidade de deteç̧ão de problemas mentais e de seu tratamento em caso de necessidade, através do encaminhamento para atendimento no Projeto de Distúrbios de Desenvolvimento do Instituto de Psicologia da Universidade de São Paulo.

Será realizada uma única entrevista com os pais e com os pacientes perguntando sobre sintomas de doenças psiquiátricas e sobre o desenvolvimento dos pacientes, através de questionários. O tempo estimado de entrevista é de 2 (duas) horas, podendo variar entre 1 (uma) e 3 (três) horas. Todas as entrevistas serão realizadas pela pesquisadora, após a obtenção do consentimento livre e esclarecido com o paciente e/ou seu responsável. Os instrumentos utilizados serão:

- Schedule for Affective Disorders and Schizophrenia for School-Age Children / Present and Lifetime Version (K-SADS-PL): é uma entrevista semi-estruturada para detectar transtornos psiquiátricos em crianças e adolescentes de 6 a 12 anos.

- Child Global Assessment Scale (CGAS): é uma escala do funcionamento global de crianças de 4 a 16 anos, preenchida pelo examinador.

- Child Autism Rating Scale (CARS): é uma das escalas mais usadas para a detecção do autismo. Divide-se em 14 itens graduados segundo a gravidade dos comportamentos avaliados.

- Escala de Avaliação de Traços Autísticos (ATA): é uma escala para deteç̧ão de autismo composta por 23 partes divididas em vários itens e pode ser aplicada em crianças a partir dos 2 anos de idade.

- Escalas de Comportamento Adaptativo de Vineland: avalia a adaptação social e pessoal dos indivíduos desde a infância até a idade adulta e é aplicável a pessoas com e sem deficiências. Neste estudo será utilizada a versão para triagem, que consiste em 297 itens que medem o desempenho em quatro domínios: comunicação, habilidades de vida diária, socialização e habilidades motoras.

Não há riscos envolvidos na pesquisa. 
IV - ESClARECIMENTOS DADOS PELO PESQUISADOR SOBRE GARANTIAS DO SUJEITO DA PESQUISA:

Terá acesso, a qualquer tempo, às informações sobre procedimentos, riscos e benefícios relacionados à pesquisa, inclusive para dirimir eventuais dúvidas.

É garantida a liberdade de retirar seu consentimento a qualquer momento e de deixar de participar do estudo, sem que isto traga prejuízo à continuidade de seu tratamento na Instituição.

Salvaguarda da confidencialidade, sigilo e privacidade. As informações obtidas serão analisadas em conjunto com outros pacientes, não sendo divulgado a identificação de nenhum paciente.

Direito de ser mantido atualizado sobre os resultados parciais da pesquisa, quando em estudos abertos, ou de resultados que sejam do conhecimento do pesquisador.

Não há despesas pessoais para o participante em qualquer fase do estudo, incluindo exames e consultas. Também não há compensação financeira relacionada a sua participação.

É compromisso do pesquisador utilizar os dados e o material coletado somente para esta pesquisa.

\section{INFORMAÇÕES DE NOMES, ENDEREÇOS E TELEFONES DOS RESPONSÁVEIS PELO ACOMPANHAMENTO DA PESQUISA, PARA CONTATO EM CASO DE NECESSIDADE.}

Dra Tatiana Malheiros Assumpção

Rua dos Otonis, 697, Vila Clementino, São Paulo Fones: 55792762/91381640 


\section{VII - CONSENTIMENTO PÓS-ESCLARECIDO}

Acredito ter sido suficientemente informado a respeito das informações que li ou que foram lidas para mim, descrevendo o estudo: “AVALIAÇÃo DO PERFIL PSIQUiÁtrico DE PACIENTES COM MUCOPOLISSACARIDOSES".

Eu discuti com a Dra. Tatiana Malheiros Assumpção sobre a minha decisão em participar nesse estudo. Ficaram claros para mim quais são os propósitos do estudo, as garantias de confidencialidade e de esclarecimentos permanente. Ficou claro também que minha participação é isenta de despesas e que tenho garantia do acesso a tratamento hospitalar quando necessário. Concordo voluntariamente em participar deste estudo e poderei retirar meu consentimento a qualquer momento, antes ou durante o mesmo, sem penalidades ou prejuízo ou perda de qualquer beneficio que eu possa ter adquirido, ou no meu atendimento neste serviço.

São Paulo, de de .

assinatura do paciente da pesquisa ou responsável legal

assinatura do pesquisador

(carimbo ou nome Legível) 


\section{Anexos}

Nas páginas a seguir, apresentamos os instrumentos utilizados, à exceção da KSADS, devido a sua extensão. 


\section{Escalas de Comportamento Adaptativo de Vineland}

SARA S. SPARROW, DAVID A. BALLA \& DOMENIC V. CICCHETTI - Vineland adaptive behavior scales. Interview Edition - Survey Form. Circle Pines (MN): American Guidance Service, 1984.

Iniciais:

RG-IP:

Data de nascimento:

Data: $-$ 
DOMÍNIO COMUNICACIONAL

\begin{tabular}{|ll|l|}
\hline \multicolumn{2}{|l|}{ PONTUAÇÃO DE ITENS: } & \\
\hline 2 & Sim, freqüentemente. & R: Receptiva \\
1 & Algumas vezes ou parcialmente. & E: Expressiva \\
0 & Não, nunca. & W: Escrita \\
N & Não teve oportunidade. & \\
DK & Não sabe. & \\
\hline
\end{tabular}

\begin{tabular}{|c|c|c|c|c|}
\hline & & $\mathbf{R}$ & E & $\mathbf{W}$ \\
\hline \multirow[t]{8}{*}{$<1$} & 1. Dirige o olhar e a cabeça em direção a um som. & ( ) & & \\
\hline & $\begin{array}{l}\text { 2. Presta atenção ao menos momentaneamente quando } \\
\text { o cuidador Ihe fala. }\end{array}$ & $(）$ & & \\
\hline & 3. Sorri à presença do cuidador. & & ( ) & \\
\hline & $\begin{array}{l}\text { 4. Sorri à presença de outra pessoa familiar que não o } \\
\text { cuidador. }\end{array}$ & & ( ) & \\
\hline & $\begin{array}{l}\text { 5. Ergue os braços quando o cuidador lhe diz: "Venha } \\
\text { cá" ou "De pé". }\end{array}$ & $($ ( ) & & \\
\hline & 6. Demonstra entender o significado do "não". & ( ) & & \\
\hline & $\begin{array}{l}\text { 7. Imita os sons dos adultos imediatamente após ouví- } \\
\text { los. }\end{array}$ & & ( ) & \\
\hline & $\begin{array}{l}\text { 8. Demonstra entender o significado de ao menos } 10 \\
\text { palavras. }\end{array}$ & $($ ) & & \\
\hline \multirow[t]{5}{*}{1} & $\begin{array}{l}\text { 9. Consegue indicar apropriadamente com gestos "sim", } \\
\text { "não" e "eu quero". }\end{array}$ & & ( ) & \\
\hline & 10. Ouve atentamente a comandos. & $($ ) & & \\
\hline & $\begin{array}{l}\text { 11. Demonstra entender o significado de "sim" e "tudo } \\
\text { bem". }\end{array}$ & $($ ( ) & & \\
\hline & 12. Segue ordens que requerem uma ação e um objeto. & ( ) & & \\
\hline & 13. Aponta corretamente para ao menos uma parte & ( ) & & \\
\hline
\end{tabular}




\begin{tabular}{|c|c|c|c|}
\hline & principal do corpo, quando interrogado. & & \\
\hline & $\begin{array}{l}\text { 14. Utiliza os nomes próprios ou apelidos de irmãos, } \\
\text { amigos ou colegas, ou responde seus nomes quando } \\
\text { interrogado. }\end{array}$ & & ( ) \\
\hline & $\begin{array}{l}\text { 15. Utiliza frases contendo um substantivo e um verbo, } \\
\text { ou dois substantivos. }\end{array}$ & & $(）$ \\
\hline & $\begin{array}{l}\text { 16. Nomeia ao menos } 20 \text { objetos familiares sem precisar } \\
\text { ser interrogado. NÃO PONTUE } 1 \text {. }\end{array}$ & & $($ ( ) \\
\hline & 17. Escuta uma história por pelo menos 5 minutos. & $($ ) & \\
\hline & 18. Indica preferência quando submetido a uma escolha. & & ( ) \\
\hline 2 & $\begin{array}{l}\text { 19. Diz ao menos } 50 \text { palavras compreensíveis. NÃO } \\
\text { PONTUE } 1 \text {. }\end{array}$ & & $(）$ \\
\hline & $\begin{array}{l}\text { 20. Relata espontaneamente experiências em linguagem } \\
\text { simples. }\end{array}$ & & $(）$ \\
\hline & 21. Dá um recado simples. & & $($ ( ) \\
\hline & 22. Usa frases de 4 ou mais palavras. & & $(）$ \\
\hline & $\begin{array}{l}\text { 23. Aponta corretamente para todas as partes do corpo } \\
\text { quando interrogado. NÃO PONTUE } 1 \text {. }\end{array}$ & $\left(\begin{array}{l}() \\
\text { ) }\end{array}\right.$ & \\
\hline & $\begin{array}{l}\text { 24. Diz ao menos } 100 \text { palavras compreensíveis. NÃO } \\
\text { PONTUE } 1 \text {. }\end{array}$ & & $($ ) \\
\hline & 25. Utiliza frases completas. & & $($ ( ) \\
\hline & 26. Usa "um(a)" e "o(a)" em frases. & & $(）$ \\
\hline & 27. Segue ordens na forma "se/então". & $(\mathrm{l})$ & \\
\hline & 28. Diz seu nome e sobrenome quando interrogado. & & $(）$ \\
\hline & $\begin{array}{l}\text { 29. Faz perguntas usando "O que", "Aonde", "Quem", } \\
\text { "Por que" e "Quando". NÃO PONTUE } 1 .\end{array}$ & & ( ) \\
\hline 3,4 & $\begin{array}{l}\text { 30. Diz qual de dois objetos é maior sem a presença dos } \\
\text { mesmos. }\end{array}$ & & $(）$ \\
\hline & 31. Relata detalhadamente experiências quando & & $(）$ \\
\hline
\end{tabular}




\begin{tabular}{|c|c|c|c|c|}
\hline & interrogado. & & & \\
\hline & 32. Usa "atrás" ou "entre" como preposição numa frase. & & $($ ) & \\
\hline & 33. Usa "ao redor de" como preposição numa frase. & & ( ) & \\
\hline & 34. Usa frases contendo "mas" e "ou". & & $($ ) & \\
\hline & 35. Articula palavras claramente, sem trocas de fonemas. & & $($ ) & \\
\hline & $\begin{array}{l}\text { 36. Conta histórias populares, contos de fadas, piadas } \\
\text { mais longas ou trechos de "shows" televisivos. }\end{array}$ & & ( ) & \\
\hline \multirow[t]{4}{*}{5} & 37. Cita todas as letras do alfabeto de memória. & & & $($ ( ) \\
\hline & 38. Lê ao menos três sinais comuns. & & & ( ) \\
\hline & $\begin{array}{l}\text { 39. Diz o dia e mês de seu aniversário quando } \\
\text { interrogado. }\end{array}$ & & $($ ) & \\
\hline & 40. Usa plurais irregulares. & & $($ ) & \\
\hline \multirow[t]{7}{*}{6} & 41. Desenha ou escreve seu próprio nome e sobrenome. & & & ( ) \\
\hline & $\begin{array}{l}\text { 42. Diz seu número de telefone quando interrogado. } \mathrm{N} \\
\text { PODE SER PONTUADO. }\end{array}$ & & $($ ) & \\
\hline & $\begin{array}{l}\text { 43. Diz seu endereço completo, incluindo cidade e } \\
\text { estado, quando interrogado. }\end{array}$ & & $($ ) & \\
\hline & 44. Lê ao menos 10 palavras em voz alta ou em silêncio. & & & $($ ( ) \\
\hline & $\begin{array}{l}\text { 45. Desenha ou escreve ao menos } 10 \text { palavras de } \\
\text { memória. }\end{array}$ & & & $($ ) \\
\hline & $\begin{array}{l}\text { 46. Expressa suas idéias em mais de uma maneira, sem } \\
\text { ajuda. }\end{array}$ & & $($ ) & \\
\hline & 47. Lê em voz alta histórias simples. & & & $($ ( ) \\
\hline \multirow[t]{5}{*}{7,8} & $\begin{array}{l}\text { 48. Desenha ou escreve sentenças simples de } 3 \text { ou } 4 \\
\text { palavras. }\end{array}$ & & & ( ) \\
\hline & 49. Assiste a uma aula por pelo menos 15 minutos. & $($ ) & & \\
\hline & 50. Lê por iniciativa própria. & & & $($ ( ) \\
\hline & 51. Lê livros pelo menos da $2^{\mathrm{a}}$ série. & & & ( ) \\
\hline & 52. Ordena itens ou palavras alfabeticamente pela & & & ( ) \\
\hline
\end{tabular}




\begin{tabular}{|c|c|c|c|}
\hline & primeira letra. & & \\
\hline & $\begin{array}{l}\text { 53. Desenha ou escreve pequenos recados ou } \\
\text { mensagens. }\end{array}$ & & ( ) \\
\hline \multirow[t]{4}{*}{9} & 54. Explica itinerários complexos aos outros. & ( ) & \\
\hline & 55. Escreve cartas rudimentares. NÃO PONTUE 1. & & ( ) \\
\hline & 56. Lê livros pelo menos da $4^{a}$ série. & & ( ) \\
\hline & $\begin{array}{l}\text { 57. Escreve em letra de mão a maior parte do tempo. } \\
\text { NÃO PONTUE } 1 .\end{array}$ & & ( ) \\
\hline \multirow{10}{*}{$\begin{array}{ll}10 & a \\
18+ & \end{array}$} & 58. Usa um dicionário. & & ( ) \\
\hline & 59. Usa a relação do conteúdo em material de leitura. & & ( ) \\
\hline & 60. Escreve relatórios ou redações. NÃO PONTUE 1. & & ( ) \\
\hline & 61. Endereça envelopes corretamente. & & ( ) \\
\hline & 62. Usa o índice em material de leitura. & & ( ) \\
\hline & $\begin{array}{l}\text { 63. Lê histórias de jornais adultos. N PODE SER } \\
\text { PONTUADO. }\end{array}$ & & ( ) \\
\hline & $\begin{array}{l}\text { 64. Tem objetivos realísticos a longo-prazo e descreve } \\
\text { com detalhes estratégias para atingí-los. }\end{array}$ & ( ) & \\
\hline & 65. Escreve cartas elaboradas. & & $($ ( ) \\
\hline & $\begin{array}{l}\text { 66. Lê jornais adultos ou magazines semanais. N PODE } \\
\text { SER PONTUADO. }\end{array}$ & & ( ) \\
\hline & 67. Escreve cartas comerciais. NÃO PONTUE 1. & & ( ) \\
\hline
\end{tabular}

\begin{tabular}{|l|l|l|l|l|}
\hline 1. & & & & SOMA: \\
\hline 2. & & & & No N: \\
\hline 3. & & & & No DK: \\
\hline & R & E & W & $\begin{array}{l}\text { Pontuação } \\
\text { geral } \\
\text { subdomínio: }\end{array}$ \\
\hline
\end{tabular}




\section{DOMÍNIO ATIVIDADES DA VIDA COTIDIANA}

\begin{tabular}{|ll|l|}
\hline PONTUAÇÃO DE ITENS: & \\
\hline 2 & Sim, freqüentemente. & P: Pessoal \\
1 & Algumas vezes ou parcialmente. & D: Doméstica \\
0 & Não, nunca. & C: Comunidade \\
N & Não teve oportunidade. & \\
DK & Não sabe. & \\
\hline
\end{tabular}

\begin{tabular}{|c|c|c|c|c|}
\hline & & $\mathbf{P}$ & D & C \\
\hline \multirow[t]{5}{*}{$<1$} & $\begin{array}{l}\text { 1. Demonstra perceber a chegada de mamadeira, seio } \\
\text { materno ou comida. }\end{array}$ & $($ ( ) & & \\
\hline & 2. Abre a boca diante da colher com comida. & $($ ( ) & & \\
\hline & 3. Remove a comida da colher com a boca. & ( ) & & \\
\hline & 4. Engole ou mastiga bolachas. & ( ) & & \\
\hline & 5. Ingere comida sólida. & $(\quad)$ & & \\
\hline \multirow[t]{8}{*}{1} & 6. Bebe de xícara ou copo sem auxílio. & ( ) & & \\
\hline & 7. Alimenta-se com auxílio de colher. & ( ) & & \\
\hline & $\begin{array}{l}\text { 8. Demonstra entender que coisas quentes são } \\
\text { perigosas. }\end{array}$ & & & $($ ( ) \\
\hline & $\begin{array}{l}\text { 9. Indica que está molhado apontando, falando ou } \\
\text { puxando a fralda. }\end{array}$ & $(\quad)$ & & \\
\hline & 10. Bebe por um canudo. & ( ) & & \\
\hline & 11. Permite que o cuidador enxugue seu nariz. & ( ) & & \\
\hline & 12. Alimenta-se com auxílio de garfo. & $($ ( ) & & \\
\hline & $\begin{array}{l}\text { 13. Tira casaco com abertura frontal, suéter ou } \\
\text { camiseta sem auxílio. }\end{array}$ & $($ ) & & \\
\hline \multirow[t]{2}{*}{2} & 14. Alimenta-se com colher sem derramar. & $(\quad)$ & & \\
\hline & $\begin{array}{l}\text { 15. Demonstra interesse em se trocar quando muito } \\
\text { molhado ou sujo. }\end{array}$ & ( ) & & \\
\hline
\end{tabular}




\begin{tabular}{|c|c|c|c|c|}
\hline & 16. Urina na privada ou no penico. & $($ ) & & \\
\hline & 17. Toma banho sem auxílio. & $($ ) & & \\
\hline & 18. Evacua na privada ou no penico. & $($ ) & & \\
\hline & 19. Pede para usar o banheiro. & ( ) & & \\
\hline & 20. Coloca roupas removíveis com faixas de ajuste. & $($ ) & & \\
\hline & 21. Demonstra entender a função do dinheiro. & & & ( ) \\
\hline & 22. Livra-se de seus haveres quando solicitado. & & ( ) & \\
\hline \multirow[t]{9}{*}{3} & 23. Não urina nas vestes à noite. & $($ ) & & \\
\hline & 24. Bebe água da torneira sem auxílio. & $($ ( ) & & \\
\hline & 25. Escova os dentes sem auxílio. NÃO PONTUE 1. & ( ) & & \\
\hline & $\begin{array}{l}\text { 26. Demonstra entender a função do relógio, } \\
\text { convencional ou digital. }\end{array}$ & & & ( ) \\
\hline & 27. Auxilia com mais tarefas se solicitado. & & ( ) & \\
\hline & 28. Lava e enxuga o rosto sem auxílio. & $($ ) & & \\
\hline & 29. Põe os sapatos nos pés corretos sem auxílio. & $($ ) & & \\
\hline & $\begin{array}{l}\text { 30. Atende o telefone adequadamente. N PODE SER } \\
\text { PONTUADO. }\end{array}$ & & & ( ) \\
\hline & 31. Veste-se completamente, exceto amarrar sapatos. & $(）$ & & \\
\hline \multirow[t]{7}{*}{4} & $\begin{array}{l}\text { 32. Chama ao telefone a pessoa solicitada, ou avisa que } \\
\text { esta não se encontra. N PODE SER PONTUADO. }\end{array}$ & & & ( ) \\
\hline & 33. Arruma a mesa das refeições sem auxílio. & & ( ) & \\
\hline & $\begin{array}{l}\text { 34. Toma todas as providências quando vai ao } \\
\text { banheiro, sem precisar ser lembrado e sem auxílio. NÃO } \\
\text { PONTUE } 1 .\end{array}$ & $($ ) & & \\
\hline & $\begin{array}{l}\text { 35. Olha para ambos os lados antes de atravessar rua } \\
\text { ou avenida. }\end{array}$ & & & $($ ) \\
\hline & 36. Tira roupas limpas sem auxílio quando solicitado. & & ( ) & \\
\hline & 37. limpa seu nariz sem auxílio. NÃO PONTUE 1. & $($ ) & & \\
\hline & 38. Limpa mesa com objetos frágeis. & & ( ) & \\
\hline
\end{tabular}




\begin{tabular}{|c|c|c|c|c|}
\hline & 39. enxuga-se com toalha sem auxílio. & ( ) & & \\
\hline & 40. Fecha todos os fechos. NÃO PONTUE 1. & $($ ) & & \\
\hline \multirow[t]{5}{*}{5} & $\begin{array}{l}\text { 41. Ajuda na preparação de alimentos que necessitam } \\
\text { misturar e cozinhar }\end{array}$ & & ( ) & \\
\hline & $\begin{array}{l}\text { 42. Demonstra entender que é perigoso aceitar carona, } \\
\text { comida ou dinheiro de estranhos. }\end{array}$ & & & $($ ) \\
\hline & 43. Dá laço em cadarço de sapato sem auxílio. & $($ ) & & \\
\hline & 44. Toma banho sem auxílio. NÃO PONTUE 1. & ( ) & & \\
\hline & $\begin{array}{l}\text { 45. Olha para ambos os lados e atravessa a rua ou } \\
\text { avenida sozinho(a). }\end{array}$ & & & $($ ( ) \\
\hline & 46. Cobre a boca e o nariz quando tosse ou espirra. & $($ ) & & \\
\hline \multirow[t]{7}{*}{6} & $\begin{array}{l}\text { 47. Usa colher, garfo e faca corretamente. NÃO } \\
\text { PONTUE } 1 .\end{array}$ & $($ ) & & \\
\hline & $\begin{array}{l}\text { 48. Inicia chamadas telefônicas para outrem. N PODE } \\
\text { SER PONTUADO. }\end{array}$ & & & ( ) \\
\hline & $\begin{array}{l}\text { 49. Obedece placas de trânsito e sinais de "Pare" e } \\
\text { "Ande". N PODE SER PONTUADO. }\end{array}$ & & & $($ ( ) \\
\hline & $\begin{array}{l}\text { 50. Veste-se completamente, incluindo amarrar sapatos } \\
\text { e fechar fechos. NÃO PONTUE } 1 .\end{array}$ & $($ ) & & \\
\hline & 51. Arruma sua cama quando solicitado. & & ( ) & \\
\hline & 52. Diz o dia da semana quando solicitado. & & & $($ ) \\
\hline & $\begin{array}{l}\text { 53. Ajusta o cinto de segurança sem ajuda. N PODE } \\
\text { SER PONTUADO. }\end{array}$ & & & $($ ( ) \\
\hline \multirow[t]{4}{*}{7} & 54. Sabe o valor de cada moeda. & & & $($ ( ) \\
\hline & 55. Usa ferramentas básicas. & & ( ) & \\
\hline & 56. Identifica direita e esquerda nos outros. & & & ( ) \\
\hline & 57. Arruma a mesa sem auxílio quando solicitado. & & ( ) & \\
\hline 8 & $\begin{array}{l}\text { 58. Varre, esfrega ou passa o aspirador com cuidado, } \\
\text { sem auxílio, quando solicitado. }\end{array}$ & & $($ ( ) & \\
\hline
\end{tabular}




\begin{tabular}{|c|c|c|c|c|}
\hline & $\begin{array}{l}\text { 59. Usa números de telefone de emergência em } \\
\text { emergências. N PODE SER PONTUADO. }\end{array}$ & & & $($ ( ) \\
\hline & $\begin{array}{l}\text { 60. Pede seu prórpio prato num restaurante. N PODE } \\
\text { SER PONTUADO. }\end{array}$ & & & ( ) \\
\hline & 61. Diz a data de hoje se interrogado. & & & ( ) \\
\hline & $\begin{array}{l}\text { 62. Veste-se antecipando mudanças no tempo sem } \\
\text { precisar ser advertido. }\end{array}$ & $(\quad)$ & & \\
\hline & $\begin{array}{l}\text { 63. Evita pessoas com doenças contagiosas, sem } \\
\text { precisar ser advertido. }\end{array}$ & $\left(\begin{array}{l}() \\
\end{array}\right.$ & & \\
\hline \multirow[t]{4}{*}{9,10} & 64. Fala a hora com intervalos de 5 minutos. & & & ( ) \\
\hline & $\begin{array}{l}\text { 65. Cuida do cabelo sem precisar ser lembrado e sem } \\
\text { auxílio. NÃO PONTUE } 1 .\end{array}$ & $($ ) & & \\
\hline & 66. Usa fogão ou forno de microondas para cozinhar. & & $($ ( ) & \\
\hline & $\begin{array}{l}\text { 67. Usa produtos de limpeza doméstica adequada e } \\
\text { corretamente. }\end{array}$ & & $($ ) & \\
\hline \multirow[t]{4}{*}{11,12} & $\begin{array}{l}\text { 68. Confere corretamente o troco numa compra que } \\
\text { custe mais de um real. }\end{array}$ & & & ( ) \\
\hline & $\begin{array}{l}\text { 69. Usa o telefone para todo tipo de chamadas, sem } \\
\text { auxílio. N PODE SER PONTUADO. }\end{array}$ & & & ( ) \\
\hline & $\begin{array}{l}\text { 70. Cuida de suas unhas sem auxílio e sem precisar ser } \\
\text { advertido. NÃO PONTUE } 1 .\end{array}$ & ( ) & & \\
\hline & $\begin{array}{l}\text { 71. Prepara alimentos que necessitam misturar e } \\
\text { cozinhar, sem auxílio. }\end{array}$ & & $($ ( ) & \\
\hline \multirow[t]{4}{*}{$\begin{array}{ll}13, & 14, \\
15 & \end{array}$} & 72. Usa telefone público. N PODE SER PONTUADO. & & & ( ) \\
\hline & 73. Arruma seu quarto sem precisar ser lembrado. & & $($ ( ) & \\
\hline & 74. Economiza e já comprou ao menos um brinquedo. & & & $($ ( ) \\
\hline & 75. Zela por sua própria saúde. & $($ ) & & \\
\hline 16 & 76. Ganha mesada regularmente. & & & ( ) \\
\hline
\end{tabular}




\begin{tabular}{|c|c|c|c|}
\hline & $\begin{array}{l}\text { 77. Arruma sua cama e troca os lençóis rotineiramente. } \\
\text { NÃO PONTUE } 1 .\end{array}$ & $($ ( ) & \\
\hline & $\begin{array}{l}\text { 78. Limpa outros aposentos que não o seu } \\
\text { regularmente, sem necessitar solicitação. }\end{array}$ & ( ) & \\
\hline & $\begin{array}{l}\text { 79. Realiza tarefas rotineiras de manutenção e reparos } \\
\text { domésticos sem precisar de solicitação. }\end{array}$ & ( ) & \\
\hline 17 a $18+$ & $\begin{array}{l}\text { 80. Costura botões, caseados e ganchos nas roupas } \\
\text { quando solicitado. }\end{array}$ & ( ) & \\
\hline & 81. Faz orçamentos para despesas mensais. & & $($ ) \\
\hline & 82. Cuida de seu dinheiro sem auxílio. & & ( ) \\
\hline & $\begin{array}{l}\text { 83. Planeja e prepara o prato principal do dia sem } \\
\text { auxílio. }\end{array}$ & ( ) & \\
\hline & 84. Chega ao serviço na hora. & & $($ ) \\
\hline & $\begin{array}{l}\text { 85. Toma conta de suas roupas sem precisar ser } \\
\text { lembrado. NÃO PONTUE } 1 \text {. }\end{array}$ & ( ) & \\
\hline & $\begin{array}{l}\text { 86. Notifica seu supervisor se vai se atrasar para } \\
\text { chegar. }\end{array}$ & & ( ) \\
\hline & $\begin{array}{l}\text { 87. Notifica seu supervisor se vai se ausentar por } \\
\text { doença. }\end{array}$ & & ( ) \\
\hline & 88. Faz orçamentos para despesas mensais. & & $($ ) \\
\hline & $\begin{array}{l}\text { 89. Faz as próprias bainhas e outras alterações sem } \\
\text { precisar ser advertido. }\end{array}$ & ( ) & \\
\hline & $\begin{array}{l}\text { 90. Obedece limites de tempo para café e almoço no } \\
\text { trabalho. }\end{array}$ & & ( ) \\
\hline & $\begin{array}{l}\text { 91. assume trabalho em tempo integral com } \\
\text { responsabilidade. NÃO PONTUE } 1 .\end{array}$ & & ( ) \\
\hline & $\begin{array}{l}\text { 92. Tem conta bancária e a movimenta com } \\
\text { responsabilidade. }\end{array}$ & & ( ) \\
\hline
\end{tabular}




\begin{tabular}{|l|l|l|l|l|}
\hline 1. & & & & SOMA: \\
\hline 2. & & & & No N: \\
\hline 3. & & & & No DK: \\
\hline & P & D & C & $\begin{array}{l}\text { Pontuação } \\
\text { geral } \\
\text { subdomínio: }\end{array}$ \\
\hline
\end{tabular}


DOMÍNIO SOCIALIZAÇÃO

\begin{tabular}{|ll|l|}
\hline \multicolumn{2}{|l|}{ PONTUAÇÃO DE ITENS: } & \\
\hline 2 & Sim, freqüentemente. & IR: Relações Inter-pessoais \\
1 & Algumas vezes ou parcialmente. & PLT: Brincar e Lazer \\
0 & Não, nunca. & CS: Habilidades Sociais \\
N & Não teve oportunidade. & \\
DK & Não sabe. & \\
\hline
\end{tabular}

\begin{tabular}{|c|c|c|c|c|}
\hline & & IR & PLT & CS \\
\hline \multirow[t]{14}{*}{$<1$} & 1. Olha para o rosto do cuidador. & ( ) & & \\
\hline & 2. Reage à voz do cuidador ou de outra pessoa. & ( ) & & \\
\hline & 3. Distingue o cuidador dos outros. & ( ) & & \\
\hline & $\begin{array}{l}\text { 4. Demonstra interesse em objetos ou pessoas } \\
\text { novas. }\end{array}$ & & $($ ) & \\
\hline & $\begin{array}{l}\text { 5. Expressa duas ou mais emoções compreensíveis } \\
\text { como prazer, tristeza, medo ou aflição. }\end{array}$ & $($ ( ) & & \\
\hline & $\begin{array}{l}\text { 6. Antecipa-se ao sinal de que vai ser pego ao colo } \\
\text { pelo cuidador. }\end{array}$ & $($ ) & & \\
\hline & 7. Demonstra afeição para com pessoas familiares. & ( ) & & \\
\hline & $\begin{array}{l}\text { 8. Demonstra interesse em outras crianças que não } \\
\text { seus irmãos. }\end{array}$ & & $($ ) & \\
\hline & 9. Dirige-se a pessoa conhecida. & $($ ( ) & & \\
\hline & $\begin{array}{l}\text { 10. Brinca com brinquedo ou outro objeto só ou } \\
\text { acompanhado. }\end{array}$ & & $(）$ & \\
\hline & $\begin{array}{l}\text { 11. Participa de jogos simples de interação com } \\
\text { outras crianças. }\end{array}$ & & $(）$ & \\
\hline & 12. Utiliza objetos domésticos para brincar. & & () & \\
\hline & 13. Demonstra interesse nas atividades dos outros. & & $($ ) & \\
\hline & 14. Imita movimentos simples dos adultos, como & ( ) & & \\
\hline
\end{tabular}




\begin{tabular}{|c|c|c|c|c|}
\hline & $\begin{array}{l}\text { bater palmas ou acenar um adeus, em resposta a um } \\
\text { modelo. }\end{array}$ & & & \\
\hline \multirow[t]{7}{*}{1,2} & $\begin{array}{l}\text { 15. Ri e sorri adequadamente em resposta a } \\
\text { estímulos positivos. }\end{array}$ & ( ) & & \\
\hline & $\begin{array}{l}\text { 16. Identifica ao menos duas pessoas familiares pelo } \\
\text { nome. }\end{array}$ & ( ) & & \\
\hline & 17. demonstra desejo de agradar o cuidador. & ( ) & & \\
\hline & $\begin{array}{l}\text { 18. Participa de ao menos uma atividade ou jogo em } \\
\text { grupo. }\end{array}$ & & ( ) & \\
\hline & $\begin{array}{l}\text { 19. Imita uma tarefa relativamente complexa várias } \\
\text { horas após ter sido realizada por alguém. }\end{array}$ & $($ ) & & \\
\hline & $\begin{array}{l}\text { 20. Imita frases de adultos ouvidas em ocasiões } \\
\text { prévias. }\end{array}$ & () & & \\
\hline & $\begin{array}{l}\text { 21. Empenha-se em criar situações de "faz-de- } \\
\text { conta", só ou acompanhado. }\end{array}$ & & $($ ) & \\
\hline \multirow[t]{4}{*}{3} & $\begin{array}{l}\text { 22.Demonstra preferência por alguns amigos em } \\
\text { detrimento de outros. }\end{array}$ & $($ ) & & \\
\hline & 23. Diz "Por favor" ao pedir algo. & & & $($ ( ) \\
\hline & $\begin{array}{l}\text { 24. Qualifica felicidade, tristeza, medo e raiva em si } \\
\text { mesmo. }\end{array}$ & $($ ) & & \\
\hline & $\begin{array}{l}\text { 25. Identifica pessoas por características outras que } \\
\text { não o nome, quando solicitado. }\end{array}$ & ( ) & & \\
\hline \multirow[t]{3}{*}{4} & $\begin{array}{l}\text { 26. Compartilha brinquedos e objetos sem necessitar } \\
\text { solicitação. }\end{array}$ & & $($ ) & \\
\hline & $\begin{array}{l}\text { 27. Nomeia um ou mais programas favoritos de } \\
\text { televisão quando solicitado, e diz em que dias e } \\
\text { canais os programas são apresentados. N PODE SER } \\
\text { PONTUADO. }\end{array}$ & & ( ) & \\
\hline & 28. Segue regras em jogos simples sem precisar ser & & $($ ) & \\
\hline
\end{tabular}




\begin{tabular}{|c|c|c|c|c|}
\hline & lembrado. & & & \\
\hline & 29. Tem um amigo predileto de qualquer sexo. & $($ ) & & \\
\hline & 30. Segue as regras e rotinas escolares. & & & ( ) \\
\hline \multirow[t]{4}{*}{5} & $\begin{array}{l}\text { 31. reage verbalmente e positivamente ao bom } \\
\text { resultado dos outros. }\end{array}$ & $(\quad)$ & & \\
\hline & 32. Pede perdão por erros involuntários. & & & $($ ) \\
\hline & 33. Tem um grupo de amigos. & ( ) & & \\
\hline & 34. Segue as regras da comunidade. & & & ( ) \\
\hline \multirow[t]{4}{*}{6} & $\begin{array}{l}\text { 35. Joga mais de um jogo de mesa ou jogo de } \\
\text { baralho que necesite habilidade e decisão. }\end{array}$ & & ( ) & \\
\hline & 36. Não fala com a boca cheia. & & & ( ) \\
\hline & 37. Tem um amigo do peito do mesmo sexo. & $(）$ & & \\
\hline & $\begin{array}{l}\text { 38. Reage adequadamente quando apresentado a } \\
\text { alguém. }\end{array}$ & & & ( ) \\
\hline \multirow[t]{4}{*}{7,8} & $\begin{array}{l}\text { 39. Faz ou compra pequenos presentes para o } \\
\text { cuidador ou membro da família em datas festivas, } \\
\text { por iniciativa própria. }\end{array}$ & $(\quad)$ & & \\
\hline & $\begin{array}{l}\text { 40. Mantém segredos e confidências por mais de um } \\
\text { dia. }\end{array}$ & & & ( ) \\
\hline & $\begin{array}{l}\text { 41. Devolve brinquedos, objetos ou dinheiro } \\
\text { emprestado de um colega e devolve livros } \\
\text { emprestados à biblioteca. }\end{array}$ & & & ( ) \\
\hline & 42. Termina a conversa adequadamente. & & & ( ) \\
\hline \multirow[t]{4}{*}{9} & 43. Segue limites de tempo impostos pelo cuidador. & & & $($ ) \\
\hline & $\begin{array}{l}\text { 44. Evita perguntas ou comentários que possam } \\
\text { embaraçar ou magoar os outros. }\end{array}$ & & & ( ) \\
\hline & 45. Controla raiva e mágoa quando Ihe é negado. & & & $($ ) \\
\hline & $\begin{array}{l}\text { 46. Mantém segredos e confidências tanto quanto for } \\
\text { apropriado. }\end{array}$ & & & ( ) \\
\hline
\end{tabular}




\begin{tabular}{|c|c|c|c|c|}
\hline 10,11 & $\begin{array}{l}\text { 47. Comporta-se adequadamente à mesa sem } \\
\text { precisar ser advertido. NÃO PONTUE } 1 .\end{array}$ & & & ( ) \\
\hline & $\begin{array}{l}\text { 48. Assiste TV ou ouve rádio em busca de } \\
\text { informação sobre uma área de interesse em } \\
\text { particular. N PODE SER PONTUADO. }\end{array}$ & & ( ) & \\
\hline & $\begin{array}{l}\text { 49. Vai à escola noturna ou eventos fechados com } \\
\text { amigos, quando acompanhado de um adulto. N } \\
\text { PODE SER PONTUADO. }\end{array}$ & & $($ ( ) & \\
\hline & $\begin{array}{l}\text { 50. Pesa as consequências das ações antes de tomar } \\
\text { decisões com independência. }\end{array}$ & & & ( ) \\
\hline & 51. Pede perdão por erros em seu julgamento. & & & ( ) \\
\hline 13 & $\begin{array}{l}\text { 52. Lembra datas de aniversário de membros } \\
\text { próximos da família e amigos em particular. }\end{array}$ & () & & \\
\hline & $\begin{array}{l}\text { 53. Inicia conversas sobre tópicos de especial } \\
\text { interesse para os outros. }\end{array}$ & () & & \\
\hline & 54. Tem um "hobby". & & ( ) & \\
\hline & 55. Devolve dinheiro emprestado do cuidador. & & & ( ) \\
\hline 15 a $18+$ & $\begin{array}{l}\text { 56. Reage a alusões e indiretas durante a } \\
\text { conversação. }\end{array}$ & () & & \\
\hline & $\begin{array}{l}\text { 57. Participa de esportes extra-curriculares. N PODE } \\
\text { SER PONTUADO. }\end{array}$ & & $($ ) & \\
\hline & $\begin{array}{l}\text { 58. Assiste TV ou ouve rádio para informações } \\
\text { práticas e cotidianas. N PODE SER PONTUADO. }\end{array}$ & & $($ ) & \\
\hline & 59. Agenda e respeita agendamentos. & & & $($ ) \\
\hline & $\begin{array}{l}\text { 60. Assiste TV ou ouve rádio buscando notícias } \\
\text { independentemente. N PODE SER PONTUADO. }\end{array}$ & & $($ ) & \\
\hline & $\begin{array}{l}\text { 61. Vai à escola noturna ou eventos fechados com } \\
\text { amigos, sem acompanhamento de um adulto. } \mathrm{N} \\
\text { PODE SER PONTUADO. }\end{array}$ & & $($ ) & \\
\hline
\end{tabular}




\begin{tabular}{|l|l|l|l|l|}
\hline & $\begin{array}{l}\text { 62. Sai à noite com amigos, sem supervisão de um } \\
\text { adulto. }\end{array}$ & $($ ) & \\
\hline $\begin{array}{l}\text { 63. Pertence a uma organização social ou de } \\
\text { serviços, grupo de interesses ou clube organizado de } \\
\text { adolescentes mais velhos. }\end{array}$ & $\begin{array}{l}\text { 64. Vai com uma só pessoa do sexo oposto a festas } \\
\text { ou eventos públicos onde muitas pessoas estarão } \\
\text { presentes. }\end{array}$ & & & \\
\hline & $\begin{array}{l}\text { 65. Sai em grupos de dois ou três casais. } \\
\text { 66. Sai para encontros a sós. }\end{array}$ & $($ ) & & \\
\hline
\end{tabular}

\begin{tabular}{|l|l|l|l|l|}
\hline 1. & & & & SOMA: \\
\hline 2. & & & & No N: \\
\hline 3. & & & & No DK: \\
\hline & IR & PLT & CS & $\begin{array}{l}\text { Pontuação } \\
\text { geral } \\
\text { subdomínio: }\end{array}$ \\
\hline
\end{tabular}




\section{DOMÍNIO HABILIDADES MOTORAS}

\begin{tabular}{|ll|l|}
\hline PONTUAÇÃO DE ITENS: & \\
\hline 2 & Sim, freqüentemente. & G: Grosseira \\
1 & Algumas vezes ou parcialmente. & F: Fina \\
0 & Não, nunca. & \\
N & Não teve oportunidade. & \\
DK & Não sabe. & \\
\hline
\end{tabular}

\begin{tabular}{|c|c|c|c|}
\hline & & G & $\mathbf{F}$ \\
\hline \multirow[t]{8}{*}{$<1$} & $\begin{array}{l}\text { 1. Mantém a cabeça ereta pelo menos } 15 \text { segundos sem auxílio } \\
\text { quando sustentado verticalmente pelos braços do examinador. }\end{array}$ & $(）$ & \\
\hline & 2. Senta com apoio por pelo menos 1 minuto. & ( ) & \\
\hline & 3. Agarra pequenos objetos com as mãos, de qualquer jeito. & & $($ ) \\
\hline & 4. Transfere objetos de uma mão para a outra. & & $($ ( ) \\
\hline & 5. Agarra pequenos objetos com o polegar e os dedos. & & $($ ) \\
\hline & $\begin{array}{l}\text { 6. Soergue-se para a posição sentada e mantém a posição por } \\
\text { pelo menos } 1 \text { minuto. }\end{array}$ & $($ ) & \\
\hline & $\begin{array}{l}\text { 7. Engatinha pelo chão sobre as mãos e os joelhos, sem } \\
\text { encostar a barriga no chão. }\end{array}$ & $($ ) & \\
\hline & 8. Abre portas que só necessitam ser empurradas ou puxadas. & & $($ ) \\
\hline \multirow[t]{5}{*}{1} & 9. Rola uma bola enquanto sentado. & ( ) & \\
\hline & 10. Anda com o objetivo de explorar os arredores. & ( ) & \\
\hline & 11. Sobe e desce da cama ou de uma cadeira grande. & ( ) & \\
\hline & 12. Sobe em brinquedos baixos. & ( ) & \\
\hline & 13. Rabisca com lápis, crayon ou giz em superfícies. & & $($ ) \\
\hline \multirow[t]{3}{*}{2} & 14. Sobe escadas, apoiando os dois pés em cada degrau. & $($ ) & \\
\hline & $\begin{array}{l}\text { 15. Desce escada de frente, apoiando os dois pés em cada } \\
\text { degrau. }\end{array}$ & $($ ) & \\
\hline & 16. Corre graciosamente, com mudanças de velocidade e & ( ) & \\
\hline
\end{tabular}




\begin{tabular}{|c|c|c|c|}
\hline & direção. & & \\
\hline & 17. Abre portas, girando e empurrando maçanetas. & & ( ) \\
\hline & 18. Pula sobre objetos pequenos. & ( ) & \\
\hline & 19. Atarracha e desatarracha a tampa de um pote.. & & $($ ( ) \\
\hline & $\begin{array}{l}\text { 20. Pedala triciclo ou outro veículo de três rodas por pelo } \\
\text { menos três pés. N PODE SER PONTUADO. }\end{array}$ & ( ) & \\
\hline & $\begin{array}{l}\text { 21. Mantém-se sobre um só pé, enquanto se segura em outra } \\
\text { pessoa ou objeto estável, sem cair. }\end{array}$ & $(）$ & \\
\hline & $\begin{array}{l}\text { 22. Constrói estruturas em três dimensões, com no mínimo } 5 \\
\text { blocos. }\end{array}$ & & $($ ( ) \\
\hline & 23. Abre e fecha tesoura com uma mão. & & ( ) \\
\hline $3,4+$ & 24. Desce escada sem auxílio, alternando os pés. & $($ ( ) & \\
\hline & 25. Sobe em brinquedos altos. & $($ ( ) & \\
\hline & 26. Recorta papel com tesoura. & & $($ ( ) \\
\hline & $\begin{array}{l}\text { 27. Salta em um pé só pelo menos três vezes sem perder o } \\
\text { embalo. NÃO PONTUE } 1 .\end{array}$ & ( ) & \\
\hline & $\begin{array}{l}\text { 28. Completa quebra-cabeça de pelo menos } 6 \text { peças. NÃO } \\
\text { PONTUE } 1 .\end{array}$ & & ( ) \\
\hline & $\begin{array}{l}\text { 29. Desenha mais de uma forma identificável com lápis ou } \\
\text { crayons. }\end{array}$ & & $($ ( ) \\
\hline & 30. Recorta papel seguindo uma linha com a tesoura. & & ( ) \\
\hline & 31. Usa a borracha sem rasgar o papel. & & ( ) \\
\hline & 32. Pula em um pé só com facilidade. NÃO PONTUE 1. & $($ ( ) & \\
\hline & 33. Destranca fechaduras. & & $($ ) \\
\hline & 34. Recorta figuras complexas com tesoura. & & ( ) \\
\hline & $\begin{array}{l}\text { 35. Apanha bola pequena arremessada de uma distância de } 10 \\
\text { pés, mesmo que necessite se mover para isso. }\end{array}$ & $(）$ & \\
\hline & $\begin{array}{l}\text { 36. Anda numa bicicleta sem rodinhas de segurança, sem cair. } \\
\text { N PODE SER PONTUADO. }\end{array}$ & ( ) & \\
\hline
\end{tabular}




\begin{tabular}{|l|l|l|l|}
\hline 1. & & & SOMA: \\
\hline 2. & & & No N: \\
\hline 3. & & & No DK: \\
\hline & G & F & $\begin{array}{l}\text { Pontuação } \\
\text { geral } \\
\text { subdomínio: }\end{array}$ \\
\hline
\end{tabular}

DOMÍNIO COMPORTAMENTO DISRUPTIVO

\begin{tabular}{|ll|}
\hline \multicolumn{2}{|l|}{ PONTUAÇÃO DE ITENS: } \\
\hline 2 & Sim, freqüentemente. \\
1 & Algumas vezes ou parcialmente. \\
0 & Não, nunca. \\
$N$ & Não teve oportunidade. \\
DK & Não sabe. \\
\hline
\end{tabular}

\section{PARTE 1}

\begin{tabular}{|l|l|}
\hline 1. Suga polegar ou dedos. & () \\
\hline 2. É dependente demais. & () \\
\hline 3. Esconde-se. & () \\
\hline 4. Urina na cama. & () \\
\hline 5. Apresenta distúrbio alimentar. & ( \\
\hline 6. Apresenta distúrbio do sono. & () \\
\hline 7. Rói unhas. & ( \\
\hline 8. Evita a escola ou o trabalho. & ( \\
\hline 9. Demonstra acentuada ansiedade. & ( \\
\hline 10. Apresenta tiques. & () \\
\hline 11. Chora ou ri muito facilmente. & ( \\
\hline 12. Tem pouco contato com o olhar. & () \\
\hline
\end{tabular}




\begin{tabular}{|c|c|}
\hline 13. Apresenta infelicidade excessiva. & ( ) \\
\hline 14. Range dentes durante o dia ou a noite. & ( ) \\
\hline 15. É muito impulsivo. & $($ ) \\
\hline 16. Pouca capacidade de prestar atenção e concentração. & $($ ( ) \\
\hline 17. É demasiadamente ativo. & $($ ( ) \\
\hline 18. Tem crises de birra. & ( ) \\
\hline 19. É negativista ou desafiador. & $($ ) \\
\hline 20. Atormenta ou ameaça. & $($ ( ) \\
\hline 21. Demonstra falta de consideração. & $($ ( ) \\
\hline 22. Mente, trapaceia ou rouba. & $($ ) \\
\hline 23. É fisicamente muito agressivo. & ( ) \\
\hline 24. Sua em situações inapropriadas. & $($ ) \\
\hline 25. Foge. & $($ ) \\
\hline 26. É teimoso ou mal-humorado. & ( ) \\
\hline 27. É gazeteiro na escola ou trabalho. & $($ ) \\
\hline
\end{tabular}

\section{PARTE 2}

INTENSIDADE CIRCUNDE UMA DELAS

\begin{tabular}{|l|l|l|l|}
\hline $\begin{array}{l}\text { 28. Envolve-se em comportamento sexual } \\
\text { inadequado. }\end{array}$ & & GRAVE & MODERADO \\
\hline $\begin{array}{l}\text { 29. Tem preocupações excessivas ou peculiares } \\
\text { com objetos ou atividades. }\end{array}$ & S ) & S & M \\
\hline $\begin{array}{l}\text { 30. Expressa pensamentos que não são sensatos. } \\
\text { 31. Demonstra maneirismos ou hábitos } \\
\text { extremamente peculiares. }\end{array}$ & ( ) & S & M \\
\hline $\begin{array}{l}\text { 32. Apresenta comportamentos lesivos contra si } \\
\text { mesmo. }\end{array}$ & ） & S & M \\
\hline
\end{tabular}




\begin{tabular}{|l|l|l|l|}
\hline $\begin{array}{l}\text { 33. Destrói intencionalmente propriedade própria } \\
\text { ou alheia. }\end{array}$ & S & S & M \\
\hline 34. Apresenta discurso bizarro. & ( ) & S & M \\
\hline $\begin{array}{l}\text { 35. Alheia-se do que se passa ao seu redor. } \\
\text { 36. Balança o ronco para frente e para trás } \\
\text { quando sentado ou parado. }\end{array}$ & S & S & M \\
\hline
\end{tabular}

SOMA (PARTE 1 e 2): 


\section{Escala de Pontuação do Autismo}

Schopler E, Renner BR, 1988

ESCALA DE PONTUAÇÃO DO AUTISMO

(Childhood Autism Rating Scale - CARS)

NOME:

RG:

SEXO: $\quad M$

$\mathbf{F}$

IDADE:

DN:

DATA DA AVALIAÇÃO:

\section{RESULTADO:}

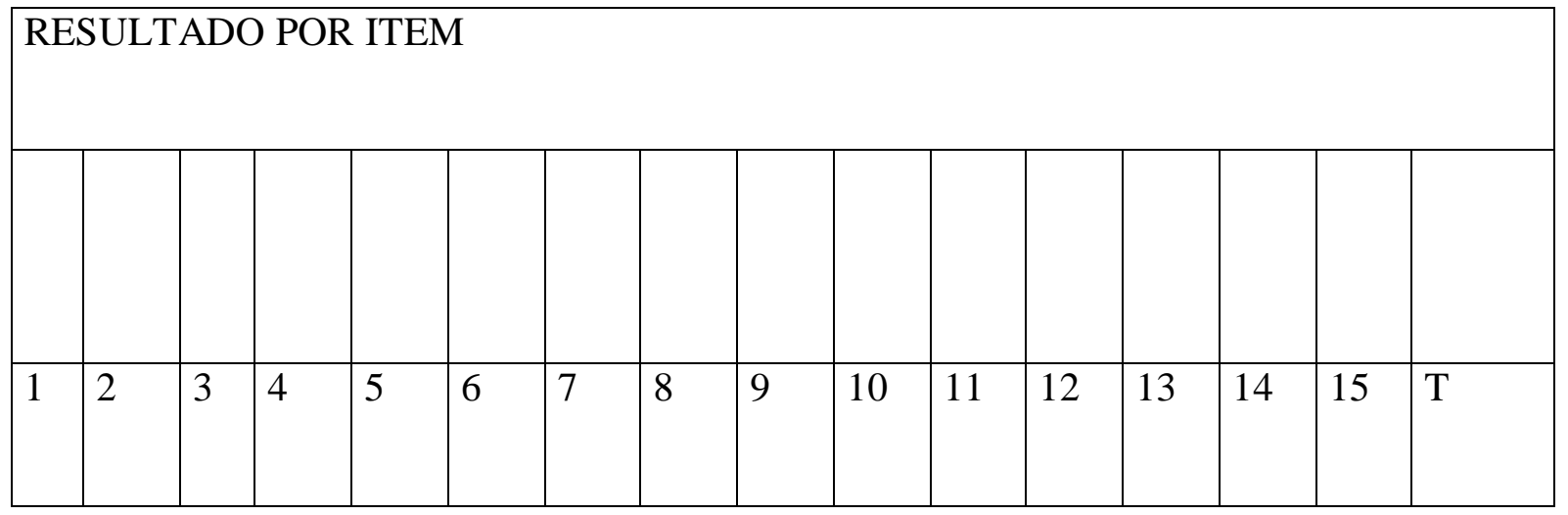

RESULTADO FINAL

Normal: $15-29,5$

Autismo leve/ moderado: 30 - $\mathbf{3 6 , 5}$

Autismo grave: acima de 37

\section{1- RELACIONAMENTO INTER-PESSOAL}




\begin{tabular}{|l|l|}
\hline Pontos & Sintomas \\
\hline 1 & $\begin{array}{l}\text { Sem evidência de dificuldade ou anormalidade: comportamento adequado } \\
\text { para a idade. Pode existir timidez, inquietude, mas em níveis similares ao } \\
\text { observados em crianças da mesma idade. }\end{array}$ \\
\hline 1,5 & $\begin{array}{l}\text { Anormalidade Leve: A criança evita olhar o adulto nos olhos e demonstra } \\
\text { dificuldades quando é forçado a tal; extremamente tímido; dificuldades no trato } \\
\text { social com os adultos, quando comparado aos de sua idade; agarra-se mais } \\
\text { intensamente aos familiares que os demais. }\end{array}$ \\
\hline 2 & $\begin{array}{l}\text { Anormalidade Moderada: Em certos momentos, a criança se isola. Necessita } \\
\text { reforço persistente para manter sua atenção. Pouca iniciativa para contatos e } \\
\text { contato impessoal. }\end{array}$ \\
\hline 3,5 & $\begin{array}{l}\text { Anormalidade Grave: Isola-se de fato, não percebendo o que o adulto faz; } \\
\text { nunca responde às iniciativas do adulto ou inicia um contato. Apenas tentativas } \\
\text { intensas para chamar sua atenção tem algum efeito positivo. }\end{array}$ \\
\hline 3,5 & \\
\hline 4 &
\end{tabular}




\begin{tabular}{|l|l|}
\hline 2 - IMITAÇ̃̃O \\
\hline Pontos & Sintomas \\
\hline 1 & $\begin{array}{l}\text { Adequada: Imita sons, palavras e movimentos próprios de sua etapa de } \\
\text { desenvolvimento. }\end{array}$ \\
\hline 1,5 & $\begin{array}{l}\text { Anormalidade leve: Imita comportamentos simples, tais como: bater palmas, } \\
\text { falar palavras isoladamente. Às vezes reproduz um gesto após certo tempo de } \\
\text { latência. }\end{array}$ \\
\hline 2,5 & $\begin{array}{l}\text { Anormalidade Moderada: Só imita às vezes e. mesmo assim, após grande } \\
\text { insistência e auxílio do adulto. Reproduz com frequiência e atraso a imitação de } \\
\text { alguns gestos. }\end{array}$ \\
\hline 3 & $\begin{array}{l}\text { Anormalidade Grave: Imita sons, palavras e gestos dos adultos muito } \\
\text { raramente e com grande latência no tempo, ou nunca. }\end{array}$ \\
\hline 3,5 & \\
\hline 4 &
\end{tabular}

\begin{tabular}{|l|l|}
\hline 3 - RESPOSTA EMOCIONAL \\
\hline Pontos & Sintomas \\
\hline 1 & $\begin{array}{l}\text { Adequada para cada situação e de acordo com sua idade: Emocionalmente } \\
\text { mostra sintonia entre as expressões faciais, posturas corporais e } \\
\text { comportamento. }\end{array}$ \\
\hline 1,5 & $\begin{array}{l}\text { Anormalidade Leve: Ocasionalmente demonstra alguma inadequação na forma } \\
\text { e intensidade de suas reações emocionais. Algumas reações não se relacionam } \\
\text { a objetos ou acontecimentos do entorno. }\end{array}$ \\
\hline 2,5 & $\begin{array}{l}\text { Anormalidade Moderada: Presença definitiva de sinais inapropriados, na forma } \\
\text { e intensidade, de suas reações emocionais que podem ser inibidas, exageradas } \\
\text { e, algumas vezes, sem relação com as situações vividas no momento. Faz } \\
\text { caretas, ri ou fica parado sem que existam acontecimentos que justifiquem tais }\end{array}$ \\
\hline 3 &
\end{tabular}




\begin{tabular}{|l|l|}
\hline & reações. \\
\hline 3,5 & $\begin{array}{l}\text { Anormalidade Grave: Raramente as respostas emocionais são adequadas às } \\
\text { situações. Difícil a mudança de humor, mesmo que se mudem as condições que } \\
\text { o geraram. Grande diversidade de reações emocionais em espaços curtos de } \\
\text { tempo, sem que ocorram mudanças no meio que as justifiquem. }\end{array}$ \\
\hline
\end{tabular}




\begin{tabular}{|l|l|}
\hline 4 - EXPRESS ÃO CORPORAL \\
\hline Pontos & Sintomas \\
\hline 1 & $\begin{array}{l}\text { Adequada: Movimentação fácil, agilidade e coordenação em acordo com a } \\
\text { idade. }\end{array}$ \\
\hline 1,5 & $\begin{array}{l}\text { Anormalidade Leve: Peculiaridades menores podem estar presentes, tais como: } \\
\text { movimentos desajeitados, coordenação pobre, ou presença de movimentos } \\
\text { inusitados (descritos no próximo item). }\end{array}$ \\
\hline 2 & $\begin{array}{l}\text { Anormalidade Moderada: Comportamento nitidamente estranhos, inusitados } \\
\text { nas outras crianças de sua idade. Posturas peculiares dos dedos } \\
\text { (serpenteamentos) ou do corpo, fenômenos de auto-agressão, balanceios, } \\
\text { movimentos giratórios, contorcionismos, andar na ponta dos pés, etc. }\end{array}$ \\
\hline 3 & $\begin{array}{l}\text { Anormalidade Grave: os movimentos descritos no item anterior podem estar } \\
\text { presentes de maneira persistente, a despeito de tentativas persistentes de } \\
\text { tempo em que se envolve com algumas atividades. }\end{array}$ \\
\hline 3,5 & \begin{tabular}{l} 
modicar seu comportamento corporal e podem persistir mesmo durante o \\
\hline 4
\end{tabular}
\end{tabular}

\begin{tabular}{|l|l|}
\hline 5- USO DE OBJETOS \\
\hline Pontos & Sintomas \\
\hline 1 & $\begin{array}{l}\text { Uso e interesse adequados: A criança demonstra interesse adequado em } \\
\text { brinquedos e outros objetos relacionados ao seu nível de desenvolvimento. Há } \\
\text { uso funcional dos brinquedos. }\end{array}$ \\
\hline 1,5 & $\begin{array}{l}\text { Anormalidade Leve: Demonstra um interesse menor pelos brinquedos além de } \\
\text { manipulação e uso inadequado dos mesmos (golpeia os objetos ou leva à boca). }\end{array}$ \\
\hline 2 & $\begin{array}{l}\text { Anormalidade Moderada: Pouco interesse pelos brinquedos e objetos em geral } \\
\text { e seu uso é pouco funcional. Pode interessar-se muito particularmente por uma }\end{array}$ \\
\hline 3 &
\end{tabular}




\begin{tabular}{|l|l|}
\hline & $\begin{array}{l}\text { parte do brinquedo, ficar fascinado pelo reflexo da luz sobre o objeto, ou eleger } \\
\text { apenas e exclusivamente um certo objeto, excluindo os demais. Esse } \\
\text { comportamento pode ser parcial e temporariamente modificável. }\end{array}$ \\
\hline 3,5 & $\begin{array}{l}\text { Anormalidade Grave: Pode apresentar os sintomas descritos no item anterior } \\
\text { com maior intensidade e frequiência. É difícil distrair sua atenção quando está } \\
\text { "ocupada” com essas atividades inadequadas e muito difícil modificar o uso } \\
\text { inadequado dos objetos. }\end{array}$ \\
\hline 4
\end{tabular}




\begin{tabular}{|c|c|}
\hline \multicolumn{2}{|c|}{ 6- ADAPTAÇÃO A MUDANÇAS } \\
\hline Pontos & Sintomas \\
\hline 1 & $\begin{array}{l}\text { Sem anormalidade: Apesar da criança notar e comentar sobre as mudanças de } \\
\text { rotina, há uma aceitação sem grandes distúrbios. }\end{array}$ \\
\hline \multicolumn{2}{|l|}{1,5} \\
\hline 2 & $\begin{array}{l}\text { Anormalidade Leve: Quando o adulto tenta modificar algumas rotinas, a } \\
\text { criança continua com a mesma atividade ou no uso dos mesmos materiais, mas } \\
\text { pode ficar facilmente "confusa", assim como aceitar a mudança. Ex: fica muito } \\
\text { agitada quando é levada a uma padaria diferente/ o caminho para a escola é } \\
\text { mudado, mas acalma-se facilmente. }\end{array}$ \\
\hline \multicolumn{2}{|l|}{2,5} \\
\hline 3 & $\begin{array}{l}\text { Anormalidade Moderada: Há resistência a mudanças de rotina. Há uma } \\
\text { tentativa de persistir na atividade costumeira e é difícil acalmá-la: ficam } \\
\text { raivosos ou tristes quando há modificação. }\end{array}$ \\
\hline \multicolumn{2}{|l|}{3,5} \\
\hline 4 & $\begin{array}{l}\text { Anormalidade Grave: Quando ocorrem mudanças, a criança apresenta reações } \\
\text { graves, que são difíceis de serem eliminadas. Se são forçadas a modificarem a } \\
\text { rotina, podem ficar extremamente irritadas/raivosas ou não cooperativas e } \\
\text { talvez respondam com birras. }\end{array}$ \\
\hline
\end{tabular}

\begin{tabular}{|l|l|}
\hline 7- USO DO OLHAR \\
\hline Pontos & Sintomas \\
\hline 1 & $\begin{array}{l}\text { Sem Anormalidade: O uso do olhar é normal para a idade. A visão é usada } \\
\text { junto com os outros sentidos, como a audição e o tato, como forma de explorar } \\
\text { os objetos. }\end{array}$ \\
\hline 1,5 & $\begin{array}{l}\text { Anormalidade Leve: A criança precisa ser lembrada de vez em quando para } \\
\text { olhar para os objetos. A criança pode estar mais interessada em olhar para } \\
\text { espelhos e luzes que outras crianças da mesma idade, ou ficar olhando para o } \\
\text { espaço de forma vaga. Pode haver evitação do olhar. }\end{array}$ \\
\hline 2
\end{tabular}




\begin{tabular}{|l|l|}
\hline 2,5 & $\begin{array}{l}\text { Anormalidade Moderada: A criança precisa ser lembrada a olhar o que está } \\
\text { fazendo. Podem ficar olhando para o espaço de forma vaga; evitação do olhar; } \\
\text { olhar para objetos de modo peculiar; colocar objetos muito próximos aos olhos } \\
\text { apesar de não terem déficit visual. }\end{array}$ \\
\hline 3,5 & $\begin{array}{l}\text { Anormalidade Grave: Há uma persistente recusa em olhar para pessoas ou } \\
\text { certos objetos e podem apresentar outras peculiaridades no uso do olhar em } \\
\text { graus extremos como os descritos acima. }\end{array}$ \\
\hline 4 &
\end{tabular}




\begin{tabular}{|c|c|}
\hline \multicolumn{2}{|c|}{ 8- USO DA AUDIÇÃO } \\
\hline Pontos & Sintomas \\
\hline 1 & $\begin{array}{l}\text { Sem Anormalidade: O uso da audição é normal para a idade. A audição é usada } \\
\text { junto com os outros sentidos, como a visão e o tato. }\end{array}$ \\
\hline \multicolumn{2}{|l|}{1,5} \\
\hline 2 & $\begin{array}{l}\text { Anormalidade Leve: Pode haver falta de resposta a certos sons, assim como } \\
\text { uma hiper-reatividade. Às vezes, a reação é atrasada; às vezes, é necessário a } \\
\text { repetição de um determinado som para "ativar" a atenção da criança. A criança } \\
\text { pode apresentar uma resposta catastrófica a sons estranhos a ela. }\end{array}$ \\
\hline \multicolumn{2}{|l|}{2,5} \\
\hline 3 & $\begin{array}{l}\text { Anormalidade Moderada: A resposta aos sons pode variar: ignorá-los das } \\
\text { primeiras vezes, ficar assustado com sons de seu cotidiano, tampar os ouvidos. }\end{array}$ \\
\hline \multicolumn{2}{|l|}{3,5} \\
\hline 4 & $\begin{array}{l}\text { Anormalidade Grave: Há uma sub- ou hiper-reatividade aos sons, de uma } \\
\text { forma extremada, independentemente do tipo de som. }\end{array}$ \\
\hline
\end{tabular}

\begin{tabular}{|l|l|}
\hline 9- USO DO PALADAR, OLFATO E TATO \\
\hline Pontos & Sintomas \\
\hline 1 & $\begin{array}{l}\text { Sem Anormalidade: A criança explora novos objetos de acordo com a idade, } \\
\text { geralmente através dos sentidos. O paladar e o olfato são usados } \\
\text { apropriadamente quando o objeto é percebido como comível. Quando há dor } \\
\text { resultante de batida, queda ou pequenos machucados, a criança expressa seu } \\
\text { desconforto, mas sem uma reação desmedida. }\end{array}$ \\
\hline 1,5 & $\begin{array}{l}\text { Anormalidade Leve: A criança persiste no levar e manter objetos na boca, em } \\
\text { discrepância de outras da mesma idade. Pode cheirar ou colocar na boca, de } \\
\text { vez em quando, objetos não comestíveis. A criança pode ignorar ou reagir de } \\
\text { forma exacerbada a um beliscão ou alguma dor leve que numa criança normal } \\
\text { seria expressa de forma adequada (leve). }\end{array}$ \\
\hline 2,5 & \\
\hline
\end{tabular}




\begin{tabular}{|l|l|}
\hline 3 & $\begin{array}{l}\text { Anormalidade Moderada: Pode haver um comportamento de grau moderado de } \\
\text { tocar, cheirar, lamber objetos ou pessoas. Pode haver uma reação não habitual } \\
\text { à dor em grau moderado, assim como sub- ou hiper-reação. }\end{array}$ \\
\hline 3,5 & $\begin{array}{l}\text { Anormalidade Grave: Há um comportamento de cheirar, colocar na boca, ou } \\
\text { pegar objetos - pela sensação em si - sem o objetivo de exploração do objeto. } \\
\text { Pode haver uma completa falta de resposta à dor, assim como uma hiper-reação } \\
\text { a algo que é só levemente desconfortável. }\end{array}$ \\
\hline 4
\end{tabular}




\begin{tabular}{|c|c|}
\hline $10-\mathrm{N}$ & NERVOSISMO \\
\hline Pontos & Sintomas \\
\hline 1 & $\begin{array}{l}\text { Sem Anormalidade: O comportamento é apropriado à idade e situação da } \\
\text { criança. }\end{array}$ \\
\hline 1,5 & \\
\hline 2 & $\begin{array}{l}\text { Anormalidade Leve: De vez em quando a criança demonstra medo e } \\
\text { nervosismo que é levemente inapropriado (para mais ou menos) quando } \\
\text { comparado a outras de mesma idade. }\end{array}$ \\
\hline 2,5 & \\
\hline 3 & $\begin{array}{l}\text { Anormalidade Moderada: A criança apresenta um pouco mais ou um pouco } \\
\text { menos de medo que uma criança normal, mesmo quando comparada a outra de } \\
\text { menor idade colocada em situação idêntica. Pode ser difícil entender o que está } \\
\text { causando o comportamento de medo apresentado, assim como é difícil } \\
\text { confortá-la nesta situação. }\end{array}$ \\
\hline 3,5 & \\
\hline 4 & $\begin{array}{l}\text { Anormalidade Grave: Há manutenção do medo mesmo após repetidas } \\
\text { experiências de esperado bem-estar. Na consulta de avaliação a criança pode } \\
\text { estar amedrontada sem razão aparente. É extremamente difícil acalmá-la. Pode } \\
\text { também não apresentar medo/ sentido de auto-conservação a cachorros não } \\
\text { conhecidos, a riscos da rua e trânsito, como outras que as da mesma idade } \\
\text { evitam. }\end{array}$ \\
\hline
\end{tabular}

\begin{tabular}{|c|c|}
\hline \multicolumn{2}{|c|}{ 11- COMUNICAÇÃO VERBAL } \\
\hline Pontos & Sintomas \\
\hline 1 & Normal: Fala adequada para sua faixa etária. \\
\hline \multicolumn{2}{|l|}{1,5} \\
\hline 2 & $\begin{array}{l}\text { Anormalidade Leve: Atraso global da fala; conteúdo verbal significativo na } \\
\text { maior parte podendo, entretanto, existir ecolalia ou inversão pronominal em } \\
\text { relação ao esperado para sua idade. Usa algumas palavras peculiares e } \\
\text { ocasionalmente há jargonofasia. }\end{array}$ \\
\hline
\end{tabular}




\begin{tabular}{|l|l|}
\hline 2,5 & $\begin{array}{l}\text { Anormalidade Moderada: Eventualmente não fala. Quando presente a } \\
\text { comunicação verbal mi stura conteúdo significativo com fala peculiar, jargões, } \\
\text { comerciais de TV, jogo de futebol, reportagem sobre o tempo; ecolalia; } \\
\text { inversão pronominal. Mesmo quando tem significado, o discurso se caracteriza } \\
\text { por questionamentos em excesso e preocupações com tópicos específicos. }\end{array}$ \\
\hline 3,5 & $\begin{array}{l}\text { Anormalidade Grave: Não há fala significativa, a criança grunhe e emite sons } \\
\text { que lembram animais; pode até emitir sons mais complexos que se aproximam } \\
\text { da fala humana. Pode haver uso persistente, bizarro, de algumas palavras ou } \\
\text { frases. }\end{array}$ \\
\hline 4
\end{tabular}




\begin{tabular}{|l|l|}
\hline 12- COMUNICAÇÃO NÃO VERBAL \\
\hline Pontos & $\begin{array}{l}\text { Sintomas } \\
\text { Normal: Comunicação adequada para sua faixa etária e às situações. }\end{array}$ \\
\hline 1,5 & $\begin{array}{l}\text { Anormalidade Leve: Uso imaturo da comunicação não verbal, apontando ou } \\
\text { mostrando sem precisão o que quer, diferentemente de uma criança de sua } \\
\text { idade que aponta com maior precisão e usa gestos mais significativos. }\end{array}$ \\
\hline 2 & $\begin{array}{l}\text { Anormalidade Moderada: De regra a criança é incapaz de exprimir suas } \\
\text { necessidades e desejos através de gestos assim como também é incapaz de } \\
\text { entender os gestos dos outros. Agarram a mão dos adultos, levando-os ao } \\
\text { objeto desejado, sendo incapazes de mostrá-lo através de gestos. }\end{array}$ \\
\hline 3,5 & $\begin{array}{l}\text { Anormalidade Grave: Usa apenas gestos bizarros e peculiares sem significado } \\
\text { aparente. Parecem não conhecer o significado de gestos ou expressões faciais } \\
\text { de terceiros. }\end{array}$ \\
\hline 3,5
\end{tabular}

\begin{tabular}{|c|c|}
\hline \multicolumn{2}{|c|}{ 13- ATIVIDADE } \\
\hline Pontos & Sintomas \\
\hline 1 & Normal: Apropriada para a situação e para a idade cronológica. \\
\hline \multicolumn{2}{|l|}{1,5} \\
\hline 2 & $\begin{array}{l}\text { Anormalidade Leve: Pode existir alguma inquietude ou lentidão de } \\
\text { movimentos. Seu grau de atividade interfere de maneira leve na performance } \\
\text { da criança. É possível mantê-la com um nível de atividade adequado. }\end{array}$ \\
\hline \multicolumn{2}{|l|}{2,5} \\
\hline 3 & $\begin{array}{l}\text { Anormalidade Moderada: Apresenta-se inquieta e com dificuldades para ficar } \\
\text { quieta. Aparenta enorme energia, não querendo parar para dormir. Pode ainda } \\
\text { ser letárgica e exigir grandes esforços para modificar esse comportamento. } \\
\text { Costumam evitar jogos que exijam atividade física, passando por } \\
\text { "preguiçosos". }\end{array}$ \\
\hline
\end{tabular}




\begin{tabular}{|l|l|}
\hline 3,5 & \\
\hline 4 & $\begin{array}{l}\text { Anormalidade Grave: Níveis de atividades extremas variando do hiper ao hipo } \\
\text { e c/ facilidade em passar de um a outro nível. Difícil de manipular. A } \\
\text { hiperatividade, quando presente, manifesta-se em todas as atividades do } \\
\text { cotidiano, exigindo acompanhamento contínuo. Se hipoativa, é difícil motivá- } \\
\text { la para qualquer coisa. }\end{array}$ \\
\hline
\end{tabular}




\begin{tabular}{|c|c|}
\hline \multicolumn{2}{|c|}{ 14- GRAU E CONSISTÊNCIA DAS RESPOSTAS DA INTELIGÊNCIA } \\
\hline Pontos & Sintomas \\
\hline 1 & $\begin{array}{l}\text { Normal: A criança é inteligente, como qualquer criança normal de sua idade, } \\
\text { não se detectando inabilidades ou problemas. }\end{array}$ \\
\hline \multicolumn{2}{|l|}{1,5} \\
\hline 2 & $\begin{array}{l}\text { Anormalidade Leve: A criança não é tão inteligente como outra de sua idade e, } \\
\text { quanto às suas habilidades, apresenta atraso global e homogêneo em todas as } \\
\text { áreas. }\end{array}$ \\
\hline \multicolumn{2}{|l|}{2,5} \\
\hline 3 & $\begin{array}{l}\text { Anormalidade Moderada: De regra é uma criança não tão inteligente quanto os } \\
\text { de sua idade porém, em algumas áreas, seu desempenho intelectual situa-se } \\
\text { próximo ao normal. }\end{array}$ \\
\hline \multicolumn{2}{|l|}{3,5} \\
\hline 4 & $\begin{array}{l}\text { Anormalidade Grave: mesmo com uma inteligência inferior ao de uma criança } \\
\text { normal destaca-se, até mesmo com bom desempenho, em algumas áreas, como } \\
\text { por ex. : talento p/ música, facilidade com números. }\end{array}$ \\
\hline
\end{tabular}

\begin{tabular}{|l|l|}
\hline $15-$ IMPRESS ÃO GERAL \\
\hline Pontos & Sintomas \\
\hline 1 & $\begin{array}{l}\text { Não há autismo. A criança não apresentou nenhum sintoma característico de } \\
\text { autismo. }\end{array}$ \\
\hline 1,5 & \\
\hline 2 & Autismo Leve: alguns, poucos, sintomas ou grau leve de autismo. \\
\hline 2,5 & Autismo Moderado : vários sintomas de autismo. \\
\hline 3 & \\
\hline 3,5 & Autismo Grave: muitos sintomas de autismo. \\
\hline 4 &
\end{tabular}




\section{Escala de Traços Autísticos}

\section{ESCALA DE TRAÇOS AUTÍSTICOS}

\section{DIFICULDADE NA INTERAÇÃO SOCIAL}

O. desvio da sociabilidade pode oscilar entre formas leves como, por exemplo, um certo negativismo e a não aceitação do contato ocular, até formas mais graves, como um intenso isolamento.

1.Não sorri ; 2.Ausência de aproximações espontâneas; 3.Não busca companhia;

4. Busca constantemente seu cantinho (esconderijo); 5.Evita pessoas; 6.É incapaz de manter um intercâmbio social; 7.Isolamento intenso

\section{MANIPULAÇÃO DO AMBIENTE}

O problema da manipulação do ambiente pode apresentar-se a nível mais ou menos grave, como, por exemplo, não responder às solicitações e manter-se indiferente ao ambiente. $O$ fato mais comum é a manifestação brusca de crises de birra passageira, risos incontroláveis e sem motivo, tudo isso com o fim de conseguir ser o centro da atenção

1. Não responde às solicitações; 2. Mudança repentina de humor; 3.Mantém-se indiferente, sem expressão; 4. Risos compulsivos; 5. Birra e raiva passageira; 6.Excitação motora ou verbal (ir de um lugar a outro, falar sem parar)

\section{UTILIZAÇÃO DAS PESSOAS A SEU REDOR}

A relação que mantém com o adulto quase nunca é interativa, dado que normalmente utiliza-se do adulto como o meio para conseguir o que deseja. 
1. Utiliza-se do adulto como um objeto, levando-o até aquilo que ele deseja; 2.0 adulto the serve como apoio para conseguir o que deseja (p.ex.: utiliza o adulto como apoio para pegar bolacha); 3.0 adulto é o meio para suprir uma necessidade que não é capaz de realizar só ( p.ex.: amarrar sapatos); 4 . Se o adulto não responde as suas demandas, atua interferindo na conduta desse adulto.

\section{RESISTÊNCIA À MUDANÇA}

A resistência à mudança pode variar da irritabilidade até a franca recusa.

1. Insistente em manter a rotina; 2.Grande dificuldade em aceitar fatos que alteram sua rotina, tais como mudanças de lugar, de vestuário e na alimentação; 3.Apresenta resistência a mudanças, persistindo na mesma resposta ou atividade

\section{BUSCA DE UMA ORDEM RÍGIDA}

Manifesta tendência a ordenar tudo, podendo chegar a uma conduta de ordem obsessiva, sem a qual não consegue desenvolver nenhuma atividade.

1. Ordenação dos objetos de acordo com critérios próprios e pré-estabelecidos; 2.Prende-se a uma ordenação espacial (Cada coisa sempre em seu lugar); 3.Prende-se a uma seqüência temporal (Cada coisa em seu tempo); 4.Prendese a uma correspondência pessoa-lugar (Cada pessoa sempre no lugar determinado)

\section{FALTA DE CONTATO VISUAL. OLHAR INDEFENIDO}

A falta de contato pode variar desde um olhar estranho até o constante evitar dos estímulos visuais 
1. Desvia os olhares diretos, não olhando nos olhos; 2.Volta a cabeça ou o olhar quando é chamado (olhar para fora); 3.Expressão do olhar vazio e sem vida; 4.Quando segue os estímulos com os olhos, somente o faz de maneira intermitente; 5. Fixa os objetos com uma olhada periférica, não central; 6.Dá a sensação de que não olha

\section{MÍMICA INEXPRESSIVA}

A inexpressividade mímica revela a carência da comunicação não verbal. Pode apresentar desde uma certa expressividade até uma ausência total de resposta.

1. Se fala, não utiliza a expressão facial, gestual ou vocal com a freqüência esperada; 2.Não mostra uma reação antecipatória; 3.Não expressa através da mímica ou olhar aquilo que quer ou o que sente; 4.Imobilidade facial

\section{DISTÚRBIOS DE SONO}

Quando pequeno dorme muitas horas e, quando maior, dorme poucas horas, se comparado ao padrão esperado para a idade. Esta conduta pode ser constante, ou não.

1. Não quer ir dormir; 2.Se levanta muito cedo; 3.Sono irregular (em intervalos); 4.Troca ou dia pela noite; 5.Dorme muito poucas horas.

\section{ALTERAÇÃO NA ALIMENTAÇÃO}

Pode ser quantitativa e/ou qualitativa. Pode incluir situações, desde aquela em que a criança deixa de se alimentar até aquela em que se opõe ativamente.

1. Seletividade alimentar rígida (ex.: come o mesmo tipo de alimento sempre); 2.Come outras coisas além de alimentos (papel, insetos); 3.Quando pequeno não mastigava; 4.Apresenta uma atividade ruminante; 5.Vômitos; 6.Come grosseiramente, esparrama a comida ou a atira; 7.Rituais ( esfarela alimentos antes da ingestão); 8.Ausência da paladar (Falta de sensibilidade gustativa) 


\section{DIFICULDADE NO CONTROLE DOS ESFÍNCTERES}

O controle dos esfíncteres pode existir, porém a sua utilização pode ser uma forma de manipular ou chamar a atenção do adulto.

1. Medo de sentar-se no vaso sanitário; 2.Utiliza os esfíncteres para manipular o adulto; 3.Utiliza os esfíncteres como estimulação corporal, para obtenção de prazer; 4.Tem controle diurno, porém o noturno é tardio ou ausente

\section{EXPLORAÇÃO DOS OBJETOS (APALPAR, CHUPAR)}

Analisa os objetos sensorialmente, requisitando mais os outros órgãos dos sentidos em detrimento da visão, porém sem uma finalidade específica

1. Morde e engole objetos não alimentares; 2.Chupa e coloca as coisas na boca; 3.Cheira tudo; 4.Apalpa tudo. Examina as superfícies com os dedos de uma maneira minuciosa

\section{USO INAPROPRIADO DOS OBJETOS}

Não utiliza os objetos de modo funcional, mas sim de uma forma bizarra.

1. Ignora os objetos ou mostra um interesse momentâneo; 2.Pega, golpeia ou simplesmente os atira no chão; 3.Conduta atípica com os objetos (segura indiferentemente nas mãos ou gira); 4.Carrega insistentemente consigo determinado objeto; 5 .Se interessa somente por uma parte do objeto ou do brinquedo; 6.Coleciona objetos estranhos; 7.Utiliza os objetos de forma particular e inadequada 


\section{FALTA DE ATENÇÃO}

Dificuldades na fixação e concentração. Às vezes, fixa a atenção em suas próprias produções sonoras ou motoras, dando a sensação de que se encontra ausente.

1. Quando realiza uma atividade, fixa a atenção por curto espaço de tempo ou é incapaz de fixá-la; 2.Age como se fosse surdo; 3.Tempo de latência de resposta aumentado; 4.Entende as instruções com dificuldade (quando não the interessa, não as entende); 5.Resposta retardada; 6.Muitas vezes dá a sensação de ausência

\section{AUSÊNCIA DE INTERESSE PELA APRENDIZAGEM}

Não tem nenhum interesse por aprender, buscando solução nos demais. Aprender representa um esforço de atenção e de intercâmbio pessoal, é uma ruptura em sua rotina.

1. Não quer aprender; 2.Se cansa muito depressa, ainda que em atividade que goste; 3.Esquece rapidamente; 4.Insiste em ser ajudado, ainda que saiba fazer; 5.Insiste constantemente em mudar de atividade

\section{FALTA DE INICIATIVA}

Busca constantemente a comodidade e espera que lhe dêem tudo pronto. Não realiza nenhuma atividade funcional por iniciativa própria.

1. É incapaz de ter iniciativa própria; 2.Busca a comodidade; 3.Passividade, falta de interesse; 4.Lentidão; 5.Prefere que outro faça o trabalho para ele

\section{ALTERAÇÃO DE LINGUAGEM E COMUNICAÇÃO}

É uma característica fundamental do autismo, que pode variar desde um atraso de linguagem até formas mais severas, com uso exclusivo de fala particular e estranha. 
1. Mutismo; 2.Estereotipias vocais; 3.Entonação incorreta; 4.Ecolalia imediata e/ou retardada; 5.Repetição de palavras ou frases que podem ou não ter valor comunicativo; 6.Emite sons estereotipados quando está agitado e em outras ocasiões, sem nenhuma razão aparente; 7.Não se comunica por gestos; 8.As interações com adulto não são nunca um diálogo

\section{NÃO MANIFESTA HABILIDADES E CONHECIMENTOS}

Nunca manifesta tudo aquilo que é capaz de fazer ou agir, no que faz referência a seus conhecimentos e habilidades, dificultando a avaliação dos profissionais.

1. Ainda que saiba fazer uma coisa, não a realiza, se não quiser; 2.Não demonstra o que sabe até que tenha uma necessidade primária ou um interesse iminentemente específico; 3.Aprende coisas, porém somente a demonstra em determinados lugares e com determinadas pessoas; 4.As vezes surpreende por suas habilidades inesperadas

\section{REAÇÕES INAPROPRIADAS ANTE A FRUSTRAÇÃO}

Manifesta desde o aborrecimento à reação de cólera, ante a frustração.

1. Reações de desagrado caso seja esquecida alguma coisa; 2.Reações de desagrado caso seja interrompida alguma atividade que goste; 3.Desgostoso quando os desejos e as expectativas não se cumprem; 4. Reações de birra

\section{NÃO ASSUME RESPONSABILIDADES}

Por princípio, é incapaz de fazer-se responsável, necessitando de ordens sucessivas para realizar algo.

1. Não assume nenhuma responsabilidade, por menor que seja; 2.Para chegar a fazer alguma coisa, há que se repetir muitas vezes ou elevar o tom de voz 


\section{HIPERATIVIDADE/ HIPOATIVIDADE}

A criança pode apresentar desde agitação, excitação desordenada e incontrolada, até grande passividade, com ausência total de resposta. Estes comportamentos não tem nenhuma finalidade.

1. A criança está constantemente em movimento; 2.Mesmo estimulada, não se move; 3.Barulhento. Dá a sensação de que é obrigado a fazer ruído/barulho; 4.Vai de um lugar a outro, sem parar; 5.Fica pulando (saltando) no mesmo lugar; 6.Não se move nunca do lugar onde está sentado

\section{MOVIMENTOS ESTEREOTIPADOS E REPETITIVOS}

Ocorrem em situações de repouso ou atividade, com início repentino.

1. Balanceia-se; 2.Olha e brinca com as mãos e os dedos; 3.Tapa os olhos e as orelhas; 4.Dá pontapés; 5.Faz caretas e movimentos estranhos com a face; 6.Roda objetos ou sobre si mesmo; 7.Caminha na ponta dos pés ou saltando, arrasta os pés, anda fazendo movimentos estranhos; 8.Torce o corpo, mantém uma postura desequilibrada, pernas dobradas, cabeça recolhida aos pés, extensões violentas do corpo

\section{IGNORA O PERIGO}

Expõe-se sem ter consciência do perigo

1.Não se dá conta do perigo; 2.Sobe em todos os lugares; 3.Parece insensível a dor

XXIII. APARECIMENTO ANTES DOS 36 MESES (DSM-IV) 


\title{
Escala de funcionamento global para crianças
}

\author{
ESCALA DE AVALIAÇÃO GLOBAL DE CRIANÇAS \\ (CHFLDREN'S GLOBAL ASSESSMENT SCALE - CGAS) \\ (para crianças de 4 a 16 anos de idade)
}

Pontue o nível de maior limitação da criança em seu funcionamento geral para o período de tempo especificado,selecionando o nível mais baixo que descreva seu funcionamento em um continuum hipotético de saúde-doença. Use níveis intermediários (p.cx., 35, 58, 62).

Pontue o funcionamento real independente do tratamento ou prognóstico. Os exemplos de comportamentos fornecidos são somente ilustrativos e não são necessários para uma pontuação particular.

100-91 Funcionamento superior $\mathrm{cm}$ todas as áreas (em casa, na escola e com os pares); envolvido numa ampla gama de atividades e tem muitos interesses (p.ex., tem hobbies ou participa em atividades extracurriculares ou pertence a um grupo organizado, como time de futebol, escotismo, entre outros); amável, seguro, as preocupações do dia-a-dia nunca saem de seu controle; vai bem na escola; sem sintomas.

90-81 Bom funcionamento em todas as áreas; sente-se seguro em família, na escola e com os pares; pode haver dificuldades passageiras, e, ocasionalmente, as preocupações do dia-a-dia saem de seu controle; (p.ex., ansiedade discreta associada com um exame importante, acessos de raiva ocasionais com irmãos, pais ou com os pares).

80-71 Não mais que uma limitação leve no funcionamento em casa, na escola ou com os pares; algum distúrbio no comportamento ou desconforto emocional pode estar presente em resposta a situações de estresse na vida (separação dos pais, falecimento, nascimento de um irmão), mas são breves, e a interferência no funcionamento é passageira: outras crianças são só, minimamente, perturbadas por tais crianças e não são consideradas desviantes por aqueles que as conhecem. .

70-61 Alguma dificuldade em uma única área, mas, em geral, funciona relativamente bem (p.ex., atos antisociais isolados ou esporádicos tais como: ocasionalmente cabulalmata aula ou comete furto insignificante; dificuldades menores persistentes no trabalho escolar; alterações no humor, de curta duração; medos e ansiedades que não conduzem a um sério comportamento de evitação; inseguro); tem algumas relações interpessoais importantes; a maioria das pessoas que não 
conhece bem a criança não a considerariam desviante, mas aqueles que a conhecem bem poderiam expressar preocupação.

60-51 Funcionamento variável com dificuldades esporádicas ou sintomas em várias, mas não em todas áreas Sociais; o problema seria aparente para aqueles que encontram a criança em uma situação disfuncional no momento mas não para aqueles que vêem a criança em outras situações.

50-41 Grau moderado de interferência no funcionamento na maioria das áreas sociais, limitação grave do funcionamento em uma área, que pode resultar, por exemplo, de preocupações e ruminações suicidas, recusa escolar e outras formas de ansiedade, rituais obsessivos, sintomas importantes de conversão, crises freqüientes de ansiedade, habilidades sociais pobres ou inapropriadas, episódios freqüentes de comportamento agressivo ou outros comportamentos antisociais com alguma preservação das relações sociais significativas.

40-31 Limitação importante no funcionamento em várias áreas e incapaz de funcionar em uma dessas áreas, ou seja, perturbado em casa, na escola, com os pares ou na sociedade de modo geral, p. ex., agressão constante sem uma provocação evidente; comportamento isolado e retraimento acentuado, por distúrbio do humor ou do pensamento. Tentativas de suicídio com intenção claramente letal; tais crianças provavelmente requerem escola especial e/ou hospitalização ou retirada da escola (mas isto não é um critério suficiente para a inclusão nesta categoria).

30-21 Incapaz de funcionar em quase todas as áreas, p. ex., permanece em casa, na enfermaria ou na cama o dia todo sem tomar parte nas atividades sociais ou grave limitação na noção de realidade ou séria limitação na comunicação (p.ex..às vezes inapropriada ou incoerente).

20-11 Necessita considerável supervisão para prevenir que machuque a si mesmo ou a outros (p.ex., é violento com freqüência, faz tentativas repetidas de suicídio) ou para manter a higiene pessoal, ou grave limitação em todas formas de comunicação, p. cx., anormalidades graves na comunicação verbal ou gestual, alhearnento social acentuado, estupor, etc.

10-1 Necessita supervisão constante ( 24 hs de cuidado) devido a comportamento agressivo grave ou autodestrutivo ou grande limitação no teste de realidade, comunicação, cognição, afeto ou higiene pessoal. 